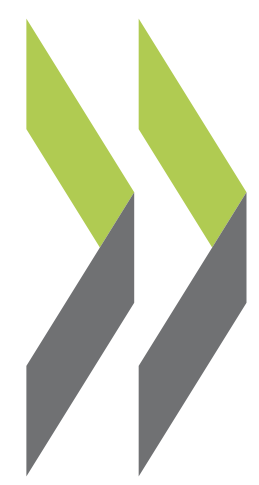

OECD Economics Department Working Papers No. 1261

\author{
Enhancing Dynamism \\ and Innovation in Japan's \\ Business Sector
}

Randall S. Jones, Myungkyoo Kim 
Organisation de Coopération et de Développement Économiques

Organisation for Economic Co-operation and Development

02-Sep-2015

ECONOMICS DEPARTMENT

English - Or. English

\section{ENHANCING DYNAMISM AND INNOVATION IN JAPAN'S BUSINESS SECTOR}

ECONOMICS DEPARTMENT WORKING PAPERS No. 1261

By Randall S. Jones and Myungkyoo Kim

OECD Working Papers should not be reported as representing the official views of the OECD or of its member countries. The opinions expressed and arguments employed are those of the author(s).

Authorised for publication by Robert Ford, Deputy Director, Country Studies Branch, Economics Department.

Document available in pdf format only.

All Economics Department Working Papers are available at www.oecd.org/eco/workingpapers

JT03381194

Complete document available on OLIS in its original format

This document and any map included herein are without prejudice to the status of or sovereignty over any territory, to the delimitation of international frontiers and boundaries and to the name of any territory, city or area. 
OECD Working Papers should not be reported as representing the official views of the OECD or of its member countries. The opinions expressed and arguments employed are those of the author(s).

Working Papers describe preliminary results or research in progress by the author(s) and are published to stimulate discussion on a broad range of issues on which the OECD works.

Comments on Working Papers are welcomed, and may be sent to the Economics Department, OECD, 2 rue André-Pascal, 75775 Paris Cedex 16, France, or by e-mail to eco.contact@oecd.org.

All Economics Department Working Papers are available at www.oecd.org/eco/workingpapers.

The statistical data for Israel are supplied by and under the responsibility of the relevant Israeli authorities. The use of such data by the OECD is without prejudice to the status of the Golan Heights, East Jerusalem and Israeli settlements in the West Bank under the terms of international law.

\section{(C) OECD (2015)}

You can copy, download or print OECD content for your own use, and you can include excerpts from OECD publications, databases and multimedia products in your own documents, presentations, blogs, websites and teaching materials, provided that suitable acknowledgment of OECD as source and copyright owner is given. All requests for commercial use and translation rights should be submitted to rights@oecd.org 


\section{ABSTRACT/RÉSUMÉ \\ Enhancing dynamism and innovation in Japan's business sector}

Innovation is key to boosting economic growth in the face of a rapidly ageing population. While Japan spends heavily on education and $R \& D$, appropriate framework conditions are essential to increase the return on such investments by strengthening competition, both domestic and international, and improving resource allocation. Upgrading corporate governance would encourage firms to maximise profits and invest their large cash reserves. To promote open innovation in a global framework, it is necessary to improve universities and expand their role in business $R \& D$, while increasing international collaboration in R\&D from its current low level. Venture capital-backed firms and start-ups should play a key role in commercialising innovation. To make venture investment a growth driver, it is important to expand the role of business angels and foster entrepreneurship. SMEs, which account for $70 \%$ of employment, should contribute more to innovation.

This Working Paper relates to the 2015 OECD Economic Survey of Japan (www.oecd.org/eco/surveys/economic-survey-japan.htm) JEL classification: 013; 03; 038; 053.

Keywords: Japan, Abenomics, third arrow, Japan Revitalisation Strategy, productivity, knowledge-based capital, innovation, corporate governance, cash hoarding, product market regulation, terms of trade, agriculture, economic partnership agreements, FDI, R\&D, universities, venture capital, start-ups, SMEs.

\section{Renforcer le dynamisme et l'innovation dans le secteur des entreprises au Japon}

L'innovation est essentielle pour stimuler la croissance économique compte tenu du vieillissement rapide de la population. Le Japon consacre des dépenses considérables à l'enseignement et à la recherchedéveloppement (R-D), mais des conditions-cadre appropriées sont cruciales pour accroître le rendement de ces investissements en renforçant la concurrence, tant sur le plan interne qu'international, et en améliorant la répartition des ressources. Une modernisation de la gouvernance des entreprises les encouragerait à maximiser leurs bénéfices et à investir leurs amples réserves de trésorerie. Afin de promouvoir l'innovation ouverte dans un cadre mondial, il est nécessaire d'améliorer les universités et de renforcer leur rôle dans la R-D des entreprises, tout en développant la collaboration internationale en matière de R-D, qui est aujourd'hui limitée. Les entreprises financées par le capital-risque et les nouvelles entreprises devraient jouer un rôle clé dans la commercialisation de l'innovation. Pour faire de l'investissement en capital-risque un moteur de croissance, il est important de renforcer le rôle des investisseurs providentiels (business angels) et de favoriser l'entrepreneuriat. Les petites et moyennes entreprises (PME), qui représentent $70 \%$ de l'emploi, devraient contribuer davantage à l'innovation.

$\mathrm{Ce}$ Document de travail a trait à l'Étude économique de l'OCDE du Japon, 2015 (www.oecd.org/fr/eco/etudes/etude-economique-japon.htm ).

Classification JEL : 013; $03 ; 038 ; 053$.

Mots clés : Japon, Abenomics, troisième flèche, Stratégie de revitalisation du Japon, productivité, actifs intellectuels, innovation, gouvernance d'entreprise, accumulation d'espèces, réglementation des marchés de produits, termes de l'échange, agriculture, accords de partenariat économique, IDE, R-D, universités, capital-risque, jeunes entreprises, PME. 


\section{TABLE OF CONTENTS}

ENHANCING DYNAMISM AND INNOVATION IN JAPAN'S BUSINESS SECTOR ........................... 6

The challenge of achieving faster growth ......................................................................................... 7

Boosting labour productivity and enhancing Japan's competitiveness …....................................... 8

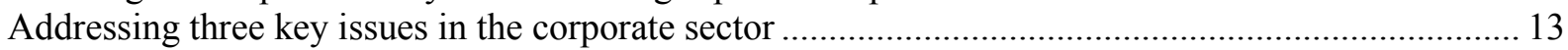

Framework conditions to promote innovation and boost productivity ............................................. 16

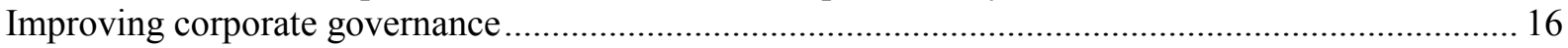

Labour market flexibility: relaxing employment protection........................................................... 20

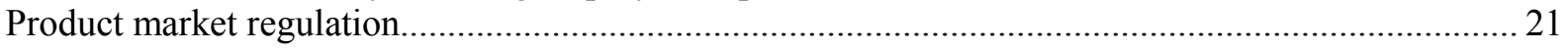

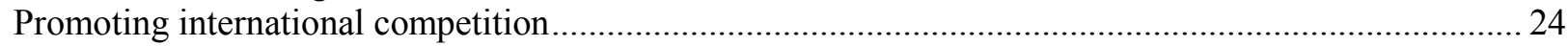

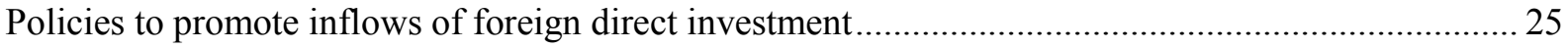

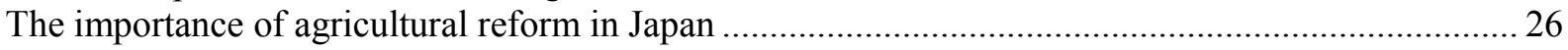

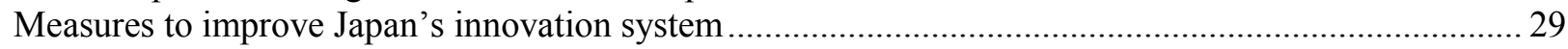

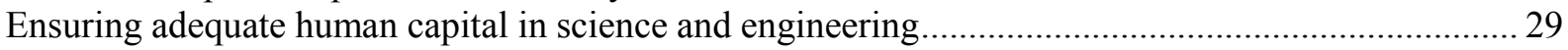

Upgrading the quality of universities and strengthening their links with firms in R\&D ......................30

Promoting open innovation in global networks and international collaboration ................................... 33

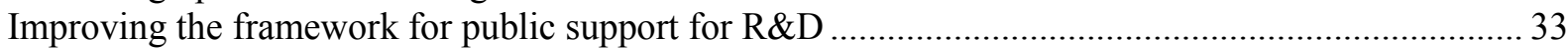

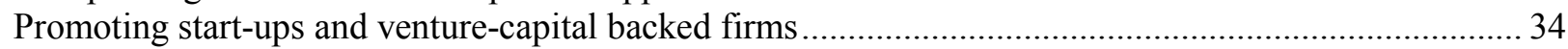

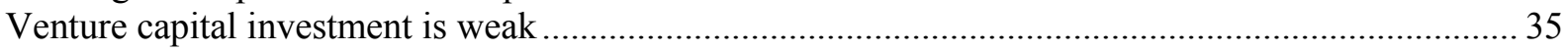

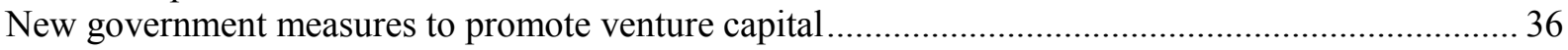

Policy directions to promote the venture business sector and start-ups.............................................. 38

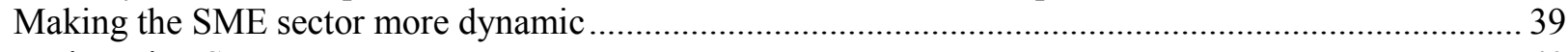

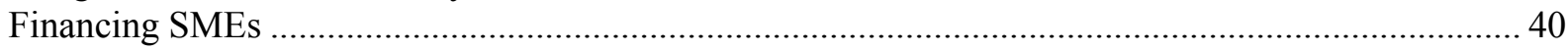

Problems associated with government intervention in SME financing ............................................... 42

Directions for reform to improve government programmes for SMEs ............................................. 45

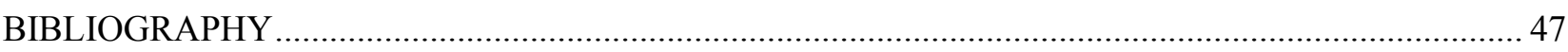

\section{Tables}

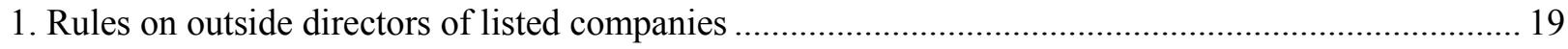

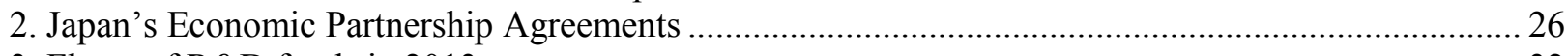

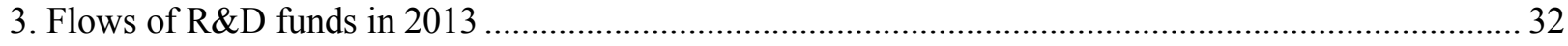

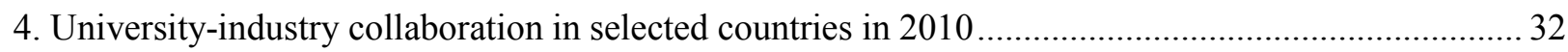

5. The share of SMEs relying on collateral and guarantees to receive loans .......................................... 43

\section{Figures}

1. Living standards in Japan are well below the top half of the OECD .................................................. 6

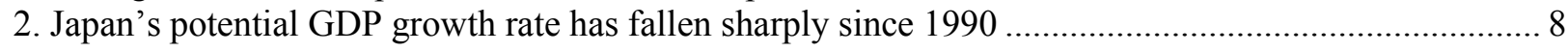

3. Average labour productivity growth in Japan is below the OECD average ....................................... 9

4. Japan's share of world exports has been falling during the past 20 years............................................. 9

5. Terms-of-trade losses are putting downward pressure on gross national income ................................. 10

6. Falling export prices are the key factor for Japan's terms-of-trade losses ......................................... 11

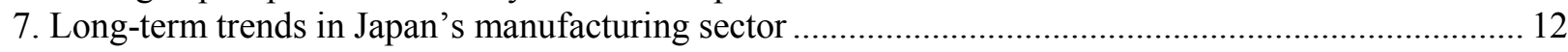




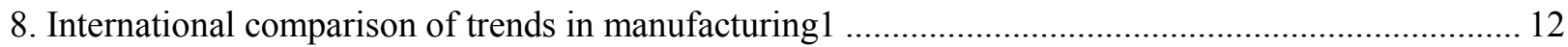

9. The productivity gap between manufacturing and non-manufacturing has widened sharply ............... 13

10. Japan's corporate sector has a saving surplus and large cash holdings ............................................. 13

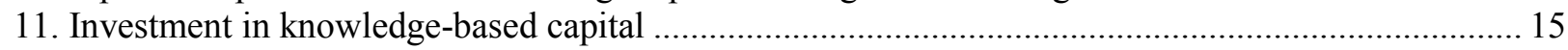

12. Return on assets have fallen, while return on equity is relatively low ............................................ 16

13. Shareholder composition of Japanese companies .......................................................................... 17

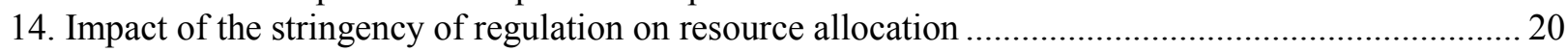

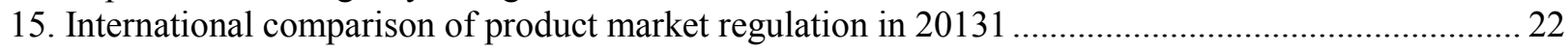

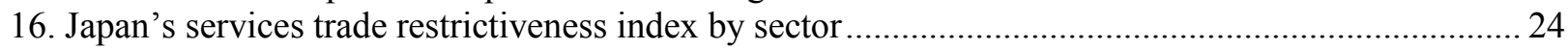

17. The Producer Support Estimate1 for Japan is the second highest in the OECD ............................... 27

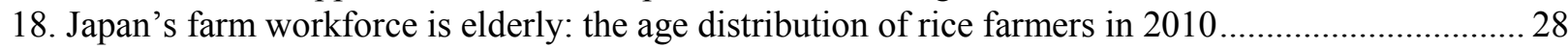

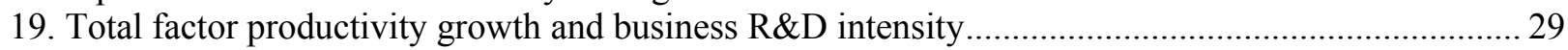

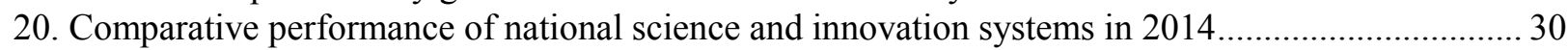

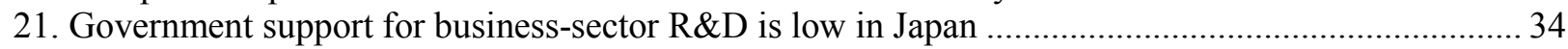

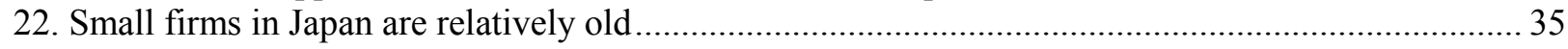

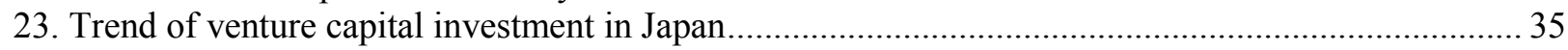

24. Venture capital investment as a share of GDP is relatively low in Japan ......................................... 36

25. Breakdown of investors in newly-established venture capital funds in Japan ................................... 37

26. Share of the population that views entrepreneurship as a good career choice is low in Japan ........... 37

27. School education does not provide the skills for entrepreneurship in Japan...................................... 38

28. Loans to small and medium-sized enterprises.................................................................................. 40

29. The framework of support for small and medium-sized enterprises ................................................ 41

30. Credit guarantees for SMEs in Japan are exceptionally high ...................................................... 42

31. The number of bankruptcies in Japan has fallen since 2008 despite two crises............................... 44

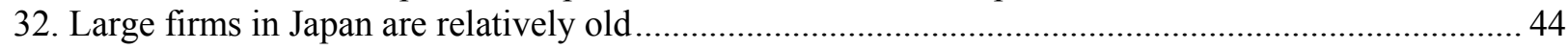

\section{Boxes}

Box 1. Reversing the terms-of-trade decline to boost purchasing power in Japan ................................. 10

Box 2. National Strategic Special Zones............................................................................................ 23

Box 3. Main policy recommendations to enhance dynamism and innovation in Japan's business sector 46 


\title{
ENHANCING DYNAMISM AND INNOVATION IN JAPAN'S BUSINESS SECTOR
}

\author{
By Randall S. Jones and Myungkyoo Kim ${ }^{1}$
}

Japan's income per capita, which matched the top half of the OECD countries in the early 1990s, fell to $83 \%$ in 2009 , before rebounding slightly (Figure 1). Japan's relative decline is linked to weaknesses in the business sector, reflected in Japan's falling share of world trade, declining terms of trade, low rates of return on capital and falling inflows of foreign direct investment. The government aims to double Japan's economic growth rate, which has averaged less than $1 \%$ per year since 1990 in real terms, to a $2 \%$ average through 2022. Given the shrinking population, this would imply $2.4 \%$ growth in per capita terms. Faster growth would boost living standards and help to put the public debt ratio, which has risen to $226 \%$ of GDP, on a downward trend (2015 OECD Economic Survey of Japan). Slower growth would require deeper spending cuts and higher taxes to achieve the target of a primary surplus in FY 2020, thus increasing headwinds to growth.

Figure 1. Living standards in Japan are well below the top half of the OECD

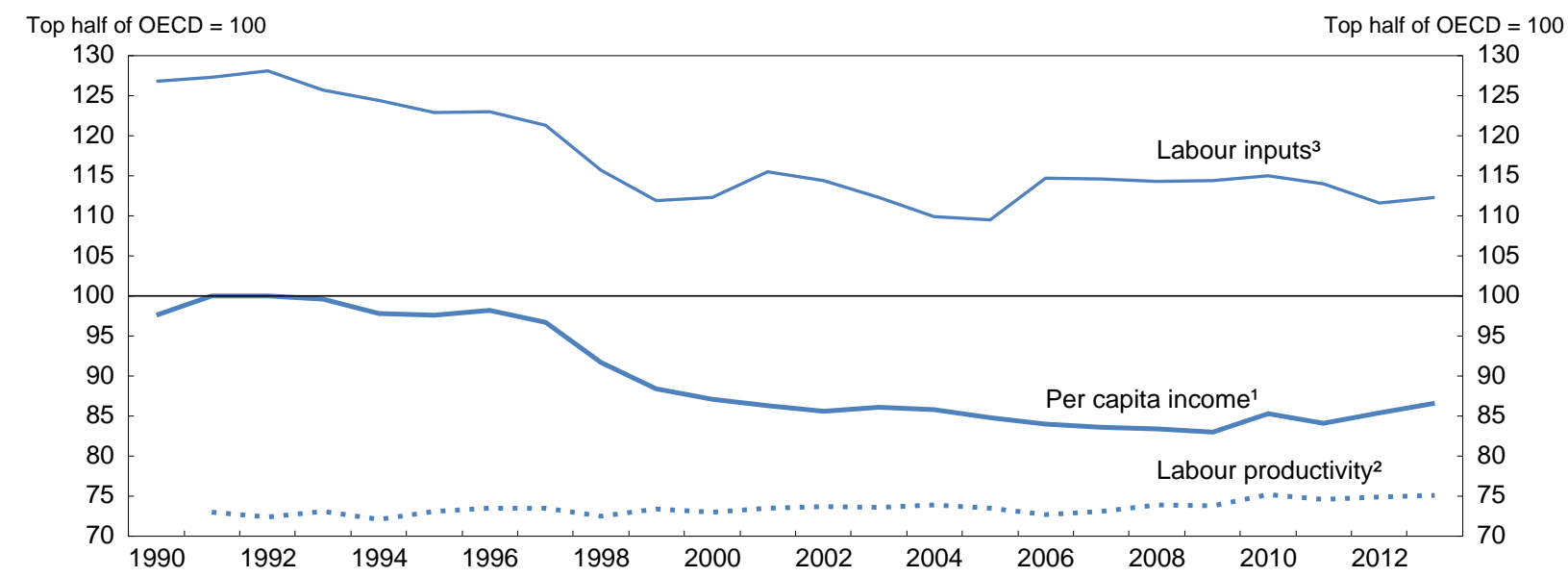

1. Per capita GDP using 2005 prices and PPP exchange rates.

2. GDP per hour of labour input.

3. Total number of hours worked per capita.

Source: OECD Going for Growth Database.

1. Randall S. Jones is head of the Japan/Korea Desk in the Economics Department of the OECD and Myungkyoo Kim was an economist on the Desk. This paper is based on material from the $O E C D$ Economic Survey of Japan published in April 2015 prior to the announcement of Japan's Basic Policy for Economic and Fiscal Policy Management at the end of June 2015. The Survey was released under the authority of the Economic and Development Review Committee (EDRC). The authors would like to thank the Japanese authorities, as well as Robert Ford, Kohei Fukawa, Gernot Hutschenreiter, Vincent Koen, Andrew McQueen, Akira Nozaki, Alvaro Pereira, Sebastian Schich, Miho Taguma and members of the EDRC for helpful comments and suggestions. Special thanks go to Lutécia Daniel for technical assistance and to Nadine Dufour and Mercedes Burgos for secretarial assistance. 
Achieving faster growth requires better utilising Japan's large stock of human and physical capital and its advanced technology. This depends, in turn, on reforms in a range of areas, many of which are addressed in the 2013 Industrial Competitiveness Enhancement Act, the legal basis for the Japan Revitalisation Strategy, the third arrow of Abenomics. The three major components of the Act include:

- Accelerated regulatory reform: two proposals are "corporate field tests", which allow flexibility in applying regulations to individual enterprises and "removing grey zones" by clarifying whether new products and services comply with existing regulations.

- The renovation of industries: i) encouraging investment in venture businesses; ii) promoting business restructuring through preferential tax and financial support for firms that wish to change their current structure; and iii) promoting investment in cutting-edge facilities using leases.

- Enhanced support for small and medium-sized enterprises (SMEs) to start and rehabilitate firms.

These priorities, as well as other policies to boost productivity and growth, are discussed below. After a review of the challenges facing Japan, the following section considers framework conditions, including corporate governance, labour market flexibility and product market regulations. Enhancing international competition is also important in this regard. These play a key role in determining the strength of competition and the flexibility of resource allocation. The fourth section provides an overview of the innovation framework. The following section examines policies to promote start-ups, including venture capital-backed businesses, which play a key role in commercialising new technology. The final section focuses on measures to boost innovation and productivity in SMEs. The agenda is broad and requires bold reforms that go well beyond the measures included in the Japan Revitalisation Strategy. In December 2014, the government stated that "Japan must aim to become the most innovative country in the world by carrying out social and economic structural changes". If the necessary reforms were easy, they would have been accomplished long ago. Policy recommendations are summarised in Box 3. The main findings include:

- Japan's competitiveness problems are reflected in its declining share of world trade, declining terms of trade, low rates of return on capital and falling inflows of foreign direct investment.

- Boosting output growth and narrowing the gap in per capita income levels relative to the top half of the OECD requires faster productivity gains, which depend on innovation.

- Increasing the return on Japan's high level of investment in R\&D and education requires creating an appropriate framework that strengthens competition and improves resource allocation.

- The innovation system is weakened by a lack of international collaboration and weak links between $\mathrm{R} \& \mathrm{D}$ in the business sector, academia and the government.

- The low rate of firm creation could be boosted by developing entrepreneurship and venture capital.

- The SME sector is lagging and needs to be revitalised so as to play a larger role in innovation.

\section{The challenge of achieving faster growth}

Achieving $2 \%$ real growth in Japan, where potential growth is currently estimated at around $3 / 4$ per cent by the OECD and less than $1 / 2$ per cent by the Bank of Japan (BoJ), is a daunting challenge. In the BoJ's 2015 public opinion survey, less than 3\% of respondents believe that the economy can grow faster than its current rate. Japan's potential growth rate has slowed from over 3\% in the early 1990s as a result of two factors: i) the working-age population (15-64) started falling in 1995, flipping the contribution of labour inputs from positive to negative; and ii) trend labour productivity has slowed significantly (Figure 2). Indeed, labour productivity per hour of labour input in Japan has remained around a quarter below the top half of OECD countries during the past 25 years (Figure 1). 
Figure 2. Japan's potential GDP growth rate has fallen sharply since 1990

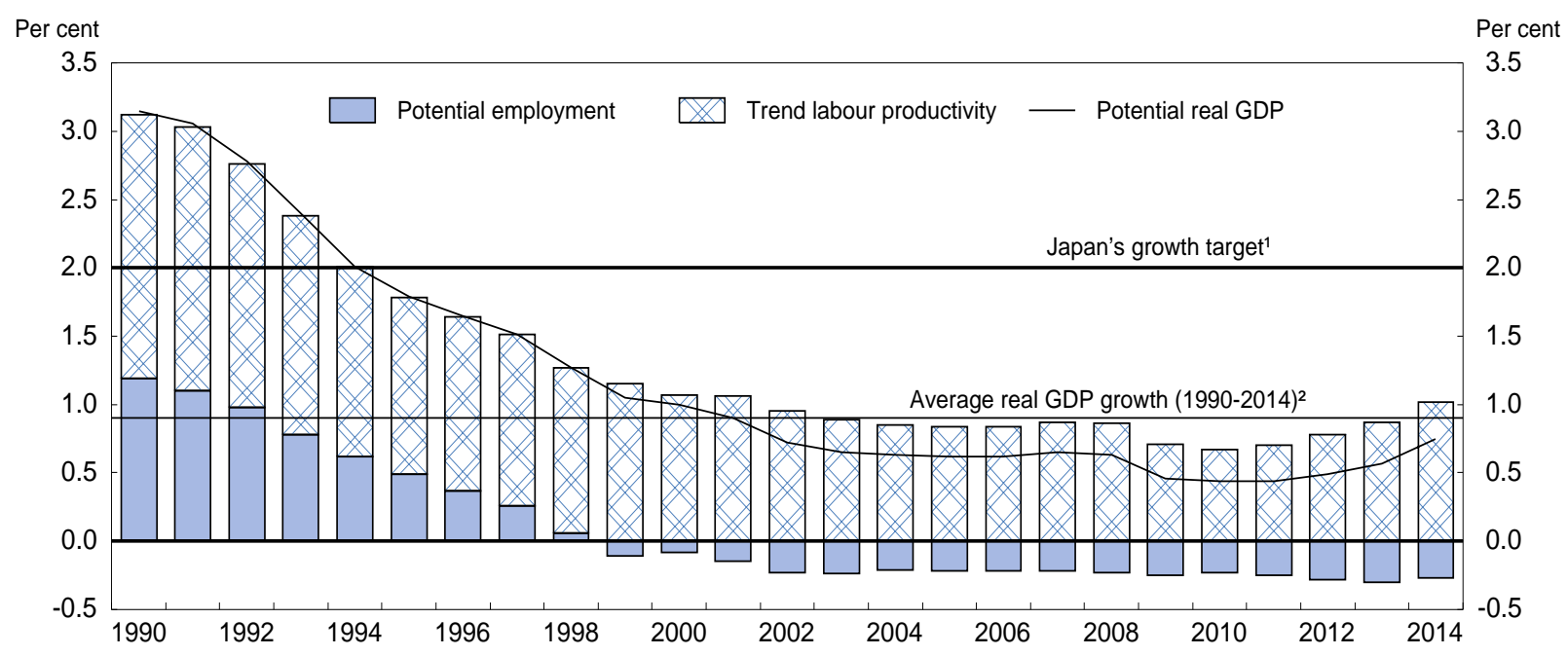

1. The $2 \%$ target was set in 2009 and maintained by subsequent governments.

2. Average annual GDP growth in real terms in Japan between 1990 and 2014.

Source: OECD Economic Outlook Database.

Looking ahead, Japan's growth potential faces downward pressure from population ageing, as the 1564 age group is declining at a rate of $1.5 \%$ per year. Measures to slow the fall in the labour force - or even reverse it - are thus crucial. Such policies should focus on increasing employment of women, older persons and youth, and making greater use of foreign workers. While there is still scope for expanding labour inputs, the employment rate for men is the third highest in the OECD, while that for women is already above the OECD average.

Even if labour inputs were stabilised, achieving the $2 \%$ growth target would require boosting labour productivity growth from its average rate of $0.9 \%$ since 2000 to $2 \%$ (Figure 3). Japan's labour productivity growth was below the OECD average of $1.2 \%$ over that period. Raising labour productivity growth to $2 \%$ is an extremely difficult challenge that is currently met by only a handful of OECD countries, notably emerging economies and central and eastern European countries.

\section{Boosting labour productivity and enhancing Japan's competitiveness}

Boosting labour productivity depends, in turn, on total factor productivity (TFP) growth, human capital accumulation and capital deepening. TFP offers the greatest scope for improvement, given that Japan already has a high level of human capital and one of the largest capital-output ratios in the OECD. In contrast, the contribution of TFP to trend labour productivity in Japan is only around 0.2 percentage points, well below the OECD average of 0.7 points. Wide and persistent differences in the level of TFP account for the bulk of the gaps in income per capita across countries (Andrews and Criscuolo, 2013). 
Figure 3. Average labour productivity growth in Japan is below the OECD average ${ }^{1}$ Average annual growth rate over 2000-13

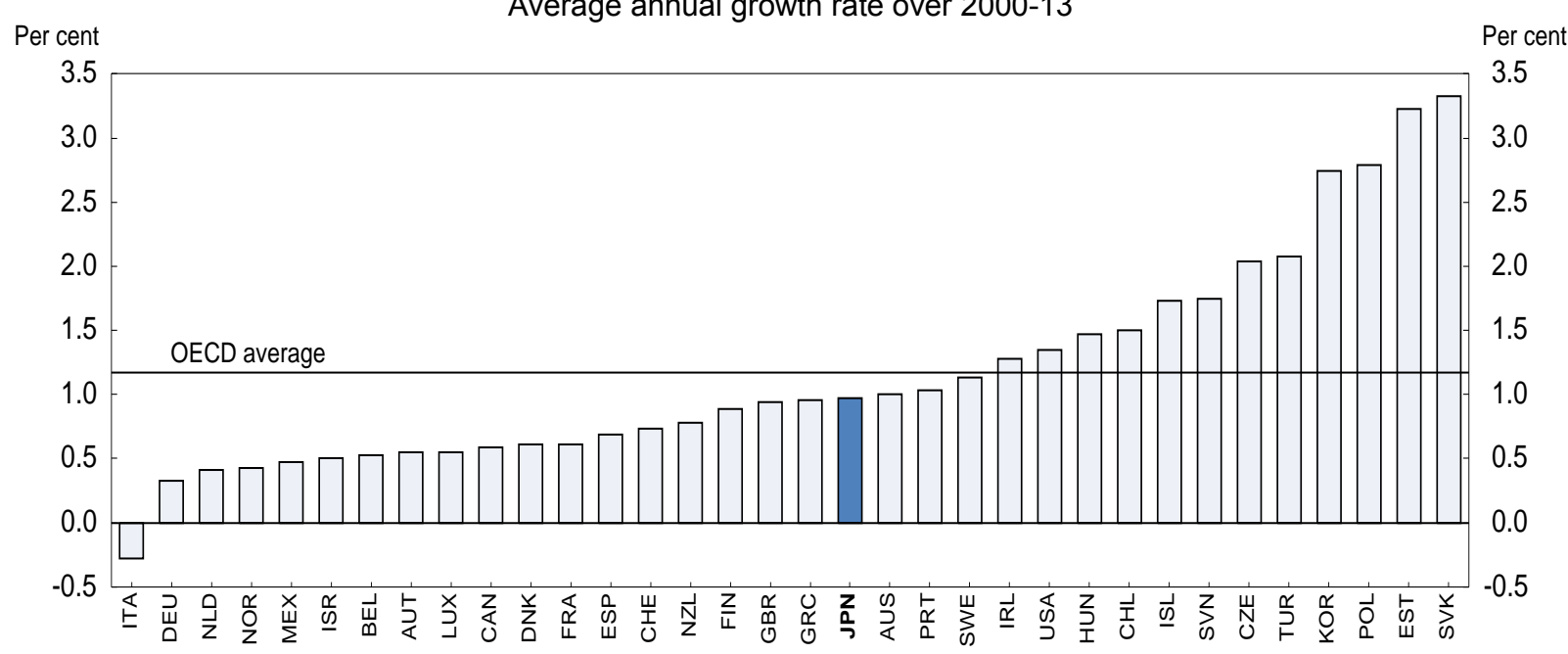

1. Real GDP divided by total employment (including self-employed).

Source: OECD Economic Outlook Database.

Weak productivity growth is reflected in international trade: during the past two decades, Japan's share of world exports fell from nearly $10 \%$ to only $4 \%$, while China's rose from $2.4 \%$ to nearly $12 \%$ (Figure 4). Competitiveness concerns have been reinforced by sluggish export growth despite the $30 \%$ decline in the real effective exchange rate since the third quarter of 2012. Meanwhile, Japan's share of high-tech exports from OECD countries fell from $22 \%$ in 1986 to $11 \%$ in 2009, while Korea's rose from less than $4 \%$ to $11 \%$. In addition, Japan has suffered persistent terms-of-trade losses in recent years that have reduced national income (Box 1). The deterioration in international competitiveness is symbolised by Japan's fall in the rankings of the International Institute for Management Development. After ranking first during the first five years of the survey (1989-93), Japan fell to $27^{\text {th }}$ out of 59 countries in 2012.

Figure 4. Japan's share of world exports has been falling during the past 20 years

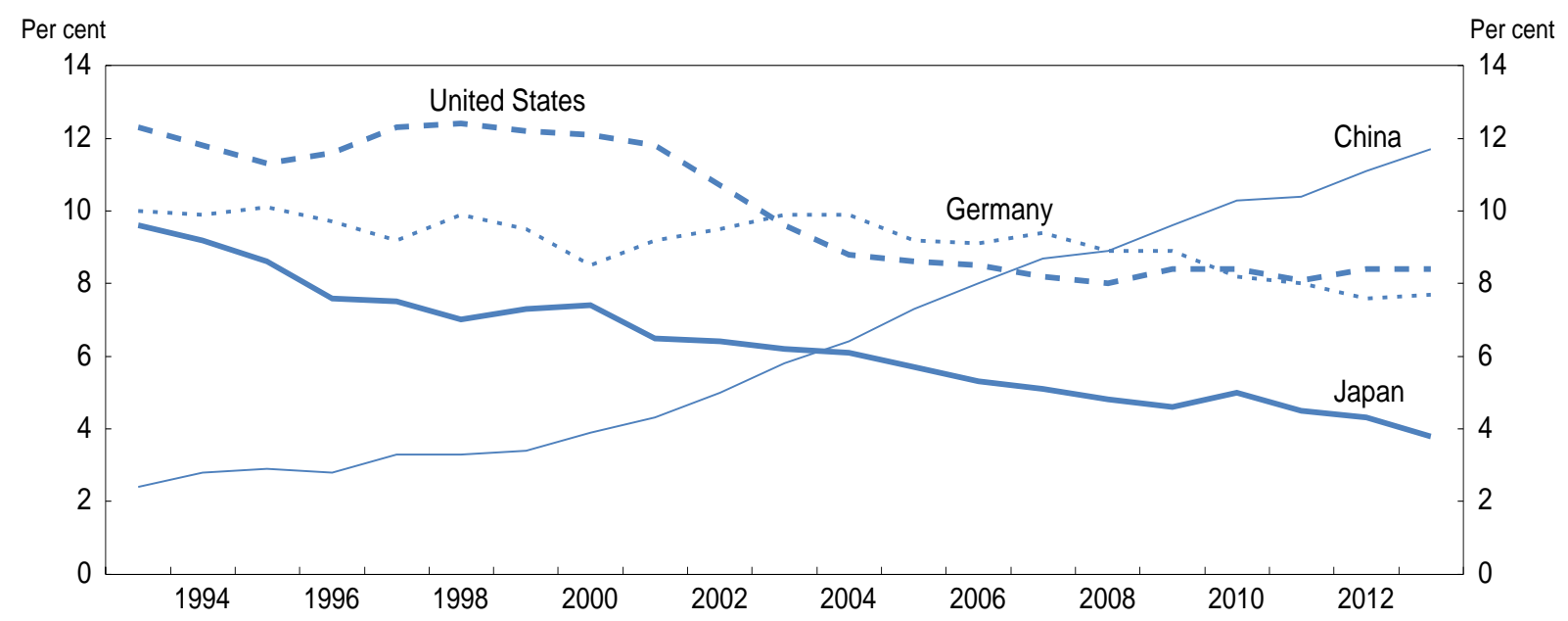

Source: WTO Database.

The loss in world export market share has prompted fears of deindustrialisation ("hollowing out"), a recurring theme since the 1980s (Nakamura and Shibuya, 1995). Indeed, the share of the manufacturing sector in nominal GDP has fallen from one-third in 1970 to around one-fifth. As for employment, the number of workers in manufacturing fell by nearly one-third, from 13.9 million to 9.9 million in 2011. 


\section{Box 1. Reversing the terms-of-trade decline to boost purchasing power in Japan}

Japan has suffered from terms-of-trade losses each year since 2000 (except 2009), more than offsetting net overseas income and pushing gross national income (GNI) below GDP (Figure 5). High terms of trade mean that a country can sell its products at a high price and buy cheaply from overseas. Terms-of-trade losses reduce purchasing power, putting downward pressure on wages and profits. Indeed, a government study found that termsof-trade losses reduce domestic demand with a lag of around two years (Cabinet Office, 2009). International studies also show that the terms of trade have a critical impact on GDP growth (Wong, 2010). If Japan's terms of trade had remained at their 2000 level, per capita GNI in 2014 would have been 6\% higher, based on a mechanical calculation.

Figure 5. Terms-of-trade losses are putting downward pressure on gross national income ${ }^{1}$

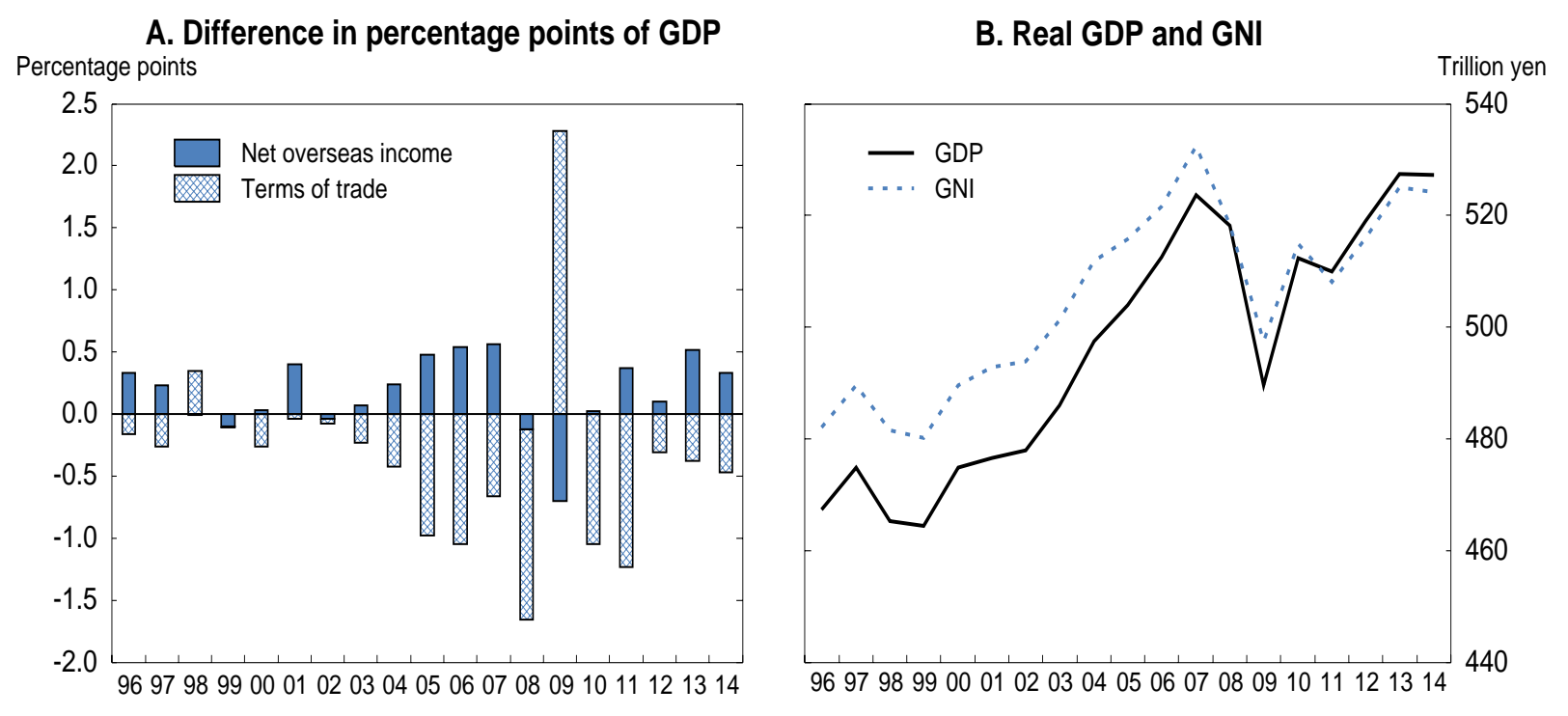

1. Real GNI $=$ Real GDP + Net overseas income + terms-of-trade effect. Net overseas income is defined as primary incomes receivable from non-resident units minus primary incomes payable to non-resident units. The terms-of-trade are the ratio of the export and import price deflators.

Source: Cabinet Office.

Japan's terms of trade have fallen by about $40 \%$ over the past 20 years, in contrast to the OECD area, where they have been relatively stable (Figure 6). Import prices have risen, although less than for the OECD area (Panel B). Import price increases reflect the rising cost of oil and commodities, at least through 2012 . The $25 \%$ decline in Japan's export prices over 1994-2012, though, is exceptional (Panel C). In contrast, export prices increased by $10 \%$ and $28 \%$ for Germany and the United States, respectively. In 2014, Japan's terms of trade were by far the lowest among OECD countries (Panel D).

Japan experienced an adverse terms-of-trade shock due to the emergence of low-cost producers of manufactures in Asia (Coleman, 2005). The downward trend in export prices is fundamentally a competitiveness problem; Japanese firms have responded to severe price competition with other Asian producers by reducing export prices in an unsuccessful attempt to maintain market share. Moreover, Japan has concentrated in electronic machinery, a category that has experienced rapid technological change as well as intense competition. In contrast, other countries exporting manufactures, such as Germany, have not experienced significant terms-of-trade losses.

Yen depreciation over 2012-14 (24\% relative to the dollar on a calendar year basis) has had an asymmetrical effect on export and import prices in yen terms. While import prices rose by $15 \%$, despite falling world prices for oil and commodities, export prices increased by only $11 \%$, resulting in a further deterioration in the terms of trade. In general, though, exchange rate fluctuations have limited impact on the terms of trade (Nezu, 2011).

In its 2013 Japan Revitalisation Strategy, the government set a target of boosting per capita GNI by more than 1.5 million yen to 5.3 million yen (around $\$ 45000$ ) by 2023. Reversing the decline in the terms of trade would help achieve the target. Enhancing Japan's overall competitiveness would help firms improve non-price competitiveness and avoid the commodification of their products. 


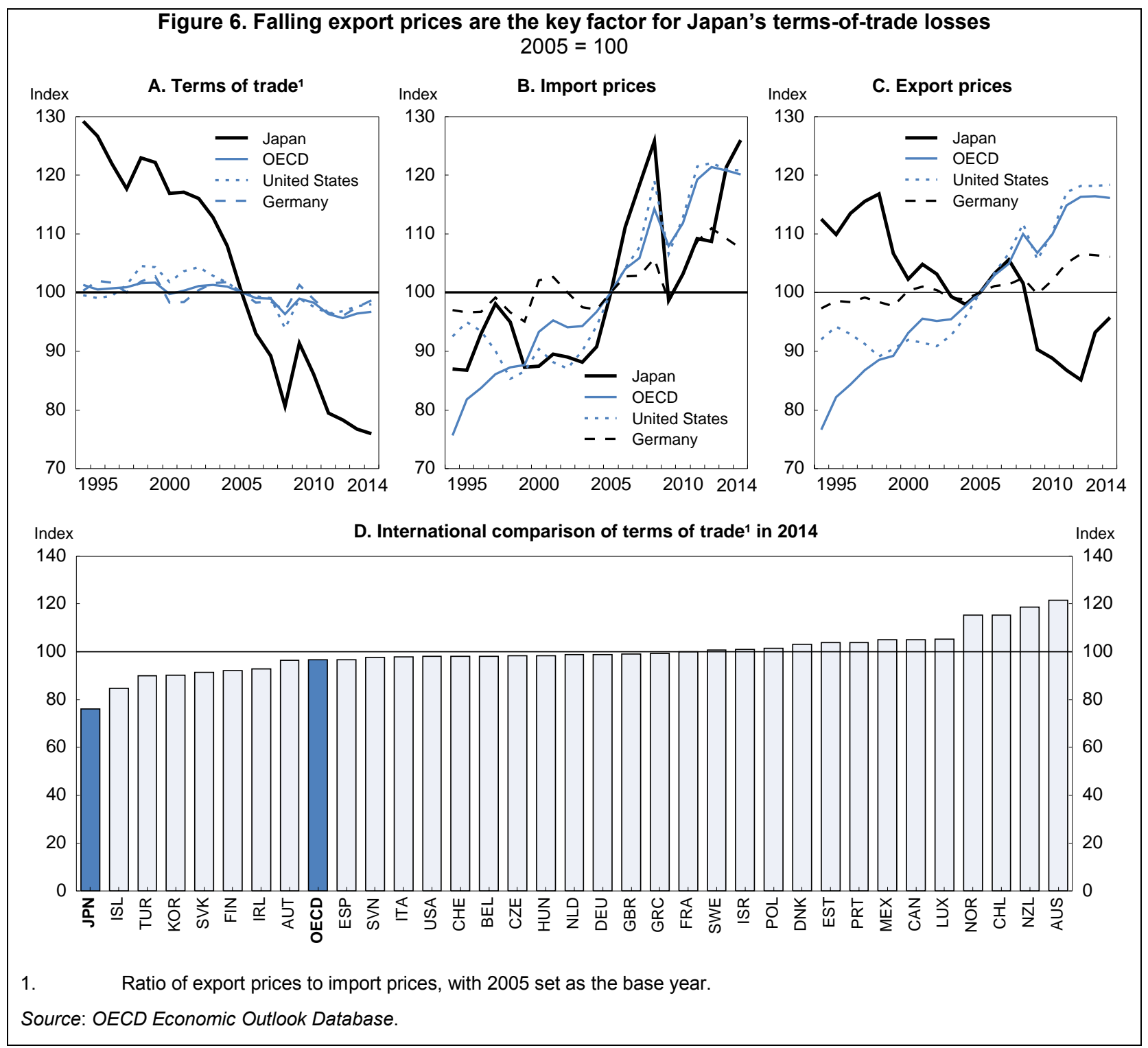

However, the fall of the manufacturing sector in nominal GDP since 1970 masks a marked rise in its share of GDP in real terms (from 17.6\% to 23.2\%) (Figure 7, Panel A, Line A). The large difference between manufacturing's share of GDP in nominal and real terms is explained by rapid productivity gains that have reduced the relative prices of manufactures (Line C). Indeed, TFP in manufacturing has increased 77\% relative to the total economy since 1970 (Figure 7, Panel B, Line D). With TFP rising so rapidly, the share of factor inputs, including labour, allocated to manufacturing has fallen significantly (Line E).

In addition to higher productivity growth, the falling share of manufacturing in nominal GDP and the labour force also reflects factors such as the shift of demand from manufactures to services and offshoring to lower-cost environments. Japan's share of outward FDI matched the OECD average of $23 \%$ of GDP in 2013. Deindustrialisation is thus a common trend in advanced economies; for the OECD area, the share of manufacturing (in nominal terms) has fallen by 3.5 percentage points since 1994 to $15.6 \%$ (Figure 8). The decline in Japan's manufacturing sector - from $22 \%$ to $18.5 \%$ - is similar and leaves it above the OECD average. In terms of labour inputs, manufacturing's share of total employment fell from $21 \%$ in 1994 to $15 \%$ in 2013, slightly above the $14 \%$ OECD average (Panel B). 
Figure 7. Long-term trends in Japan's manufacturing sector

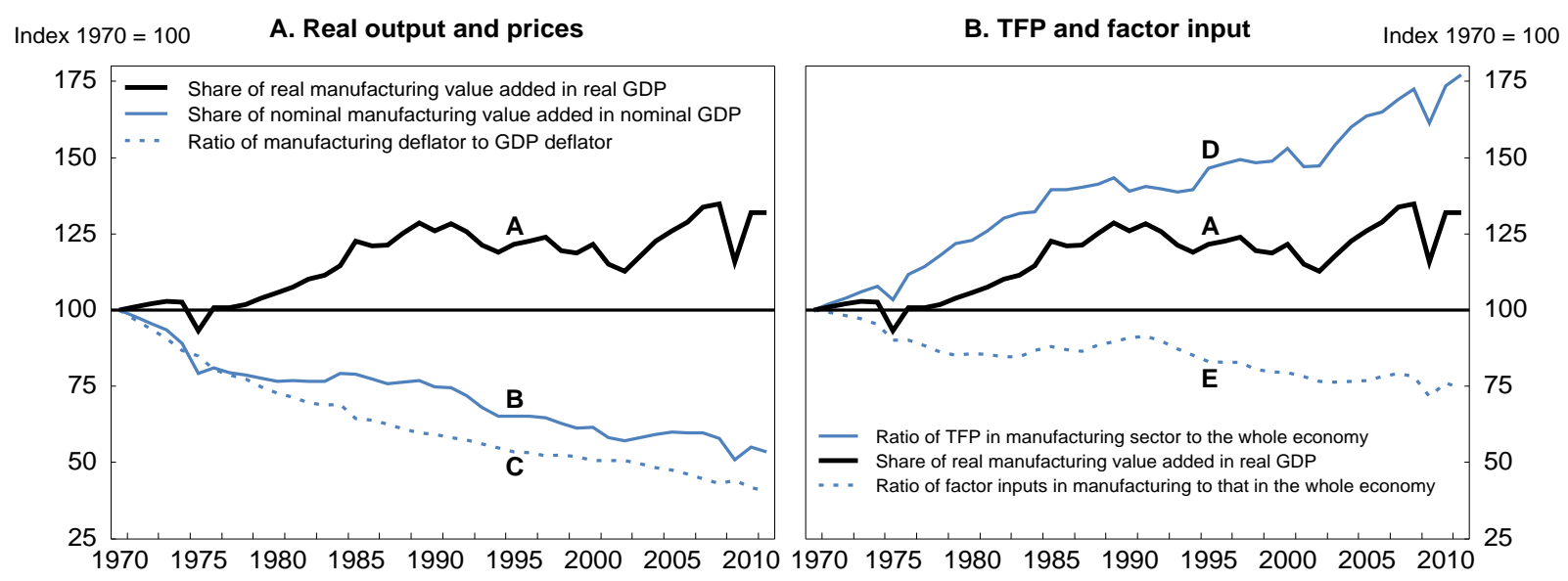

Source: Japan Industrial Productivity Database 2014.

Deindustrialisation is thought to have a number of adverse effects. First, to the extent that TFP growth is higher in manufacturing, deindustrialisation may reduce economy-wide TFP growth. However, in Japan, relatively labour-intensive industries with low TFP growth have shrunk, limiting any negative impact. Second, given that $\mathrm{R} \& \mathrm{D}$ is concentrated in manufacturing, deindustrialisation may reduce the $\mathrm{R} \& \mathrm{D}$ base. Third, the closure of factories reduces technology spillovers from large to small firms (negative "exit" effects) (Fukao, 2012). Nevertheless, policies to stop deindustrialisation, such as trade barriers or restrictions on the globalisation of Japanese firms, would only hurt economic growth. Indeed, outward investment is a way to capture overseas demand, which boosts Japan's national income through interest and dividend payments.

Rather than deindustrialisation, Japan's key problem is the lack of TFP growth in non-manufacturing, which has been declining since its peak in 1991 (Figure 9). This reflects the low level of R\&D in the service sector, which accounted for only $9 \%$ of business R\&D in 2011, well below the OECD average of $38 \%$. The challenge is to boost TFP growth, particularly in services, which account for a growing share of output. This requires addressing three key issues: cash hoarding in the corporate sector, ineffective investment in knowledge-based capital (KBC) and low corporate profitability.

Figure 8. International comparison of trends in manufacturing ${ }^{1}$

\section{$\begin{array}{ll}\text { A. Manufacturing value added } & \text { B. Manufacturing employment }\end{array}$}
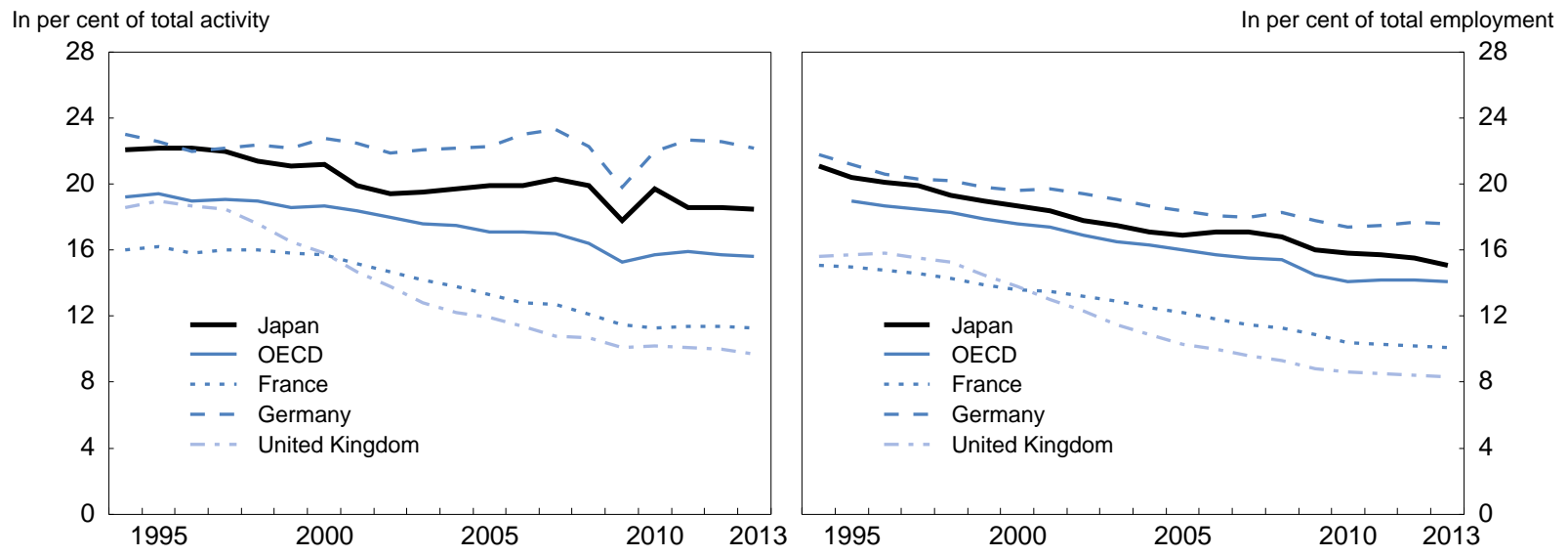

1. Based on ISIC4 in nominal terms. It is important to note that the fall in the share of manufacturing may be overstated by the outsourcing of service activities that were previously performed in-house.

Source: OECD National Accounts Database. 
Figure 9. The productivity gap between manufacturing and non-manufacturing has widened sharply

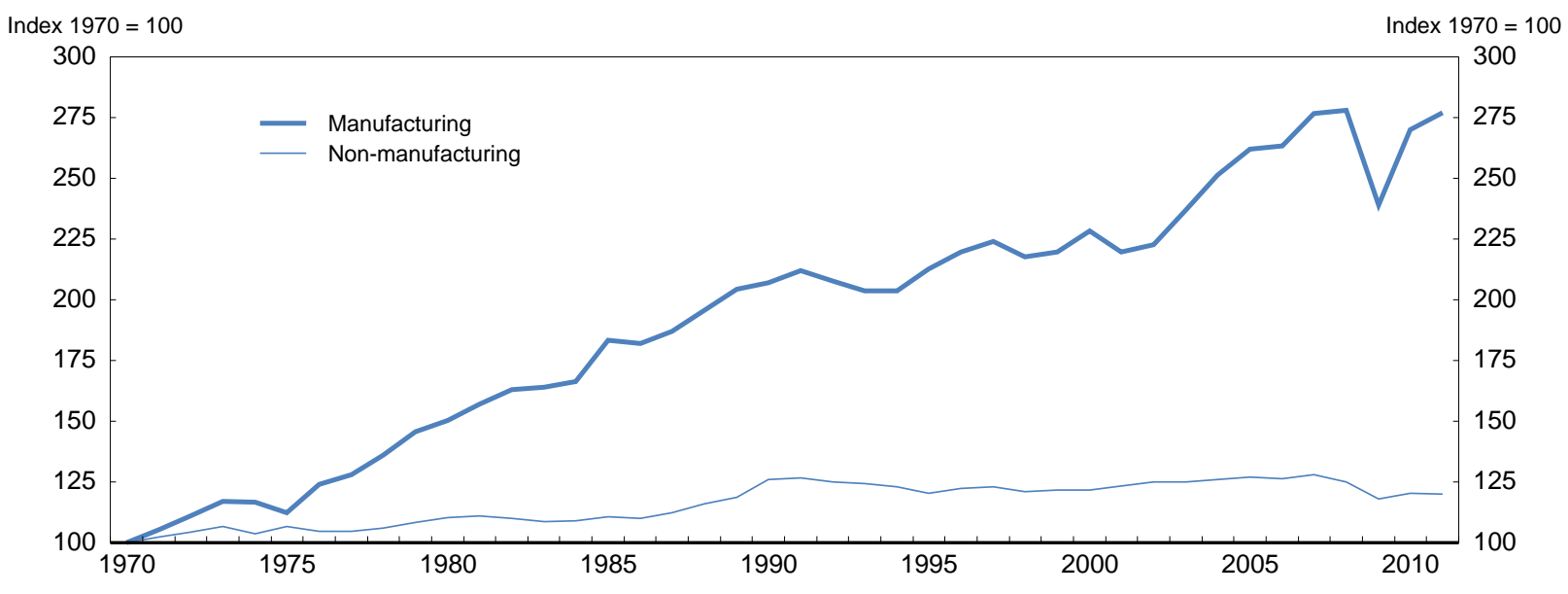

Source: Japan Industrial Productivity Database 2014.

\section{Addressing three key issues in the corporate sector}

The corporate sector has had a saving surplus since 1998 (Figure 10), helping to reduce gross corporate debt from $115 \%$ of GDP in 1998 to $76 \%$ in 2012 and restore liquidity buffers. Indeed, cash holdings of listed non-financial firms reached $28.5 \%$ of market capitalisation in 2011, compared to only $14 \%$ in 2000, and is far above the US and European levels (Panel B). Cash holdings amounted to $62 \%$ of GDP in FY 2012 (Ministry of Finance, 2014). Moreover, Japan's corporate sector's holdings of cash and deposits combined reached $56 \%$ of market capitalisation, compared to an average of $25 \%$ in other G7 countries. Consequently, the share of listed firms that hold cash and deposits exceeding their interestbearing debt (i.e., firms without net external borrowings) rose from $24 \%$ in 1998 to $43 \%$ (Shirakawa, 2013).

Figure 10. Japan's corporate sector has a saving surplus and large cash holdings
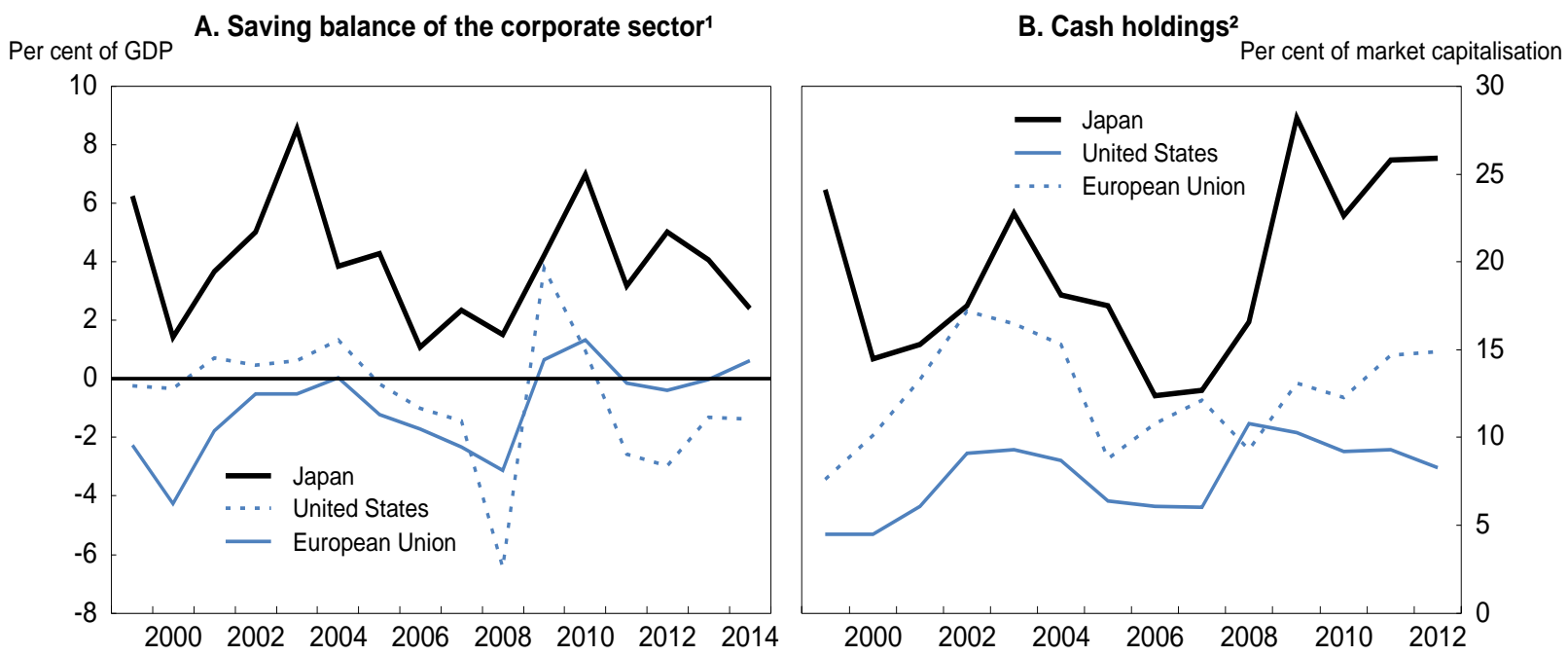

1. For the US and Japan, data are available through 2014:Q3 and for the EU, 2014:Q2.

2. Cash and marketable securities of listed companies as a percentage of market capitalisation in each country or region. For Japan - Topix 500 index; US - S\&P 500, euro area - Bloomberg Europe 500.

Source: Bank of Japan (2014), Flow of Funds: Comparison of US and Europe; Bloomberg; OECD calculations. 
High cash holdings in Japan are not driven by specific industries, but are instead broad-based, as the corporate sector seeks a buffer against shocks. Since the bubble collapse in the early 1990s, reducing debt has been a priority for firms. Cash holdings increased sharply during Japan's banking crisis in the early 2000 s and in the wake of the 2008 global crisis, as funding conditions became severe and cash flow volatility increased (Shinada, 2012). A number of other factors help explain high cash holdings. First, persistent deflation has encouraged firms to hold cash rather than pursue more productive uses of resources (Kuroda, 2013). Second, cross-country studies show that good corporate governance tends to reduce cash holdings by addressing the agency problem stemming from the different objectives of management and shareholders, who tend to focus more on short-term profits. A study of 3400 Japanese firms suggests that improving corporate governance would significantly reduce cash holdings (Aoyagi and Ganelli, 2014). Third, regulations that make takeovers rare in Japan reduce the pressure on managers to act in the interest of shareholders by reducing cash holdings (Kinoshita, 2013). Fourth, the pressure on managers is further reduced by cross-shareholdings, which focus on mutual benefits rather than maximising profits.

Corporate cash holdings in Japan have risen beyond what a standard model of corporate cash demand would imply as appropriate (Aoyagi and Ganelli, 2014). High cash holdings can prevent firms from maximising their return on assets, thereby holding back aggregate demand and limiting output growth (Shinada, 2012). Indeed, high and rising cash holdings have coincided with a negative contribution of private investment to growth during recent years and falling real wages despite positive labour productivity growth. While holding high levels of cash on their balance sheet may be rational for an individual firm, the end result is a suboptimal equilibrium, a "paradox of thrift", calling for reform (Aoyagi and Ganelli, 2014).

Cash holdings can be reduced in one of three ways: increased dividend payments to stockholders, more investment, and faster wage growth, which the government has strongly encouraged. Reducing cash reserves requires changing the business environment, for example by improving corporate governance (see below) to modify firms' incentives. Investment, in particular, would be boosted by regulatory reforms. Indeed, Abenomics' third arrow is officially "the growth strategy for promoting investment".

Channelling part of the excess liquidity into investment in knowledge-based capital (KBC) would have a particularly positive effect on productivity and growth. Indeed, most of the income gaps between developed economies cannot be explained by the stock of labour and tangible capital, but instead depend on investment in $\mathrm{KBC}$, which includes: i) innovative property (R\&D, copyright and license costs); ii) computerised information (software and databases); and iii) economic competencies (firm-specific human capital, organisational structure, brand equity) (OECD, 2013e). Japan's level of investment in KBC is in the top third of OECD countries for which data are available, at $8 \%$ of GDP (Figure 11). However, the contribution of $\mathrm{KBC}$ to labour productivity growth is one of the lowest among OECD countries (Panel B).

While investment in innovative property in Japan is large, driven by high R\&D spending in manufacturing, investment in the other two categories of software and economic competencies is lower. The lack of labour flexibility (see below) limits investment in software, which is profitable to the extent that it is accompanied by organisational changes that allow firms to reduce inputs of unskilled labour (Fukao et al., 2014). Limited labour flexibility has also contributed to the rise in the share of non-regular workers from $20 \%$ in 1990 to $37 \%$ in 2014 , of which about one-third are temporary workers. Labour market dualism also helps explains the fall in investment in economic competencies to $2 \%$ of GDP (Figure 11), as firms have less incentive to train temporary workers. Indeed, 59\% of firms provide on-thejob training to regular workers but only $29 \%$ provide it to non-regular workers (Ministry of Health, Labour and Welfare, 2014). Other factors cited for low investment in intangibles include: $i$ ) weak incentives for management to boost efficiency; ii) the smaller share of young firms, which tend to invest more in intangibles; and iii) the prevalence of small shops in the retail sector (Fukao et al., 2014). 
Figure 11. Investment in knowledge-based capital
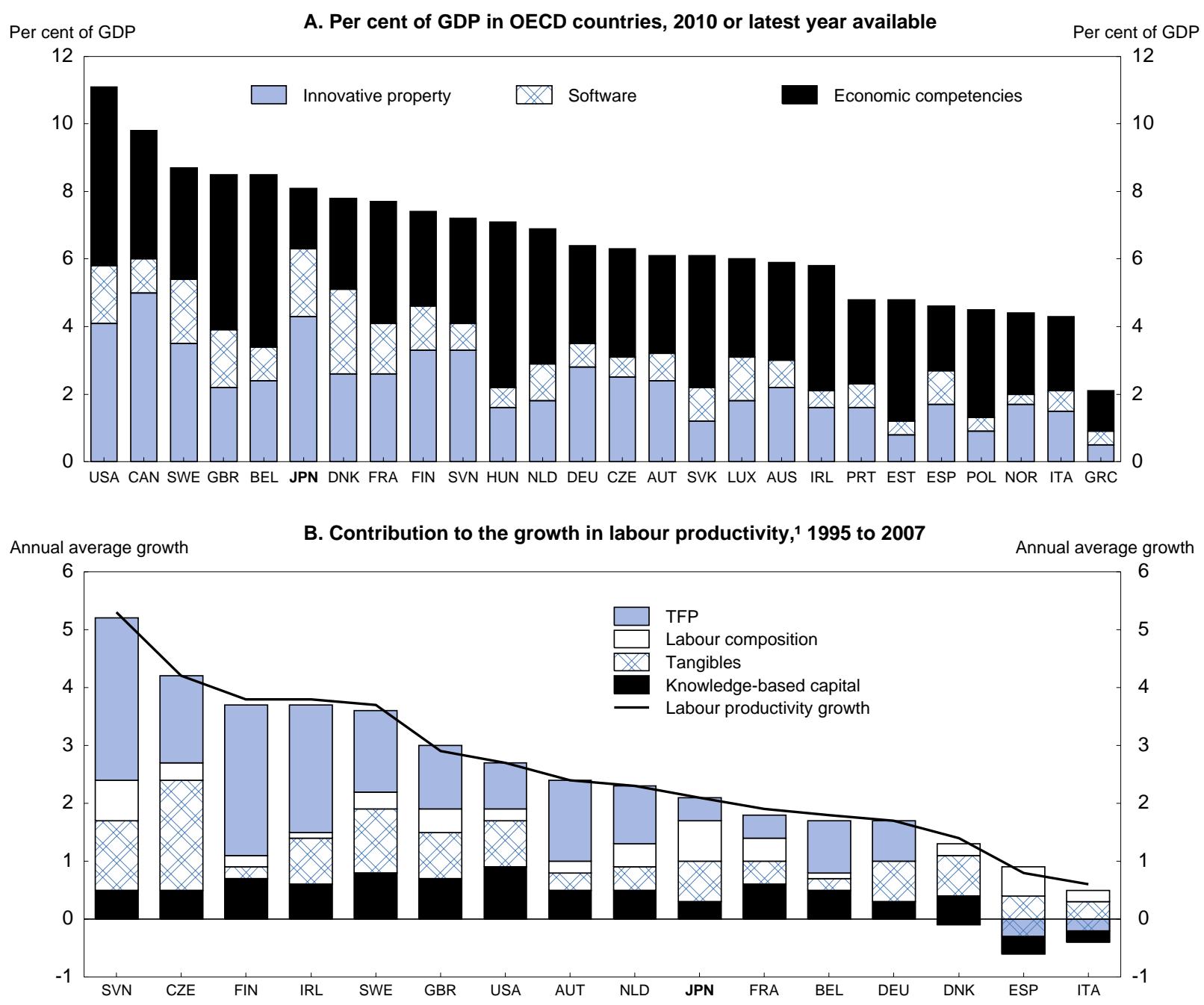

1. Annual average growth rate from 1995 to 2007 of output per hour worked.

Source: Corrado et al. (2012); Andrews and Criscuolo (2013).

Using the high cash holdings to boost investment in intangible assets could also improve profitability. Operating profits in Japan have fluctuated around $6 \%$ of sales, about half of the level of the United States and Europe (Kinoshita, 2013). In Japan, the rate of return on assets has been on a long-term downward trend in both manufacturing and non-manufacturing, as the 2002-08 rebound appears to have been only temporary (Figure 12). The return on equity is far below that in the United States and Europe in both manufacturing and non-manufacturing (Panel B). Addressing the issues of high cash holdings, ineffective investment in $\mathrm{KBC}$ and low corporate profitability requires improving framework conditions to strengthen competition, upgrade the innovation system, promote the creation of start-ups, including venture capitalbacked firms, and revitalise the SME sector. 
Figure 12. Return on assets have fallen, while return on equity is relatively low
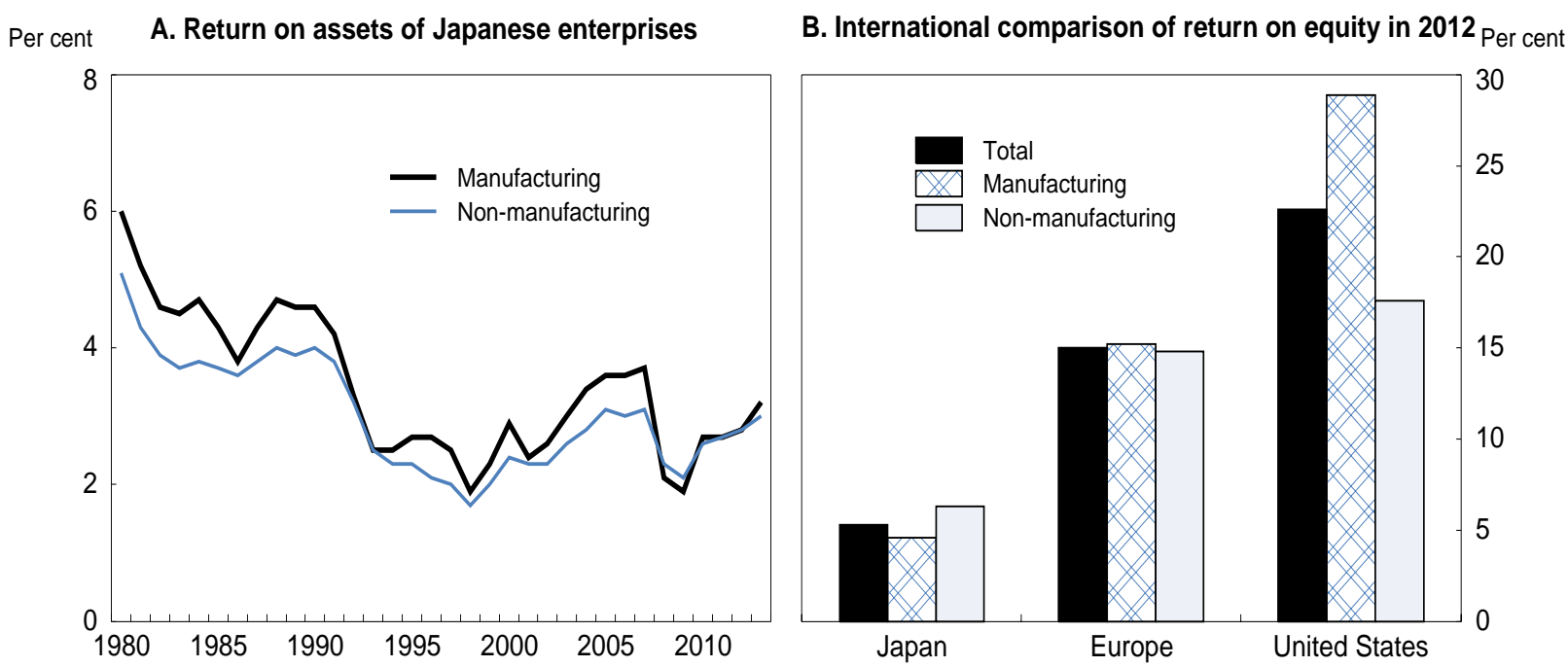

Source: Ministry of Finance (2014), Annual Survey of Business Conditions; Ministry of Economy, Trade and Industry (2014).

\section{Framework conditions to promote innovation and boost productivity}

Appropriate framework conditions are needed to encourage firms to participate in innovation and allow its benefits to spread throughout the economy. As noted above, cross-country differences in productivity and growth are largely explained by TFP, which in turn depends on a reallocation of resources in favour of innovative firms. Stronger competitive pressure would push firms to innovate and invest their cash. If the market works, firms that fail to adopt the most productive technologies have to downsize or exit, thereby releasing resources to more efficient firms, maximising productivity and output growth. The ability to rapidly reallocate labour and capital is particularly important in innovative sectors so that firms can capture the value of their ideas before imitation by competitors (Andrews and de Serres, 2012). Such flexibility raises the amount of investment in KBC by increasing its return (Andrews and Criscuolo, 2013). On the other hand, frictions in resource reallocation lower the expected net benefits of innovation.

The speed at which resources are reallocated to innovative firms depends on a number of factors discussed below, as well as competition policy. Enforcement by Japan's Fair Trade Commission has been classified as "very good" by the Global Competition Review (Global Competition Review, 2013). However, there is room to improve competition policy by reducing exemptions to the Anti-Monopoly Act and increasing administrative fines (2008 OECD Economic Survey of Japan).

\section{Improving corporate governance}

Corporate governance is a key determinant of an economy's competitiveness and growth as it affects access to equity, the allocation of equity and the monitoring of firms' performance (Isaakson and Çelik, 2013). Japan is one of the few advanced countries without a corporate governance code. In 2004, the Tokyo Stock Exchange (TSE) introduced "Principles of Corporate Governance for Listed Companies". However, it did not provide detailed rules for governance, nor was there any obligation to comply. As noted above, weaknesses in corporate governance are linked to a number of problems, including the low rate of return on assets and the large cash holdings of Japanese firms (Aoyagi and Ganelli, 2014). The 2014 "Japan Revival Vision" by the ruling Liberal Democratic Party states that Japan's corporate governance "lags other countries". 
The Vision also calls for lower cross-shareholding, which has "reduced the sense of crisis among management of Japanese companies for many years" and slowed industrial restructuring. While crossshareholdings between companies with business ties provide mutual benefits and help fight takeover bids, they block the interests of investors seeking financial gains (Ueda, 2014). In 1985, city and regional banks and non-financial firms held half of shares by value (Figure 13). While the banks' shareholdings have fallen sharply, non-financial firms account for one-fifth of total shareholdings.

Figure 13. Shareholder composition of Japanese companies

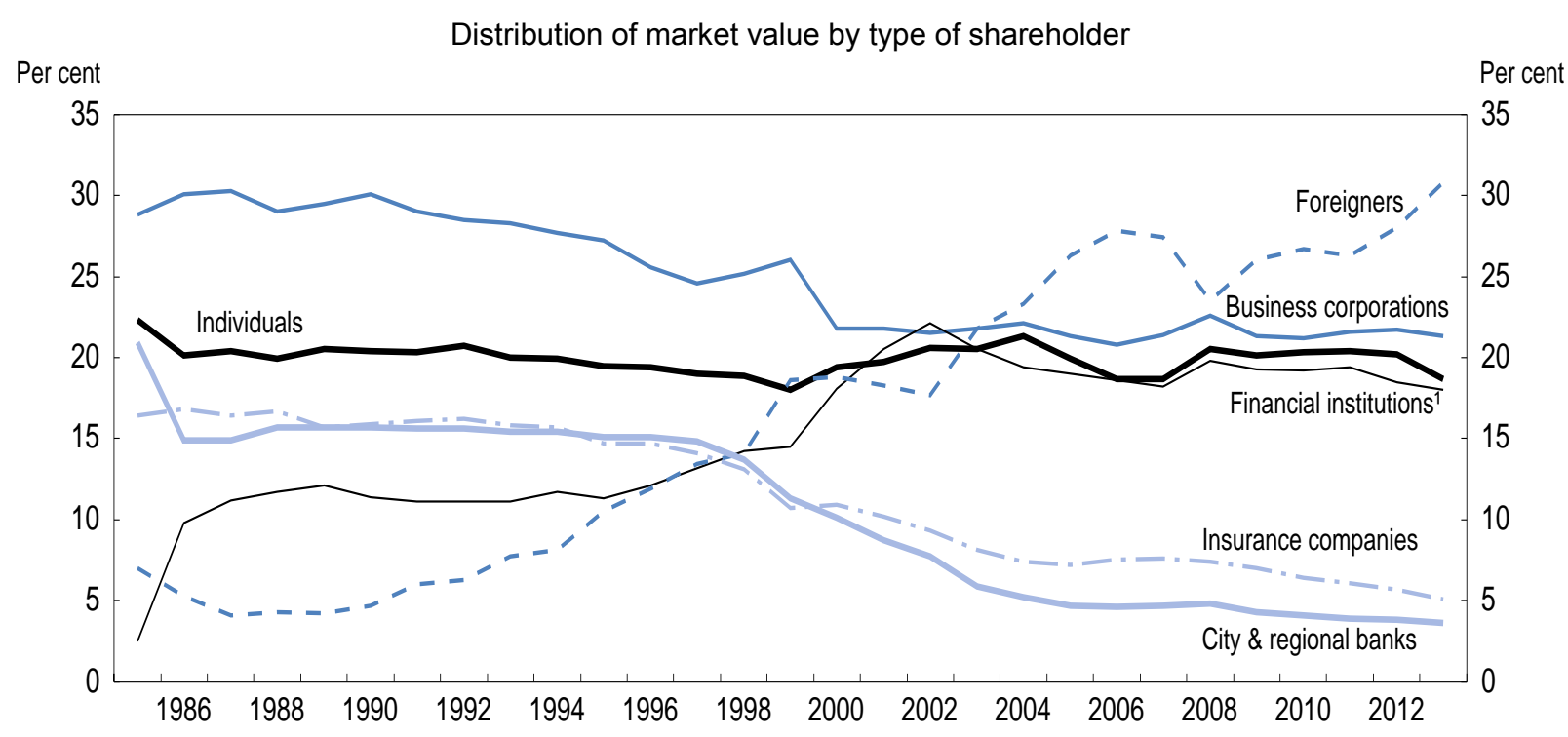

1. Excluding insurance companies and city and regional banks.

Source: Tokyo Stock Exchange, 2013 Share Ownership Survey.

Recent trends in shareholding reveal a number of other changes (Figure 13):

- The proportion of shares held by individuals has been stagnant, while insurance companies' shareholdings have fallen.

- Foreign investors have become a major player in the Japanese stock market, as their shareholdings have risen from 7\% of the total in FY 1985 to 31\% in FY 2013.

- Despite the falling shareholding by insurance companies, domestic institutional investors are playing an important role, as in other advanced countries.

The expanding role of foreign investors and institutional investors, both domestic and foreign, are helping to strengthen corporate governance. Meanwhile, the shrinking shareholdings of a number of domestic investor categories puts downward pressure on share prices and encourages firms to improve corporate governance to attract investors from other countries. In short, the changing structure of corporate ownership is a catalyst for improving corporate governance.

A number of steps have been taken recently to improve corporate governance. The "JPX-Nikkei Index 400" was launched in January 2014 to "activate the stock market". The index is composed of 400 firms chosen in part on the basis of quantitative criteria, including return on equity (ROE). Indeed, the JPXNikkei 400 companies had an average ROE of 11\% over FY 2011-13 compared to 4\% for companies in the first section of the TSE that were not chosen. In addition, qualitative factors, such as the use of two or more independent, external directors on corporate boards, were used to select the 400 companies. The JPXNikkei 400 is thus harnessing market forces to improve corporate governance. 
This was followed in February 2014 by the introduction of a "Stewardship Code", which obliges participating institutional investors to fulfil their responsibilities through "constructive dialogue" with the firms in which they invest. The Code is based on a "comply or explain" approach. Institutional investors that adopt the Code are expected to appropriately monitor their investee companies and report periodically on how they fulfil their stewardship responsibilities, including voting. In addition to boosting the return to their clients, institutional investors that fulfil these functions perform a socially beneficial role by providing new information that will improve resource allocation and the performance of investee firms (Çelik and Isaksson, 2013). By November 2014, 175 companies had adopted the Code (FSA, 2014). The number is likely to increase, as institutional investors who fail to adhere to the Code will lose clients.

However, the ability of investors to be good stewards is limited by Japan's lack of a corporate governance code. The 2014 revision of the Revitalisation Strategy called on the TSE and the Financial Services Agency to prepare such a code based on the OECD's Principles of Corporate Governance. A draft code was submitted for public comment in December 2014 and is to take effect for nearly 3400 companies in mid-2015. It will apply a "principles-based approach" that is not legally binding but aims to contribute to the "success of companies, investors and the economy". It includes five major principles:

- Securing the rights and equal treatment of shareholders: Companies should take appropriate measures to fully secure shareholder rights, giving adequate consideration to minority and foreign shareholders. Companies with cross-shareholdings should explain the rationale for such holdings.

- Appropriate co-operation with stakeholders other than shareholders: Companies should recognise that their growth depends on a range of stakeholders, including employees, customers and local communities. They should also promote diversity, including the active participation of women.

- Ensuring appropriate information disclosure and transparency: The board of directors should recognise that information is the basis for constructive dialogue with shareholders and therefore ensure that such information, particularly non-financial information, is accurate, clear and useful.

- Responsibilities of the board: The board should set the broad direction of corporate strategy, establish an environment where appropriate risk-taking by the senior management is supported and carry out effective oversight from an independent and objective standpoint. Companies should make effective use of outside (referred to as independent) directors. Boards should establish and disclose standards aimed at securing the effective independence of their outside directors.

- Dialogue with shareholders: Companies should engage in constructive dialogue with shareholders.

Much of the debate on corporate governance focuses on outside directors, who are expected to be more effective in monitoring management and ensuring that they run the firm for shareholders' benefit. However, boards of directors in Japan are dominated by insiders, notably long-term employees, who play a major role in decision-making, contributing to a lack of transparency in corporate governance (Miyajima, 2013). The revised Companies Act and the TSE require companies to have at least one outside director on a comply or explain basis (Table 1). The average number of outside directors in Japan has risen from 0.9 per company in 2008 to 1.3 in 2014 for the nearly 1800 companies listed on the TSE's first section. However, $39 \%$ of these companies did not have any outside directors. In contrast, outside directors are legally mandatory in the United States (a majority of the board) and Korea (at least one quarter). Corporate governance codes require outside directors in the United Kingdom (at least half) and France (half). Indeed, a 2013 survey by Institutional Shareholder Services found that only $0.2 \%$ of Japanese listed companies had a majority of outside directors, compared to $50 \%$ in the United Kingdom and $90 \%$ in the United States. 
ECO/WKP(2015)79

Table 1. Rules on outside directors of listed companies

\begin{tabular}{|c|c|c|c|c|c|c|c|}
\hline & & Japan & $\begin{array}{c}\text { United } \\
\text { Kingdom }\end{array}$ & Germany & France & $\begin{array}{l}\text { United } \\
\text { States }\end{array}$ & Korea \\
\hline Manc & y rule & -- & -- & -- & -- & $\begin{array}{l}\text { Majority } \\
\text { of the board } \\
\text { (listing }\end{array}$ & $\frac{\text { Not less }}{\text { than } 1 / 4}$ \\
\hline & $\begin{array}{l}\text { Comply } \\
\text { rule } \\
\text { on outside } \\
\text { directors }\end{array}$ & $\frac{\text { At least one }}{\begin{array}{c}\text { (amended } \\
\text { listing rules) }\end{array}}$ & $\begin{array}{l}\text { At least half } \\
\text { of the board, } \\
\text { excluding the } \\
\text { chairman }\end{array}$ & $\begin{array}{c}\frac{\text { Adequate }}{\text { number }} \\
\text { (Corporate } \\
\text { Governance } \\
\text { Code) }\end{array}$ & $\begin{array}{l}\text { Half } \\
\text { of the board } \\
\text { (Corporate } \\
\text { Governance } \\
\text { Code) }\end{array}$ & & \\
\hline $\begin{array}{l}\text { Comply } \\
\text { or } \\
\text { explain }\end{array}$ & $\begin{array}{c}\text { Legal basis } \\
\begin{array}{c}\text { Regulatory } \\
\text { body }\end{array} \\
\end{array}$ & $\begin{array}{c}\text { Amended } \\
\text { listing rules } \\
\text { Stock } \\
\text { Exchange }\end{array}$ & $\begin{array}{c}\text { Corporate } \\
\text { Governance } \\
\text { Code } \\
\text { Independent } \\
\text { Legal Entity }\end{array}$ & $\begin{array}{l}\text { Corporate } \\
\text { Governance } \\
\text { Code } \\
\text { Government } \\
\text { commission }\end{array}$ & $\begin{array}{c}\text { Corporate } \\
\text { Governance } \\
\text { Code } \\
\text { Enterprise } \\
\text { Association }\end{array}$ & & \\
\hline & $\begin{array}{l}\text { Explain } \\
\text { rule }\end{array}$ & $\begin{array}{c}\text { Verbal } \\
\text { explanation at } \\
\text { the } \\
\text { shareholders' } \\
\text { meeting }\end{array}$ & Disclosure & Disclosure & Disclosure & -- & -- \\
\hline & Legal basis & $\begin{array}{l}\text { Amendment } \\
\text { bill of the } \\
\text { companies act }\end{array}$ & Listing rules & $\begin{array}{c}\text { Stock } \\
\text { corporation act }\end{array}$ & $\begin{array}{l}\text { Commercial } \\
\text { code }\end{array}$ & & \\
\hline (Reference) & $\begin{array}{c}\text { Corporate } \\
\text { governance } \\
\text { code }\end{array}$ & & $\boldsymbol{V}$ & $\boldsymbol{V}$ & $\boldsymbol{V}$ & & \\
\hline & $\begin{array}{l}\text { Stewardship } \\
\text { code }\end{array}$ & $\underset{(\text { Feb. 2014) }}{\boldsymbol{V}}$ & $V$ & -- & -- & -- & -- \\
\hline
\end{tabular}

1. Regulators establish a rule, which companies may either comply with or explain publicly why they do not. The purpose of this approach is to let the shareholders decide whether the companies' decision is appropriate.

Source: OECD (2014c).

The low share of outside directors in Japan reflects the reluctance of some managers to introduce a system that inhibits their freedom of action (Saito, 2009). Some argue that firms should be free to choose the optimal composition of their board of directors based on the nature of their business. Moreover, the presence of outside directors has not prevented scandals at some companies. This suggests that management can defeat the purpose of outside directors by appointing ones that are loyal to it.

The draft code would require "multiple" outside directors. The appointment of outside director(s) in Japan has been found to have a significantly positive impact on a company's share price and profit margin (Saito, 2009), and to boost firms' ROE (Investor Impact, 2014). Requiring at least two outside directors would strengthen governance by corporate boards, which have an average of nine members. However, it has been argued that at least three outside directors are necessary to give them a strong voice.

The benefits from appointing outside directors in Japan are largest in business lines where information is easily available to outsiders. However, such firms have the lowest numbers of outside directors (Miyajima, 2012), showing that simply leaving the decision to the market and managers will not improve the situation. The use of outside directors is desirable and should become the norm, while making companies that opt out explain their non-compliance in a way that will "gain full understanding from shareholders" (Council of Experts, 2014). However, there remains a risk that powerful business organisations may prepare a standard explanation form for firms that choose to not appoint outside directors, thereby undermining the effectiveness of the comply or explain approach by protecting them from an adverse response from investors (Fujita, 2013). 
The benefits of outside directors depend on the independence of those directors and their expertise. A majority of outside directors in Japan at present are actually ex-employees or partners of the firm and most are appointed for the benefit of the inside directors rather than shareholders (Kinoshita, 2013). A member of the Council of Experts Concerning the Corporate Governance Code has expressed concern that the current criteria for independent directors established by securities exchanges are "abstract and they allow considerable room for interpretation" (Council of Experts, 2014). Moreover, the compensation of outside directors should be more strongly linked to shareholders' dividends. Finally, directors should receive training from independent sources on their fiduciary responsibilities and should not have to rely exclusively on information provided to them by management. Unlike some jurisdictions, Japan has no rules requiring director training or disclosure thereof (OECD, 2014b). In the draft code, companies are responsible for providing training to their directors.

\section{Labour market flexibility: relaxing employment protection}

Innovation requires continuous reallocation of labour and other resources within and across firms and sectors. There is considerable evidence that employment protection has a major impact on labour flows (Martin and Scarpetta, 2012). Low levels of protection allow resources to flow to their most productive uses, benefiting innovative firms that require large employment adjustments. But high employment protection hinders resource reallocation, weakening productivity growth and innovation:

- It reduces $R \& D$ expenditure, particularly in innovative sectors (Andrews and Criscuolo, 2013). Firms in industries characterised by rapid technological change place a high value on flexibility. By raising exit costs, stringent employment protection makes experimentation less attractive.

- It reduces the ability of innovative firms to attract the resources needed to implement and commercialise new ideas. The increase in the work force in a firm that experienced a $10 \%$ rise in patents ranged from $0.3 \%$ to $2.2 \%$ depending on the strictness of employment protection, while the increase in capital ranged from $0.9 \%$ to $3.3 \%$ (Figure 14 ).

- Employment protection impedes venture capital financing in innovative sectors, which rely on rapid resource reallocation across the investment portfolio from failing to successful ventures.

- Multinational enterprises tend to concentrate more technologically-advanced innovation in countries with low employment protection, thus making resource shifts easier.

Figure 14. Impact of the stringency of regulation on resource allocation

For a firm with a $10 \%$ increase in its patent stock over 2002-10
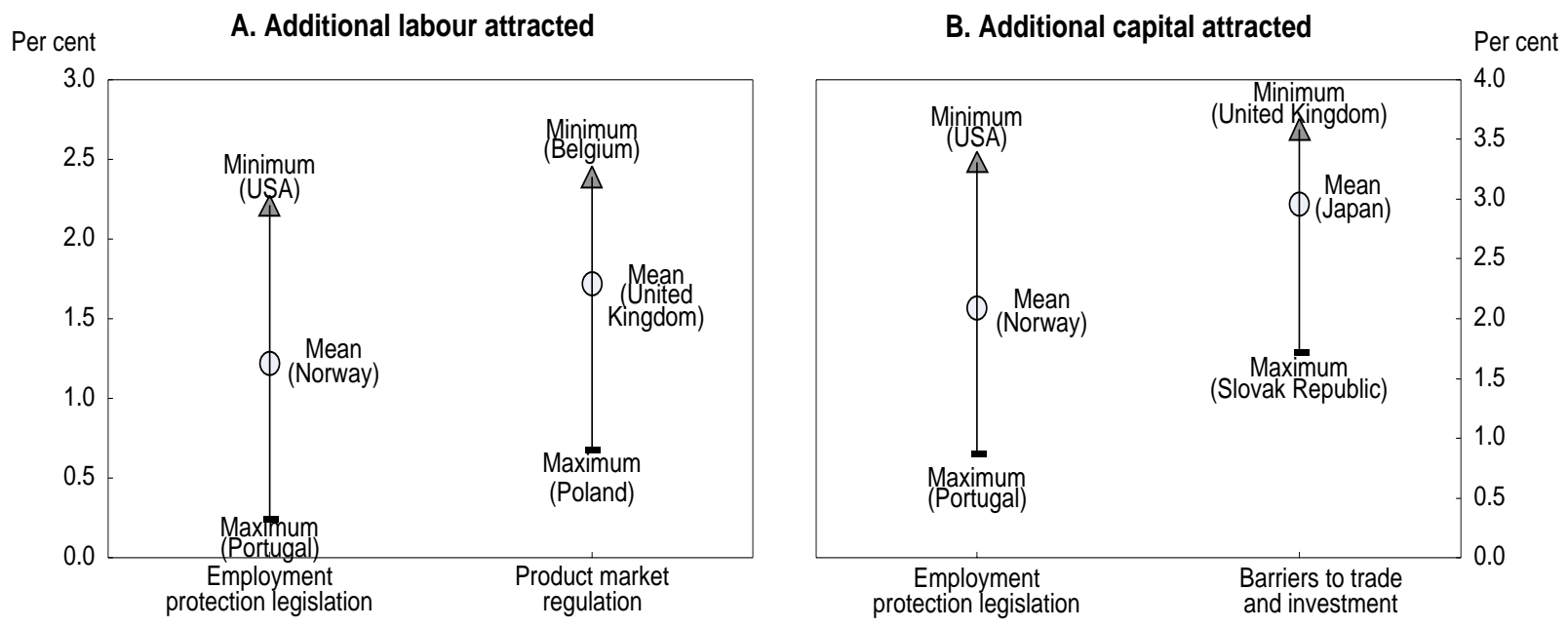

Source: Andrews et al. (2014). 
In Japan, employment protection has contributed to the rise in the share of non-regular workers (such as fixed-term, dispatched and part-time workers) from 16\% of employees in 1985 to $37 \%$ in 2014. Firms hire non-regular workers in part to enhance employment flexibility and avoid the cost of laying off regular workers, who receive high employment protection (2013 OECD Economic Survey of Japan). Indeed, firms that face greater uncertainty in their sales have a higher share of non-regular workers (Matsuura et al., 2011). The government recognised the importance of labour mobility in the Revitalisation Strategy, which calls for a shift "from an excessive employment stability policy to a policy of supporting labour movement to enable individuals to smoothly change jobs, fulfill their potential and play active roles for economic growth". To accomplish this goal, the government should reduce effective employment protection for regular workers, in particular by increasing transparency, accompanied by expanded training opportunities. This would increase investment in R\&D in innovative sectors and enable innovative firms to attract resources. In addition, breaking down labour market dualism would reduce income inequality (2015 OECD Economic Survey of Japan).

\section{Product market regulation}

Competition encourages firms to innovate and develop new markets to stay ahead of competitors. Studies show a significant inverse relationship between product market regulation (PMR) and productivity at the aggregate level (Bouis et al., 2011). Less restrictive PMRs promote: $i$ ) entry by new firms; ii) the effective diffusion of knowledge from both domestic and overseas sources; iii) improved managerial performance; and $i v$ ) private investment in innovation. OECD research shows that a modest cut in the PMR in the energy, transport and communications sectors - corresponding to the difference in regulation between Australia and Austria in 2008 - could boost the level of business R\&D by 5\% (Westmore, 2013).

Less restrictive regulations also enable firms to attract the complementary resources that are needed to implement and commercialise new ideas. For a firm that experienced a $10 \%$ increase in patents over $2002-10$, it is estimated that its work force increased by $2.4 \%$ in the country with the least stringent PMR but by only $0.7 \%$ in the country where it is most stringent (Figure 14). In turn, greater allocative efficiency results in faster productivity and output gains. Moreover, a decrease in PMR is found to have a positive impact on patenting activity. A hypothetical reduction in regulation in Finland in 2008 equivalent to the PMR indicator falling to the sample average in that year (a decline of 0.35 ) is estimated to result in a 3\% rise in patents per capita. In contrast, higher PMR stifles innovation and growth; convergence to the technological frontier will be slower for countries with higher PMR (Westmore, 2013).

Japan's overall PMR indicator was 1.4 in both 2008 and 2013, slightly below the OECD average, but well above the leading OECD economies (Figure 15). The Industrial Competitiveness Enhancement Act cited "over-regulation" as a major distortion limiting Japan's competitiveness. To overcome such obstacles, the government recently re-activated two advisory bodies, which had been dormant between 2009 and 2012, to the Prime Minister:

- The Regulatory Reform Committee (RRC), which consists of 15 members from the business sector, academia and research institutes, presents annual reports on regulatory reform.

- The Council on Economic and Fiscal Policy (CEFP), established within the Cabinet Office in 2001, advises the Prime Minister on economic and fiscal policy, including regulatory reform. It consists of four private-sector experts, five ministers and the Bank of Japan governor.

Regulatory reforms require the full consent of the relevant ministries, which in some cases may use their independence to protect the interests of their clients, making reform a difficult and time-consuming process. Moreover, ministries protecting the interest of producers have been more powerful than those promoting consumers' interests and market competition (Yashiro, 2014). 
Figure 15. International comparison of product market regulation in $2013^{1}$

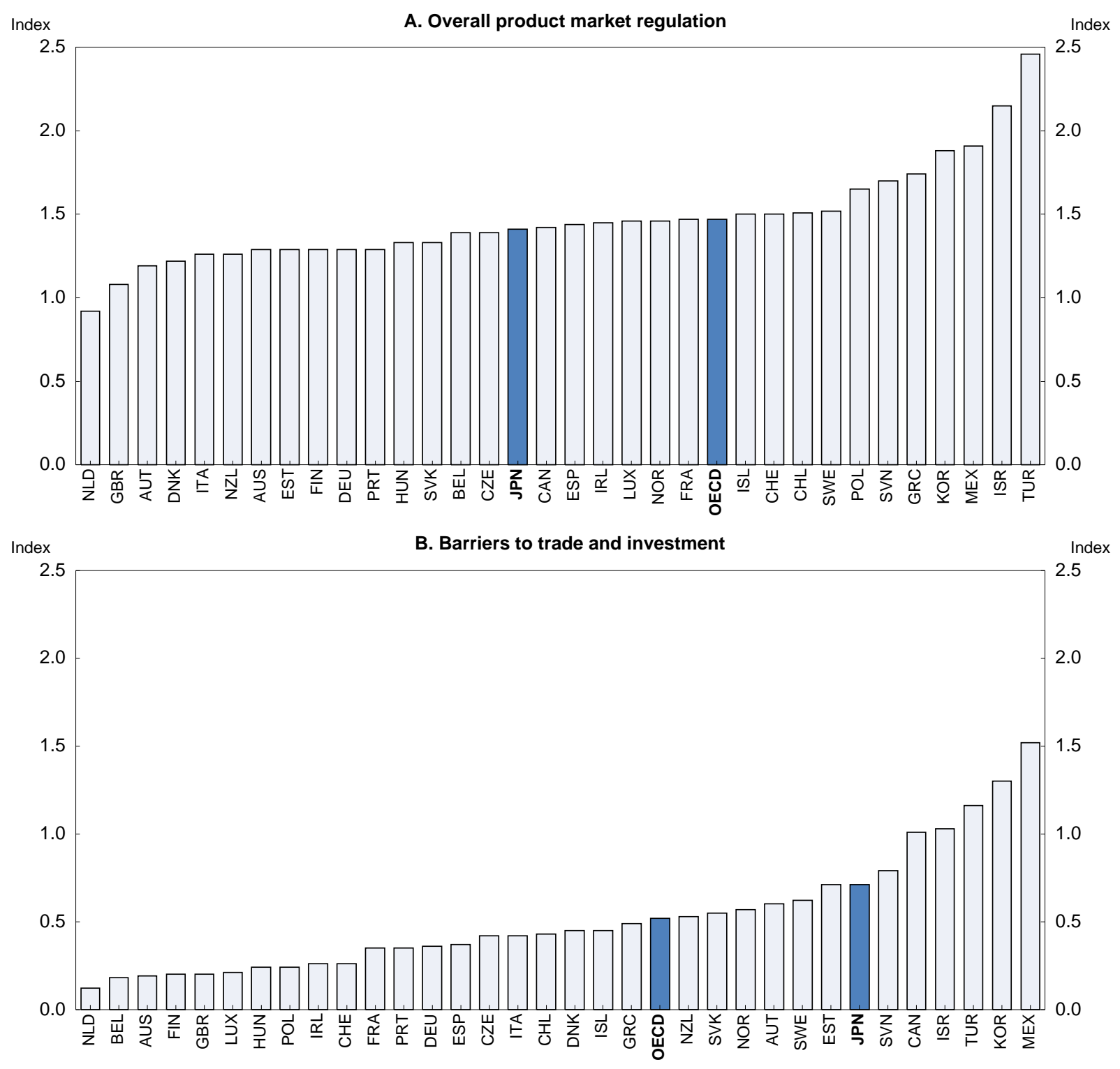

1. The OECD Indicators of Product Market Regulation are a comprehensive and internationally-comparable set of indicators that measure the degree to which policies promote or inhibit competition. Research shows that the indicators have a robust link to performance. The indicator, based on more than 700 questions, ranges from zero (most relaxed) to six (most stringent).

Source: OECD Product Market Regulation Database; Koske et al. (2015).

The government also launched two new initiatives in 2013: the National Strategic Special Zones (Box 2) and the Industrial Competitiveness Council (ICC), which consists of business leaders and ministers and is headed by the Prime Minister. The Council reviews economic and industrial policies, including regulatory reform, and the Revitalisation Strategy. The Council, which aims to make Japan's business environment "the best in the world", could play the role of a productivity commission. 


\section{Box 2. National Strategic Special Zones}

A major feature of Japanese regulatory reform is its use of special zones. The most prominent example is the Special Zones for Structural Reform (SZSR) launched in 2002, which depend on the initiative of local governments. ${ }^{1}$ Of the more than 5725 reform proposals made by local governments, 1235 zones have been created, and 544 reforms in the zones were extended nationwide. The fact that only a fifth of the initial proposals were accepted indicates that opposition to reform, even in limited geographical areas, remains significant, although some proposals were not implemented as they were already allowed by law. The special zones are estimated to have increased private investment by 0.6 trillion yen (0.1\% of 2013 GDP) and employment by 18000 (0.03\%) (Yashiro, 2014). However, interest in the SZSR has waned in recent years.

Nevertheless, the 2013 Japan Revitalisation Strategy includes a new scheme, National Strategic Special Zones. The continued reliance on the special zone approach reflects the importance of social consensus rather than top-down decision making. Given the strong resistance to reforms by powerful ministries and interest groups, social experiments in limited geographical areas are thought to be the only way to achieve significant reforms.

In contrast to the SZSR, the new initiative is driven by the central government. The Council on National Strategic Special Zones is chaired by the Prime Minister and includes the Minister of State for the National Strategic Special Zones, other relevant ministers and private-sector experts. Each of the six new Special Zones has a headquarters, bringing together the Minister of State for the National Strategic Special Zones, the mayor and local business leaders. The headquarters collect regulatory reform ideas from the private sector, which are then examined by the central government's Council. The reforms can be extended nationwide. Once the reforms are agreed, the local headquarters is responsible for implementation. The six zones designated in March 2014 include major urban areas:

- Tokyo area: centre for international business and innovation

- $\quad$ Kansai area (Osaka, Kyoto and Hyogo prefectures): hub for medical innovation and human resources

- $\quad$ Okinawa prefecture: international tourism centre

- $\quad$ Fukuoka City: promotion of start-up businesses through employment reforms

- Yabu City, Hyogo Prefecture: reform centre for agriculture in mountainous regions

- $\quad$ Niigata City: reform centre for large-scale agriculture

The National Strategic Special Zones' main objectives are: i) formation of international centres with the "best environment in the world"; ii) creation of international innovation in health care; and iii) the formation of action centres for agriculture. These objectives are to be achieved through regulatory reforms in urban development, education, employment, medical care and agriculture. The zones are intended to spark private-sector investment. Prime Minister Abe said that they "will strengthen corporate competitiveness, attract investment from abroad and expand employment... The National Strategic Special Zones will be a breakthrough for reform".

The National Strategic Special Zones differ from the SZSR in a number of ways. Most importantly, they are a national project in collaboration with city mayors rather than initiated by local authorities. In addition, they include tax breaks and interest subsidies (Yashiro, 2013). However, the new Special Zones will need more ambitious reforms to make them more successful than previous efforts. For example, the Special Zone for Asian Headquarters was launched in 2011 with an aim of making Japan a centre for international business, by attracting more than 50 corporate headquarters for Asia before 2016. It is thus similar to the new Tokyo Special Zone for Structural Reform. Thus far, though, the 2011 special initiative has attracted only two headquarters (Okubo, 2014).

Moreover, the experience of the Fukuoka special zone shows the challenge of implementing reforms. The mayor of Fukuoka had proposed that employment protection be relaxed in the zone for regular workers in venture businesses less than five years old to promote the growth of new firms. In the end, Employment Consultation Centres providing advice on "Employment Guidelines" were established in three of the zones (Matuso and Yamazaki, 2014).

1. Other examples include the 2011 "Comprehensive Global Strategic Special Zones" to create internationally-competitive business environments and "Comprehensive Special Local Revitalisation Zones" for agriculture, tourism and culture. 
Regulatory reform in Japan was originally focused on lowering business costs by removing obsolete regulations on business activities, such as electricity, trucking and telecommunications, and has led to large benefits (Prime Minister's Office, 2007). Priorities for further reform are retail, energy, transport, business services and public services, such as health and education (2008 OECD Economic Survey of Japan). Reform of public services requires reducing "social regulations", which impose high costs (Yashiro, 2014). For example, firms are not allowed to manage hospitals or clinics, thus protecting small "non-profit organisations" and preventing scale economies and the widening of consumer choice. In addition, the prices of health and long-term care services are fixed, preventing hospitals and long-term care clinics from providing higher quality and more expensive services that some consumers would prefer. The emphasis on egalitarianism prevents competition that would lead to the provision of higher quality services.

Finally, promoting competition in services requires ensuring a level playing field by phasing out the Anti-Monopoly Act's special treatment of SMEs, which play a major role in services. In addition, restrictions on service trade should be liberalised (Figure 16). Of 18 service sectors, Japan's restrictions match or exceed the OECD average in 13 areas including computers, telecommunications, distribution, commercial banking, insurance and air, road, maritime and rail transport.

Figure 16. Japan's services trade restrictiveness index by sector The indices take values between zero and one (the most restrictive) ${ }^{1}$

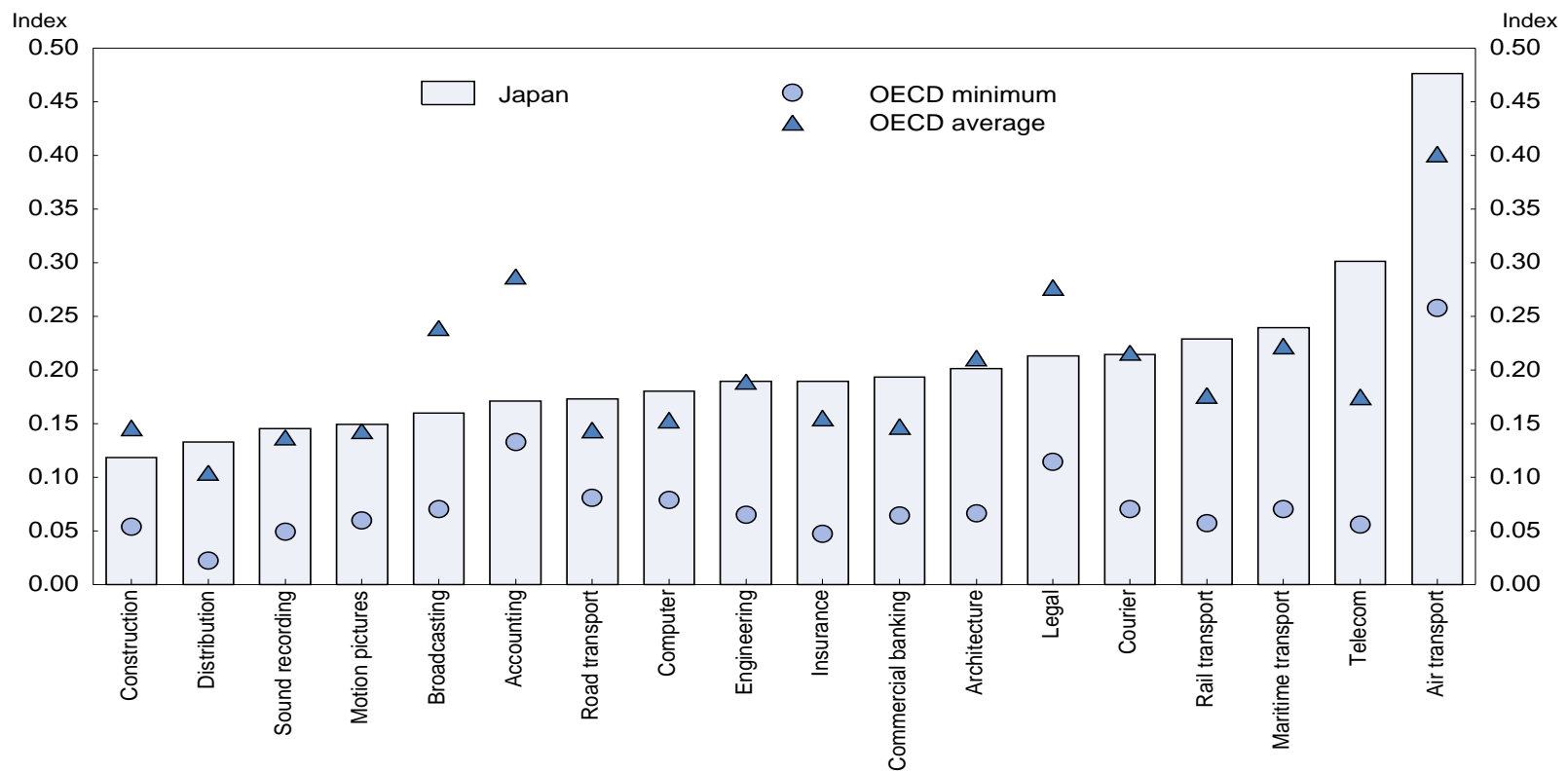

1. The index includes regulatory transparency, barriers to competition, other discriminatory measures, restrictions on movement of people and restrictions on foreign entry. The STRI methodology takes into account different market and trade cost structures across sectors to ensure that they reflect the relative restrictiveness of each sector. Nevertheless, the indices may not be perfectly comparable across sectors. The indicators are for 2013 or the most recent year available.

Source: OECD (2014g).

\section{Promoting international competition}

The liberalisation of barriers to international trade and investment spurs innovation by broadening the scope for knowledge diffusion and technological transfer across borders, either embodied in goods and services or through investment that transmits ideas (Jaumotte and Pain, 2005). The increase in the capital stock in a firm that experienced a $10 \%$ rise in patents ranged from $1.7 \%$ to $3.6 \%$ depending on the level of trade and investment barriers (Figure 14). A number of studies show that foreign firms operating in Japan have higher management efficiency and productivity than their Japanese counterparts (Urata, 2005). International openness thus promotes competition and more efficient resource allocation; firms that cannot 
compete in the global market downsize, while those that can, expand production. The benefits of international openness are maximised by pro-competition domestic product market regulations.

Investment in Japan offers a number of advantages, including a large domestic market, a skilled work force, its location as a gateway to Asia, low-cost capital, and the opportunity to work with high-tech partners and tap Japanese R\&D (EBC, 2014). These factors explain why Japan ranked tenth in the world in 2011 in UNCTAD's "Inward FDI Potential Index". Nevertheless, the stock of inward FDI in Japan has stayed below 4\% of GDP since 2008, the lowest in the OECD. Moreover, it is only 15\% of Japan's stock of outward FDI, compared to ratios between $60 \%$ and $90 \%$ for other G7 countries, reflecting in part Japan's high barriers to trade and investment (Figure 15, Panel B). In addition, public opinion is less favourable to FDI inflows, which is sometimes viewed as a threat (Urata, 2005).

\section{Policies to promote inflows of foreign direct investment}

The Japan Revitalisation Strategy set a target of doubling the stock of inward FDI from 18 trillion yen in 2012 to 35 trillion yen in 2020, echoing the 2003 plan to double FDI over five years. The government's Expert Group on FDI in Japan held meetings in early 2014 with foreign firms to identify the factors that limit FDI inflows to Japan (Expert Group of the Cabinet Office, 2014 and EBC, 2014). The overriding concern is the need for harmonisation with global systems to address the problem of low profitability and high costs in Japan and to improve living conditions for expatriates. A number of specific issues were cited:

- Corporate mergers and acquisitions (M\&As): M\&As, a key channel for FDI, are low in Japan. A 2007 law aimed to facilitate "triangular mergers", in which a foreign firm can acquire a Japanese company through a merger of its Japanese subsidiary and the Japanese target company. The Japanese subsidiary is allowed to use shares issued by its foreign parent to purchase the shares of the Japanese target company, which disappears. However, a "business continuation" criterion is applied, which effectively means that only companies that already have operations in Japan can use this approach. Consequently, triangular mergers have remained virtually unused (EBC, 2014).

- The tax system: a high corporate income tax rate discourages FDI inflows (Arnold et al., 2011). Even with the planned reduction to 31.3\% in FY 2016 (see the 2015 OECD Economic Survey of Japan), Japan's rate will remain much higher than in other Asian economies, such as Hong Kong, China (16\%), Singapore and Taipei, China (17\%), Korea (24\%) and China (25\%).

- Corporate governance: Japan's corporate governance framework lags behind global standards (see above). The lack of clarity and accountability discourages potential investors (EBC, 2014).

- The regulatory environment: Unclear administrative practices and unique and rigid standards for certifying consumer goods in Japan are a deterrent to FDI inflows (EBC, 2014). Procedures for starting a business are long and complicated.

- Employment: Japan needs to enhance the flexibility of employment and termination rules (see below) to attract FDI. The lack of mid-career mobility makes it difficult for foreign firms in Japan to secure experienced workers. In addition, there is a shortage of English-language skills.

- Entry of foreign workers: Given that FDI is also facilitated by the movement of people, rules that restrict the entry of workers can discourage foreign investors. For example, a worker in a field that is different from his or her educational background must prove they have ten years of experience in the industry to obtain a visa.

Foreign companies also cite the importance of free trade agreements, as liberalising trade promotes FDI as well (Thangavelu and Findlay, 2011). While Japanese tariffs are low, the key obstacles are nontariff barriers, including the regulatory environment. According to the European Business Council in Japan, unique product specifications and certification processes raise costs, requiring some EU companies to run 
Japan-only production lines (EBC, 2014). Japan has signed 15 Economic Partnership Agreements (EPAs) since 2002, primarily with ASEAN countries (Table 2). Together, they cover less than a quarter of Japan's trade. The Japan Revitalisation Strategy seeks to raise the share of Japan's trade with countries with which it has an EPA or FTA from $19 \%$ in 2012 to $70 \%$ by 2018 . This requires agreements with larger trading partners, such as the United States, China and the EU, which is to be completed in 2015. Japan decided in 2013 to join the Trans-Pacific Partnership (TPP) negotiations to create a 12-nation free trade agreement including North America, Australia, New Zealand and Chile. The countries agreed, in principle, to eliminate all tariffs. The TPP is a key priority as it has the potential to bring important, long-lasting benefits to Japan.

\section{The importance of agricultural reform in Japan}

The benefits from EPAs depend on the extent to which Japan opens its agricultural sector during the negotiations, thereby enabling Japan to obtain concessions on its manufactured exports (2013 OECD Economic Survey of Japan). The Plan for Creating Dynamism Through Agriculture, Forestry and Fisheries and Local Communities aims at enhancing the competitiveness of farmers, enabling the agricultural sector to become competitive, and as a result, able to cope with high-level EPAs. Such agreements require cutting border measures, which isolate farmers from international competition. Border measures, including the tariff on rice, contribute to the high level of assistance: the Producer Support Estimate was 54\% in Japan in 2011-13, three times the OECD average (Figure 17). Prices received by farmers are double world market prices. Such assistance imposes heavy burdens on taxpayers and consumers. Indeed, consumption spending on agricultural commodities was 1.8 times their value at border prices over 2011-13 (OECD, 2014a). In other words, higher prices boosted consumer spending on agricultural products 1.8 times.

Table 2. Japan's Economic Partnership Agreements

\begin{tabular}{|c|c|c|c|c|c|}
\hline \multirow[b]{3}{*}{ Singapore } & \multirow[t]{2}{*}{ Took effect in: } & \multicolumn{2}{|c|}{$\begin{array}{c}\text { Share of exports in } 2014 \text { in per } \\
\text { cent }\end{array}$} & \multicolumn{2}{|c|}{$\begin{array}{c}\text { Share of imports in } 2014 \text { in } \\
\text { per cent }\end{array}$} \\
\hline & & Total & Agriculture & Total & Agriculture \\
\hline & 2002 & 3.1 & 1.4 & 1.0 & 0.9 \\
\hline Mexico & 2005 & 1.6 & 0.2 & 0.5 & 1.3 \\
\hline Malaysia & 2006 & 2.0 & 1.7 & 3.6 & 0.9 \\
\hline Chile & 2007 & 0.2 & 0.0 & 1.0 & 6.6 \\
\hline Thailand & 2007 & 4.5 & 4.7 & 2.7 & 4.3 \\
\hline Indonesia & 2008 & 2.1 & 2.5 & 3.1 & 3.9 \\
\hline Brunei & 2008 & 0.0 & 0.0 & 0.5 & 0.0 \\
\hline Philippines & 2008 & 1.4 & 0.8 & 1.2 & 2.3 \\
\hline ASEAN $^{1}$ & 2008 & 15.2 & 15.9 & 14.2 & 14.2 \\
\hline Switzerland & 2009 & 0.4 & 0.1 & 0.9 & 0.6 \\
\hline Vietnam & 2009 & 1.7 & 4.5 & 1.9 & 1.7 \\
\hline India & 2011 & 1.2 & 1.0 & 0.9 & 1.0 \\
\hline Peru & 2012 & 0.1 & 0.0 & 0.2 & 1.1 \\
\hline Australia & 2014 & 2.1 & 0.7 & 5.9 & 13.4 \\
\hline Mongolia ${ }^{2}$ & & 0.0 & 0.1 & 0.0 & 0.0 \\
\hline Total & & 20.4 & 17.7 & 23.4 & 38.0 \\
\hline
\end{tabular}

1. Includes Cambodia, Laos and Myanmar, in addition to the other ASEAN countries shown individually.

2. Signed in February 2015.

Source: OECD International Merchandise Trade Statistics Database.

Productivity in land-intensive agriculture is low, reflecting the small average farm size of only 2 hectares, compared to the European Union (14 hectares) and the United States (170 hectares) (MAFF, 2012). The government estimates that land productivity on rice farms of 10 to 15 hectares is double that on farms of 1 to 2 hectares, the current norm. The prevalence of small farms reflects the production quota 
system, subsidies that make small-scale farming profitable and the complex web of laws governing land ownership, transfer and taxation (Jones and Kimura, 2013).

Figure 17. The Producer Support Estimate ${ }^{1}$ for Japan is the second highest in the OECD

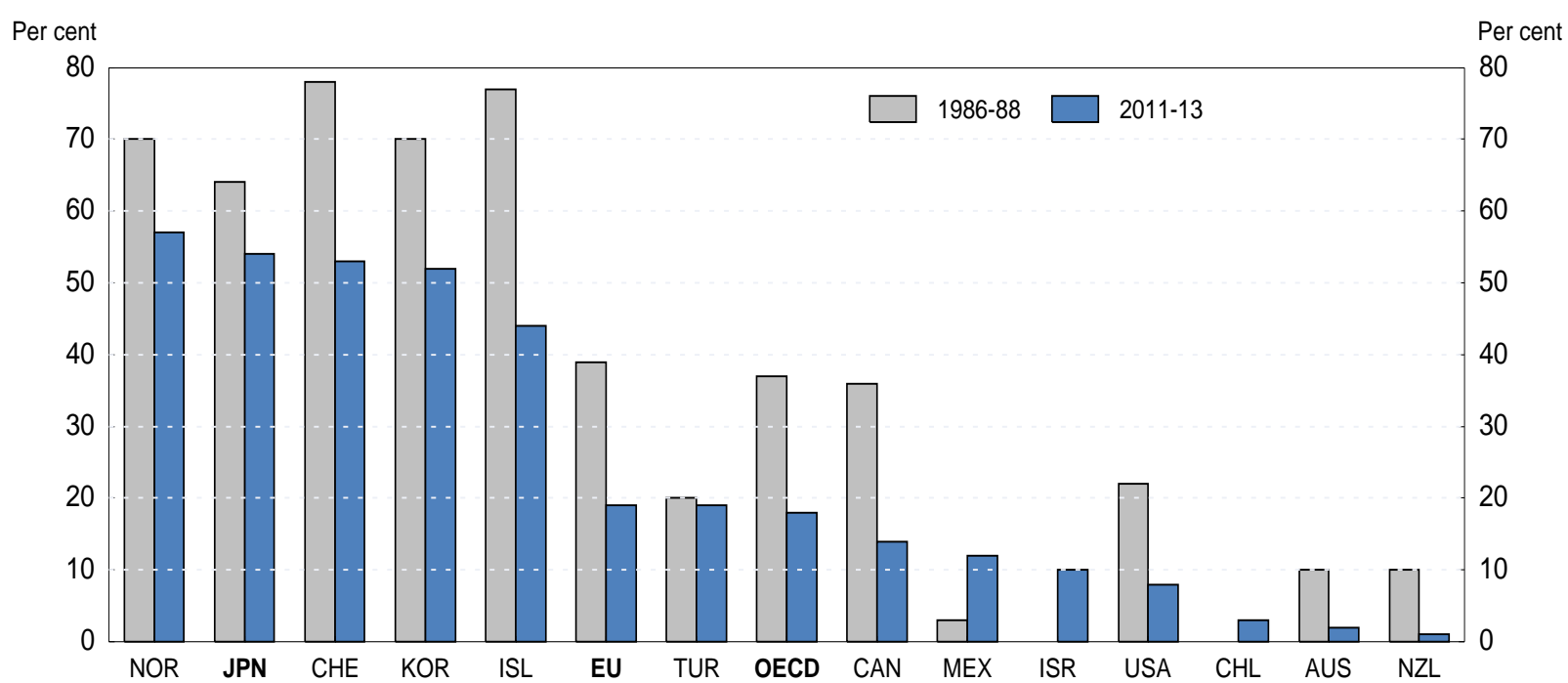

1. Producer support is the annual monetary value of gross transfers from consumers and taxpayers arising from policies that support agriculture, regardless of their nature, as a per cent of the value of gross farm receipts. Countries are ranked according to their 2011-13 levels. Chile, Israel and Slovenia are excluded from the OECD total in 1986-88. The EU figure is the EU12 for 1986-88 and the EU27 for 201-13.

Source: OECD PSE/CSE Database 2014.

The Revitalisation Strategy set an ambitious target of doubling the income of farmers and farming communities within ten years, in part by doubling exports to 1 trillion yen by 2020. A similar 2007 initiative failed to raise exports, reflecting in part the 2008 global financial crisis and the 2011 Great East Japan Earthquake. In 2014, agriculture, forestry and fishery exports increased by $11.1 \%$ in value terms to a record high 612 billion yen. Several reforms have been announced to help achieve the Strategy's goal. First, regional government-supported institutions were established in 2014 to promote farm consolidation by leasing land from farmers and renting it to business farmers and new entrants. Farm consolidation is essential to achieve the government's goal of reducing the cost of rice production by business farmers by $40 \%$. However, the impact of the new policies will be limited by existing policies, such as price support, which discourage farm exit. Farmers hang onto their land as they can still make a profit, given high rice prices, and many hope to make a profit by selling their land for residential or other uses. Consequently, a previous farmland consolidation organisation operating in all prefectures only leased around 32000 hectares in 2011 ( $0.6 \%$ of Japan's total farmland).

Second, the rice production adjustment programme introduced by the government in 1970 will be phased out by FY 2018. Direct payments for rice will be abolished in 2018. However, subsidies for manufacturing and feed rice, and other crops, such as wheat and barley, were increased with an aim to fully utilise paddy land and raise food self-sufficiency. Such an approach will keep the rice price high by limiting its supply. Commodity-specific support accounts for around $90 \%$ of producer support in Japan, compared to $32 \%$ in the European Union (OECD, 2014a). Support to farmers should be decoupled from the production of specific commodities and, over time, phased out. As for border measures, the government is participating in TPP negotiations, taking into account the April 2013 Diet resolution, which called on the government to give top priority to protecting the categories of rice, wheat and barley, beef and pork, dairy products and sugar and starch crops. 
The reforms underway, however, fall far short of what is needed to achieve the government's goals and create an open competitive environment for farmers. The thriving specialist livestock and horticulture industries demonstrate that many Japanese farmers have the potential to be internationally competitive and respond to market opportunities (Jones and Kimura, 2013). Indeed, vegetables, a labour-intensive sector that receives little public support and is not necessarily large-scale, increased its share of agricultural output from $9 \%$ in 1960 to $27 \%$ in 2013 . To create a competitive agricultural sector, more ambitious reforms are required:

- Shift away from commodity-specific payments, which push farmers into activities where they are not competitive. Instead, farmers should have the freedom to make their own production decisions in response to market demands. Reducing the subsidies for the diversion crops would lower the price of rice toward the world price.

- Phase out subsidies based on the cost of production, as they perpetuate inefficient production and hinder farm consolidation, in favour of payments decoupled from production. Decoupled payments, such as those based on environmental services, are more efficient in raising farm income, in addition to being more transparent. Shifting from supporting farm income through subsidies and import barriers to a system of direct income support for farmers would lower the overall cost of agricultural support in Japan, according to an OECD study (OECD, 2009).

- Unravel the policy settings that impede farm consolidation to move toward the goal of increasing the ratio of farmland used by business farmers to $80 \%$ by 2023 . Land markets should become more dynamic, notably by lifting obstacles to transactions. The prohibition on non-agricultural corporations owning farmland should be abolished to leave open all options for attracting labour, capital and technology to agriculture. This may help reduce the large amount of idle farmland, despite other obstacles.

- Reform the role of the Central Union of Agricultural Co-operatives (JA Zenchu) to strengthen market forces in agriculture. The Regulatory Reform Committee has proposed reforms reducing the JA Zenchu's administrative role, at the same time securing the independence and revitalisation of local agricultural co-operatives.

Bold reforms to revitalise the agriculture sector should begin promptly, given the urgent need to boost Japan's growth potential and the advancing age of farmers. Indeed, in 2010, the average age of rice farmers was 68.5 and $56 \%$ were over 70 , while another $36 \%$ were between 50 and 70 (Figure 18). Only $8 \%$ were under age 50. In addition, the high level of farm household income, which exceeds that of non-farm households, means that farmers have the resilience and capacity to cope with reform.

Figure 18. Japan's farm workforce is elderly: the age distribution of rice farmers in 2010

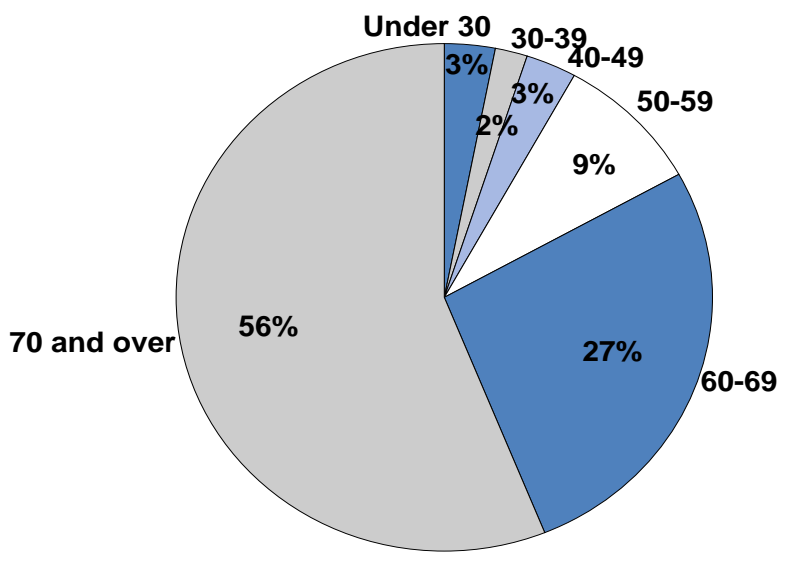


Reform also requires addressing the issue of food security, which is often confused with food selfsufficiency, making agricultural reform very difficult politically. Despite the high level of support, agricultural output is falling and food self-sufficiency declined from $79 \%$ in 1960 to $39 \%$ in 2013 in calorie terms. The government aims to raise it to $50 \%$ by 2020 . Further opening the agricultural sector, though, would lower food self-sufficiency, at least in the short run. It is essential to adopt a multi-faceted approach to food security that includes: $i$ ) a more competitive domestic agricultural sector; $i$ ) diversified sources of imports; iii) sufficient emergency food reserves; and $i v$ ) the conservation of an adequate agricultural resource base (2013 OECD Economic Survey of Japan). Introducing provisions in EPAs with food exporters to ensure food supply is one way to establish long-term supply relationships and enhance food security.

\section{Measures to improve Japan's innovation system}

Japan's gross domestic expenditure on R\&D, which has remained around $3 \frac{1}{2}$ per cent of GDP since 2005, was the fifth highest in the OECD in 2012. Moreover, the business sector accounts for three-quarters of the outlays, one of the highest shares in the OECD area. Business R\&D is particularly important as it has the greatest impact on TFP growth (Westmore, 2013). Despite the high business R\&D intensity, TFP growth in Japan has been well below the OECD average in recent years (Figure 19), as noted above. One reason may be that only $30 \%$ of Japanese patents have been exploited internally and less than $10 \%$ were licensed to others (OECD, 2008). In addition to framework conditions, increasing the return on R\&D requires better bridging to innovation by ensuring adequate human capital in science and engineering, upgrading the quality of universities and strengthening their links with firms, expanding international collaboration in innovation, and improving the framework for public support for R\&D.

Figure 19. Total factor productivity growth and business R\&D intensity 1995-2013

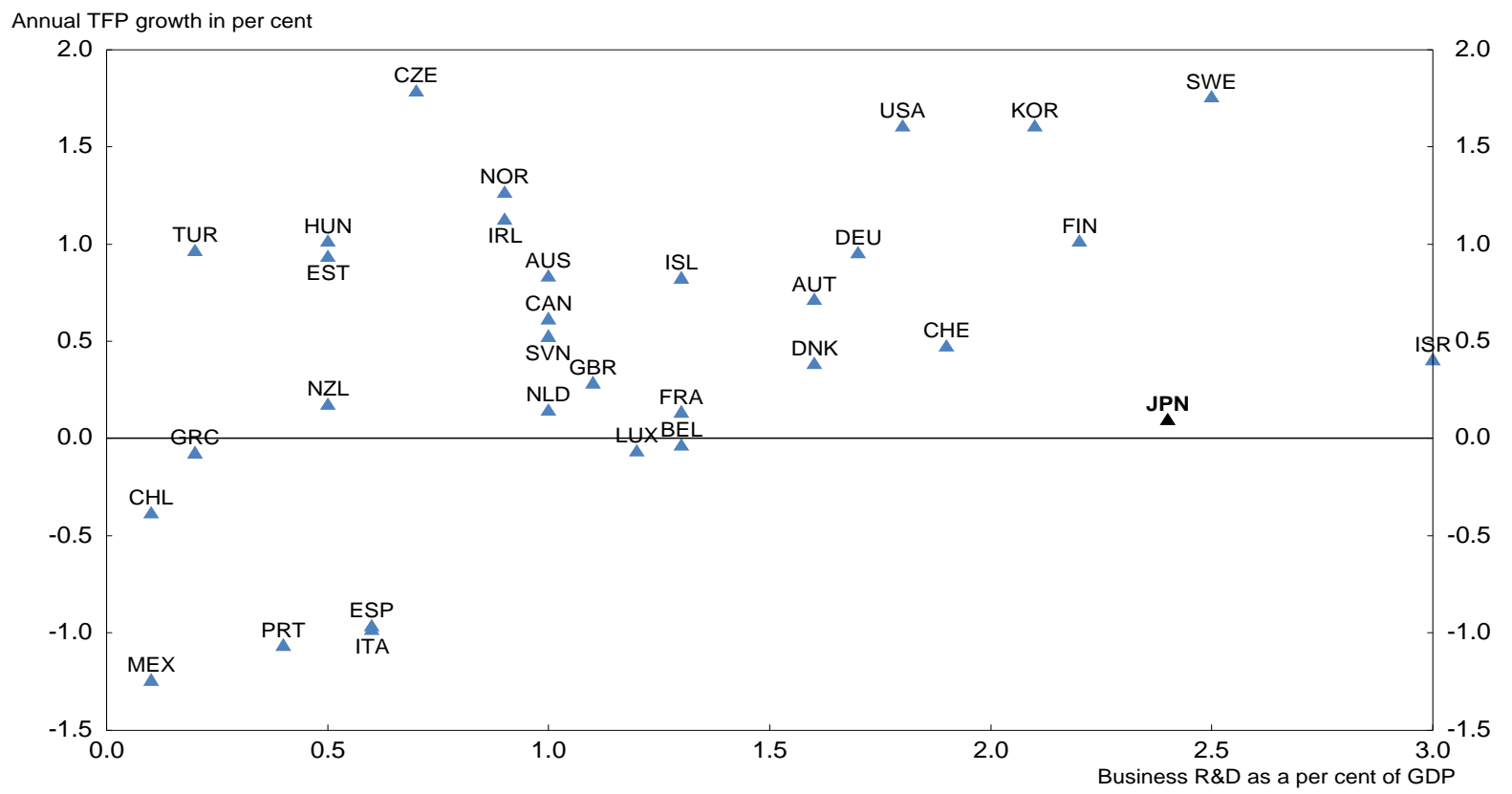

Source: OECD Economic Outlook No. 96; OECD Main Science and Technology Indicators.

\section{Ensuring adequate human capital in science and engineering}

Japan is well known for its educational achievements. The share of the adult population with a tertiary education is the third highest in the OECD area (Figure 20). Among 15-year-olds, Japan had the thirdhighest score in science in the 2012 PISA tests (OECD, 2013d) and the proportion of its top performers is 
the highest in the OECD. However, like some other OECD countries, Japan faces labour shortages in some key sectors due to a decline in the number of science and engineering majors in universities during the past 25 years. By 2007, there were 4.5 job offers for each graduate in fields like electronic machinery, well above the 1.5 nationwide average. The doctoral graduation rate in science and engineering is well below the OECD median at $22 \%$ of all doctorates.

Figure 20. Comparative performance of national science and innovation systems in 2014

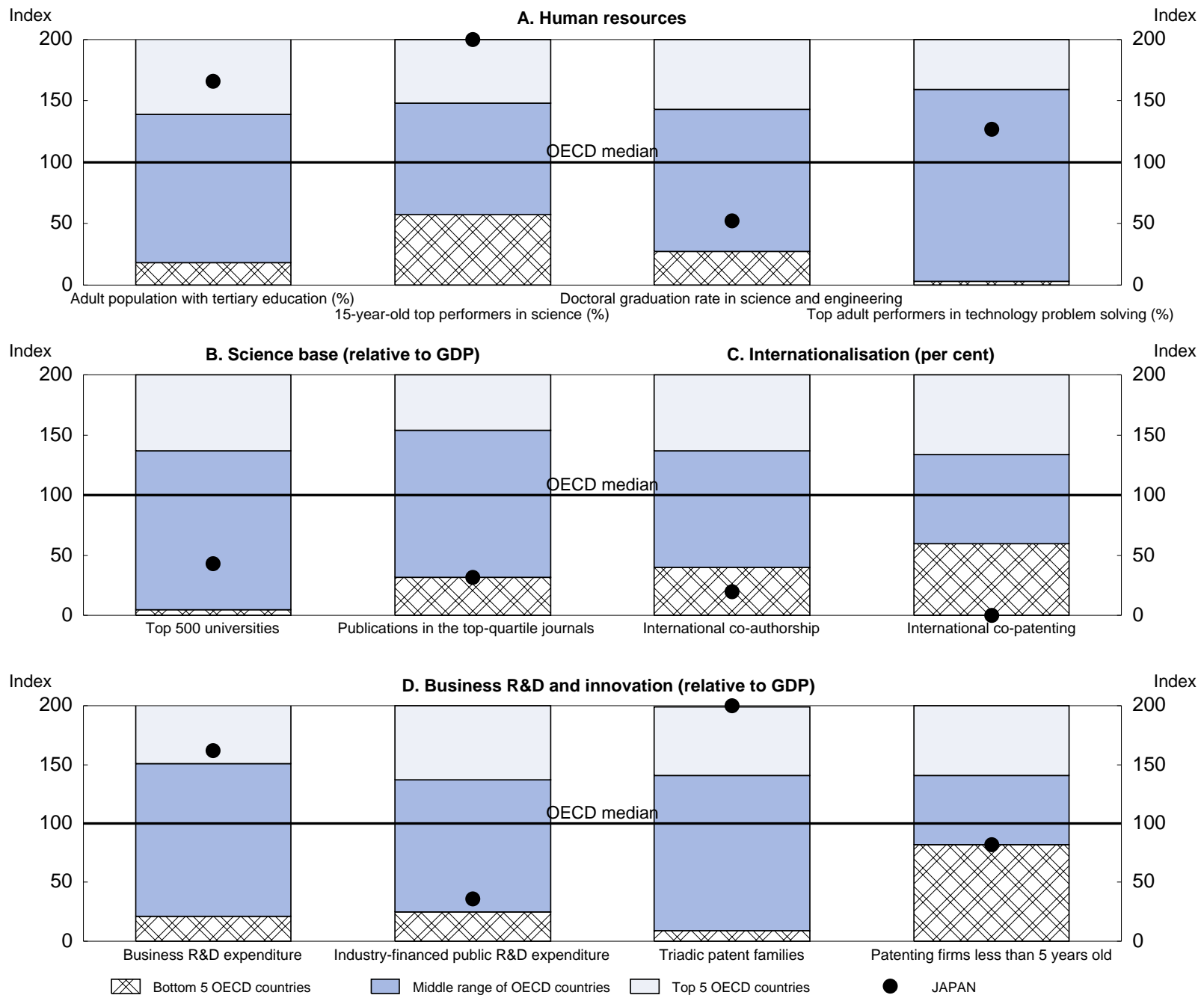

Note: Normalised index of performance relative to the median values in the OECD, which are set at 100 . The top performer is set at 200 and the lowest at zero. For example, the fifth-highest performer in the case of the "Top 500 universities" had a score of 137 relative to the OECD median, while the fifth lowest had a score of 5 . Japan, with a score of 43 , was in the middle range.

Source: OECD (2014f).

\section{Upgrading the quality of universities and strengthening their links with firms in R\&D}

Although total spending at the tertiary level in Japan is close to the OECD average, the number of Japanese universities ranked in the top 500 in the world (relative to GDP) was well below the OECD median in 2014 (Figure 20, Panel B), suggesting scope to improve quality. Japan's 2014 reform plan is dividing universities into three categories. The 22 universities chosen for the top category are expected to 
compete with the top institutions of higher learning in the world. In addition to this reform, promoting internationalisation and competition between institutions may help to improve quality.

Internationalising the university sector by increasing the share of foreign students and attracting leading foreign tertiary institutions to Japan would improve its performance (2011 OECD Economic Survey of Japan). In 2008, when the share of foreign students in Japanese tertiary institutions was 3.2\%, the government launched the Global 30 project with 13 universities with an aim of increasing the number of foreign students to 300000 (about $10 \%$ of total tertiary enrolment) by 2020 . Nevertheless, the share was only $4 \%$, in 2012 , half of the OECD average of $8 \%$. Attracting accredited foreign providers to the tertiary sector would also help stimulate competition and raise the competitiveness of Japanese universities by introducing best practices. However, the number of branch campuses of foreign universities in Japan fell from around 40 in the early 1990s to five at present. Meanwhile, young Japanese are becoming increasingly inward-looking (Expert Group of the Cabinet Office, 2014). For example, the number of Japanese students studying at top universities overseas is lower than that of their Chinese and Korean counterparts.

Strengthening competition depends in part on increasing transparency about the quality of tertiary institutions and their results by providing detailed information, including on the labour market outcomes of their graduates. In addition, the government could strengthen competition by raising the share of funding that is linked to a university's performance, which is currently only around one-fifth. As the expanding supply of tertiary education and the falling number of high school graduates have converged, demographic trends provide an opportunity to enhance competition and raise quality. The number of 18 -year-olds, which peaked at 2.05 million in 1992, dwindled to about 1.2 million by 2012. During that time, the number of four-year universities rose from 523 to 783 , of which about $90 \%$ are private. Consequently, nearly half of private universities have excess capacity and around $40 \%$ are operating in the red. As the number of high school graduates continues to fall, tertiary institutions will face rising pressure to maintain enrolments. Ensuring adequate information through an accreditation and quality assurance system is essential to ensure that downsizing results in the restructuring, merger and closure of the weakest institutions (Jones, 2011).

Relaxing regulations on tuition, enrolment caps and the requirement that the government approve programme changes would also promote competition. The government sets a standard tuition level for national universities, but allows them to charge up to $20 \%$ more. However, almost all universities charge the standard amount, reflecting concern that higher tuition would be offset by a cut in government grants. As a result, tuition fees are largely unrelated to the quality of education, its cost or the labour outcomes of its graduates. The undifferentiated level of tuition fails to encourage the most efficient use of resources. Universities should be allowed to set tuition fees, with any changes not offset by government grants, while at the same time expanding student loan programmes to ensure access for all qualified students.

Higher-quality universities could make a larger contribution to innovation. Of business-financed R\&D spending, only $0.5 \%$ in 2013 was carried out at universities, indicating weak linkages between academia and the business sector (Table 3). Similarly, only $2.6 \%$ of research performed at universities was funded by firms. Moreover, spending on R\&D performed in universities increased by only $12 \%$ (adjusted for inflation) in Japan between 2000 and 2012, compared to 50\% in Germany and 59\% in the United States. While universities employ a majority of Japan's PhDs in natural sciences, they financed only $5.9 \%$ of R\&D in 2013. The role of universities could be strengthened by raising the share of government R\&D funding that is competitively financed. An increased university role in R\&D should be accompanied by greater university-business co-operation in a range of areas, including curriculum (Jones, 2011). A larger university role in $R \& D$ may also boost the share of basic research in total $R \& D$, which is the third lowest in the OECD, even though Japan is at the technology frontier in many fields. 
Table 3. Flows of R\&D funds in 2013

A. R\&D funding

\begin{tabular}{|c|c|c|c|c|c|c|c|}
\hline \multirow[b]{2}{*}{ Source of funding } & \multicolumn{7}{|c|}{ Allocation of R\&D spending by sector performing it } \\
\hline & \multicolumn{2}{|c|}{$\begin{array}{c}\text { Share of total R\&D } \\
\text { spending }\end{array}$} & \multicolumn{2}{|c|}{ Government } & Universities & $\begin{array}{l}\text { Business } \\
\text { enterprises }\end{array}$ & Total \\
\hline Government $^{1}$ & \multicolumn{2}{|l|}{18.1} & \multicolumn{2}{|c|}{54.4} & 40.2 & 5.4 & 100.0 \\
\hline Universities & \multirow{2}{*}{\multicolumn{2}{|c|}{5.9}} & \multicolumn{2}{|c|}{0.6} & 99.3 & 0.1 & 100.0 \\
\hline Business enterprises & \multirow{2}{*}{\multicolumn{2}{|c|}{$\begin{array}{r}75.5 \\
0.5\end{array}$}} & \multirow{2}{*}{\multicolumn{2}{|c|}{$\begin{array}{l}0.6 \\
9.6\end{array}$}} & \multirow{2}{*}{$\begin{array}{l}0.5 \\
1.6\end{array}$} & 98.9 & 100.0 \\
\hline Foreign sources & & & & & & 88.8 & 100.0 \\
\hline \multicolumn{8}{|c|}{ B. Sector performing R\&D } \\
\hline \multirow[b]{2}{*}{ Sector performing R\&D } & \multicolumn{7}{|c|}{ Funding source for R\&D performed } \\
\hline & $\begin{array}{c}\text { Share of total } \\
\text { R\&D } \\
\text { performed }\end{array}$ & Gov & ernment & Universities & $\begin{array}{l}\text { Business } \\
\text { enterprises }\end{array}$ & $\begin{array}{l}\text { Foreign } \\
\text { sources }\end{array}$ & Total \\
\hline Government $^{1}$ & 10.4 & & 94.5 & 0.3 & 4.7 & 0.5 & 100.0 \\
\hline Universities & 13.5 & & 54.1 & 43.2 & 2.6 & 0.1 & 100.0 \\
\hline Business enterprises & 76.1 & & 1.3 & 0.0 & 98.1 & 0.6 & 100.0 \\
\hline
\end{tabular}

1. Includes private non-profit institutes.

Source: OECD R\&D Statistics Database.

The government has launched technology licensing organisations (TLOs), which are corporations that obtain patents for university research results and license the technology to private firms, thereby promoting academia-industry co-operation. The new businesses created by technology licensing return part of the profit to the universities, thus funding further research. The government assists TLOs through subsidies and by waiving patent fees. While Japan has 38 TLOs approved by the government, their role is relatively small, as only \$24 million in royalty income was generated in 2010 , about $1 \%$ of the $\$ 2.4$ billion in the United States (Table 4). The number of patents held by universities has not increased since 2010.

Table 4. University-industry collaboration in selected countries in 2010

\begin{tabular}{lrccccc}
\hline & $\begin{array}{c}\text { Number } \\
\text { of } \\
\text { patents }\end{array}$ & $\begin{array}{c}\text { Number of } \\
\text { technology } \\
\text { transfers }\end{array}$ & $\begin{array}{c}\text { Royalty } \\
\text { income }\end{array}$ & $\begin{array}{c}\text { Number of sponsored/ } \\
\text { collaborative research } \\
\text { projects }\end{array}$ & $\begin{array}{c}\text { Amount of sponsored/ } \\
\text { collaborative } \\
\text { research projects }\end{array}$ & $\begin{array}{c}\text { Number } \\
\text { of start- } \\
\text { ups }\end{array}$ \\
\cline { 2 - 7 } Japan & 8675 & 4968 & 24 & 21600 & 469 & 47 \\
United States & 13397 & 4284 & 2400 & - & 4300 & 651 \\
United Kingdom & 2258 & 5082 & 45 & 28576 & 1245 & 268 \\
\hline
\end{tabular}

1. In million US dollars.

Source: Nishimura (2013).

In addition, the number of collaborative research projects between universities and firms has stagnated in recent years. While the number is significant at 21600 in 2010, many are small-scale projects. Consequently, the total spent on collaborative projects was $\$ 469$ million (Table 4), only about one-tenth the amount in the United States and one-third that in the United Kingdom. The government hopes to expand large-scale collaborative projects to promote the commercialisation of such projects. Indeed, after reaching 252 in 2005, the number of start-ups from university-business collaboration fell to 47 in 2010. The government is also trying to enhance the role of government research institutes (GRIs). Under the new Innovation National System (the Amari Plan), they are to play a bridging role to promote exchanges between business, academia and the government. 
ECO/WKP(2015)79

\section{Promoting open innovation in global networks and international collaboration}

In recent years, there has been a trend toward "open innovation in global networks", in which firms increasingly collaborate with external partners, such as suppliers, customers and other companies, both at home and abroad (OECD, 2008). Open innovation thus provides a much broader base of ideas and technologies. However, Japanese firms have not embraced open innovation to the same extent as their foreign peers, reflecting concerns about losing technology to competitors (Motohashi, 2013). Japan ranked $16^{\text {th }}$ out of 24 OECD countries in an OECD study on the share of external knowledge sources for innovation over 2008-10 (OECD, 2013d). Only $0.5 \%$ of the R\&D carried out in Japan in 2013 was financed from abroad (Table 3), one of the lowest shares in the OECD, indicating that linkages with foreign firms and institutions are relatively weak, and few foreign researchers come to Japan. According to a study of 16 countries, the share of immigrant scientists in Japan is among the lowest (Franzoni et al., 2012). Consequently, the level of international co-authorship of academic papers is also among the lowest in the OECD area (Figure 20, Panel C). As noted above, increasing openness to trade and investment and promoting the internationalisation of universities would enhance Japan's participation in world R\&D networks. The government has shown limited commitment to the globalisation of R\&D (Motohashi, 2013).

The number of Japanese applications for triadic patent families (per GDP) during 2009-11 was the highest in the OECD area (Figure 20, Panel D). Despite the numerical success, an OECD study ranked the quality of Japanese patents at $17^{\text {th }}$ of 21 member countries, based on 12 indicators (Squicciarini et al., 2013). Greater international collaboration could help improve their quality, as the level of international copatenting in Japan was the lowest in the OECD (Figure 20, Panel C).

\section{Improving the framework for public support for $R \& D$}

Government science and technology spending declined in FY 2013 for the first time in a decade, making it difficult to boost government R\&D spending to $1 \%$ of GDP, an objective in the $4^{\text {th }}$ Science and Technology Basic Plan (FY 2011-15). The current plan aims to shift from a technology-driven approach to an issue-driven approach, focusing on: $i$ ) reconstruction from the Great East Japan Earthquake; ii) green innovation; and iii) "life innovation" to improve health and nursing care. The government also wants to promote greater interaction between $\mathrm{R} \& \mathrm{D}$ activities in universities, government and the business sector, in part by enhancing the labour mobility of researchers between sectors. The third Science and Technology Basic Plan for FY 2006-10 proposed enhancing such mobility by expanding the use of fixed-term contracts and performance evaluation at universities and by requiring researchers to change their organisational affiliation at least once after graduation before obtaining a permanent position. However, labour mobility remains low, reflecting the reliance on long-term, open-ended contracts. The government is planning to promote labour mobility by allowing researchers to have cross-appointments in universities, GRIs and firms.

To improve co-ordination and eliminate the "silos" between ministries and sectors, the Council on Science and Technology Policy was reorganised in May 2014 as the Council on Science, Technology and Innovation (CSTI). It will collaborate with other councils, including the Industrial Competitiveness Council, which plays a key role in the Revitalisation Strategy. CSTI decisions will also be endorsed by the Cabinet, making them binding on all ministries. A budgeting committee, including officials from relevant ministries, was established under the CSTI. In addition, a new programme, Impulsing PAradigm Change through Disruptive Technologies (ImPACT), was created to promote high-risk and high-impact R\&D.

Public support for business-sector R\&D is justified by market failures that keep R\&D spending below the socially-optimal level. Business R\&D in Japan fell 12\% in inflation-adjusted terms in 2009 and remained 6\% below its pre-crisis level in 2011 (OECD, 2013d). Public support can be classified as tax incentives, a non-discriminatory tool that reduces the marginal cost of R\&D for firms, and direct support 
(Figure 21). Tax incentives have been found to be effective: according to an OECD study, a $6 \%$ increase in the generosity of R\&D tax incentives boosts the level of R\&D by about $6 \%$ in the long run. However, the impact is less if R\&D tax policy changes frequently, indicating the importance of a predictable policy framework (Westmore, 2013). Direct public support for business R\&D, which creates risks associated with "picking winners", has fallen in recent decades. However, direct support can also lead to positive outcomes, provided it is well designed and based on a competitive selection process.

Figure 21. Government support for business-sector R\&D is low in Japan

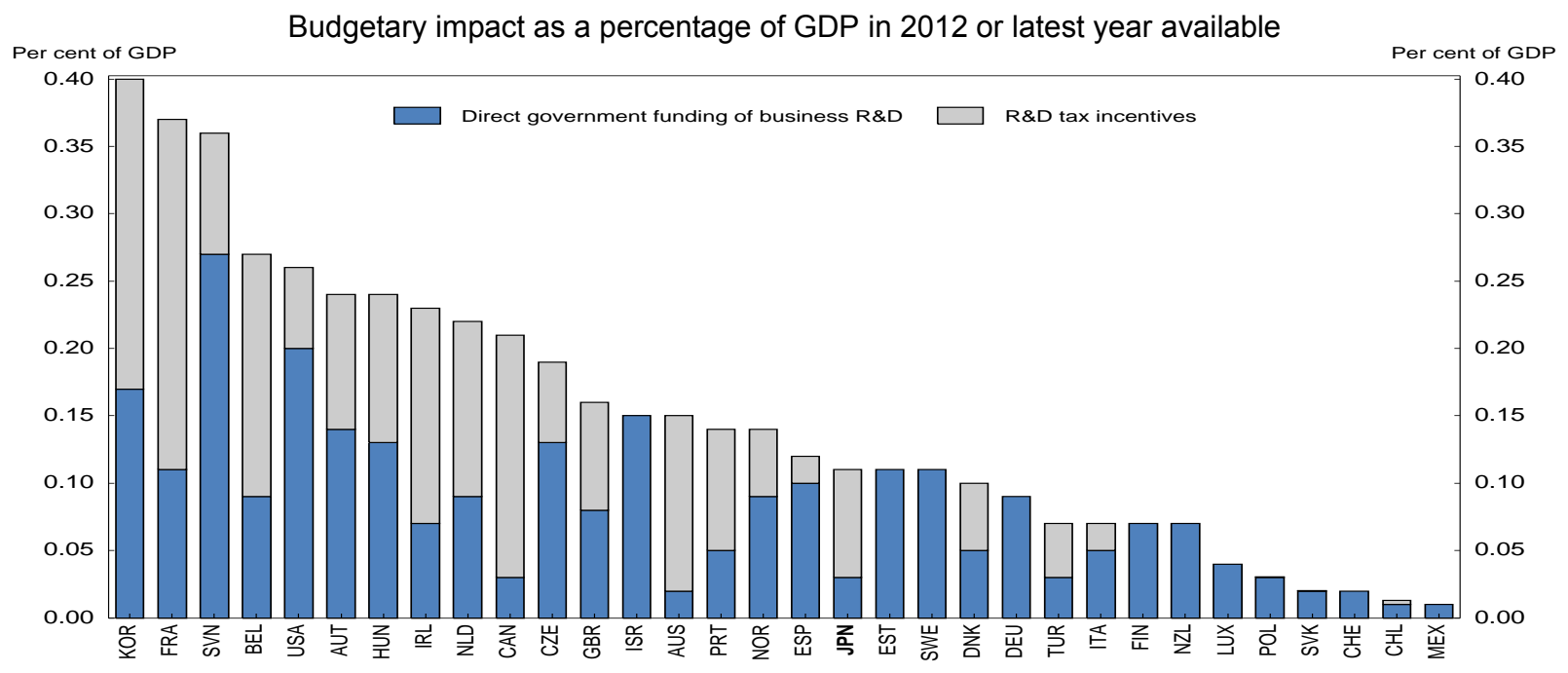

Source: OECD R\&D Tax Incentive Indicators; OECD National Accounts; OECD Main Science and Technology indicators.

Public R\&D support in Japan was relatively low at $0.1 \%$ of GDP in 2012 and is focused on tax incentives, which take the form of tax credits that allow firms to reduce their national corporate tax liability by up to $30 \%$. However, this approach favours large companies because they pay a higher corporate tax rate $(34.6 \%)$ than SMEs (23\%), which includes new start-ups that often do not have any profits. The R\&D support for large companies thus disadvantages new, more productive firms (Bravo-Biosca et al., 2012). Consequently, more generous R\&D tax credits are associated with a higher share of stagnant firms and a lower share of growing firms (Andrews and Criscuolo, 2013). Policies should aim at encouraging R\&D by smaller firms; enterprises with less than 250 workers accounted for only $4 \%$ of total business R\&D, compared to the OECD average of 33\% in 2011 (OECD, 2013d). To allow SMEs to benefit from the R\&D incentive, the tax credit could be made refundable (i.e. not limited by the firms' tax liability). In addition, increasing SMEs' interaction with government research institutes (GRIs) would help in this regard: only 1\% of SMEs collaborated with GRIs over 2002-04, compared to 9\% of large firms (OECD, 2008).

\section{Promoting start-ups and venture-capital backed firms}

SME start-ups, including venture businesses, play a major role in economic growth and innovation. Firms less than five years old, regardless of size, accounted for less than a fifth of total non-financial business employment but generated half of all new jobs over 2001-11 in the OECD area (OECD, 2013d). In Japan as well, firms aged less than five years old created around 2 million jobs between 2001 and 2006, in contrast to firms older than ten years, which reduced employment (Fukao and Kwon, 2011). The business start-up and closure rates in Japan averaged only 4.5\% over 2004-09, compared to $10 \%$ in the United States and the United Kingdom (Cabinet Secretariat, 2013). As a result, Japan's SME sector is dominated by old firms; three-quarters are more than ten years old compared to a share of less than half in most OECD countries (Figure 22). The Revitalisation Strategy set a target to raise the start-up and closure rates to $10 \%$. 
Figure 22. Small firms in Japan are relatively old

Share of small firms (less than 50 employees) by age (in years) over 2001-11

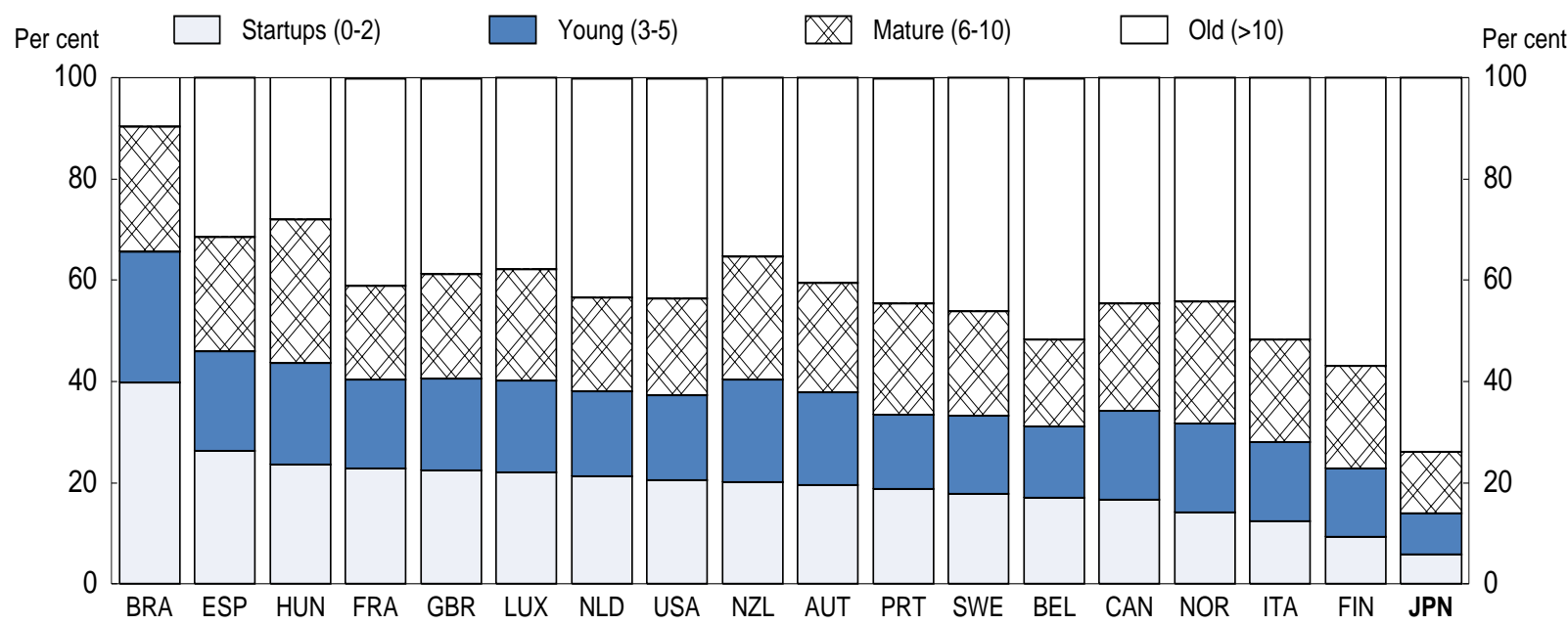

Source: Criscuolo et al. (2014).

\section{Venture capital investment is weak}

Venture capital investment in Japan is weak, reflecting the legacy of the corporate sector's reliance on debt rather equity finance. According to a government survey, entrepreneurs and their family and friends are the main sources of start-up financing. In addition, $25 \%$ of start-ups receive bank lending and $17 \%$ receive government loans and subsidies, but only $2 \%$ receive venture capital investment.

Venture capital investment declined markedly sharply over 2006-09 (Figure 23). Although it rebounded in 2013, it remains well below its earlier peaks. Moreover, $60 \%$ is invested in overseas companies. In addition, the number of firms receiving venture capital has fallen sharply from nearly 4000 in FY 2000 to 1000 in FY 2013. The level of venture capital investment in Japan is slightly below the OECD median and far behind such countries as Israel and the United States (Figure 24).

Figure 23. Trend of venture capital investment in Japan

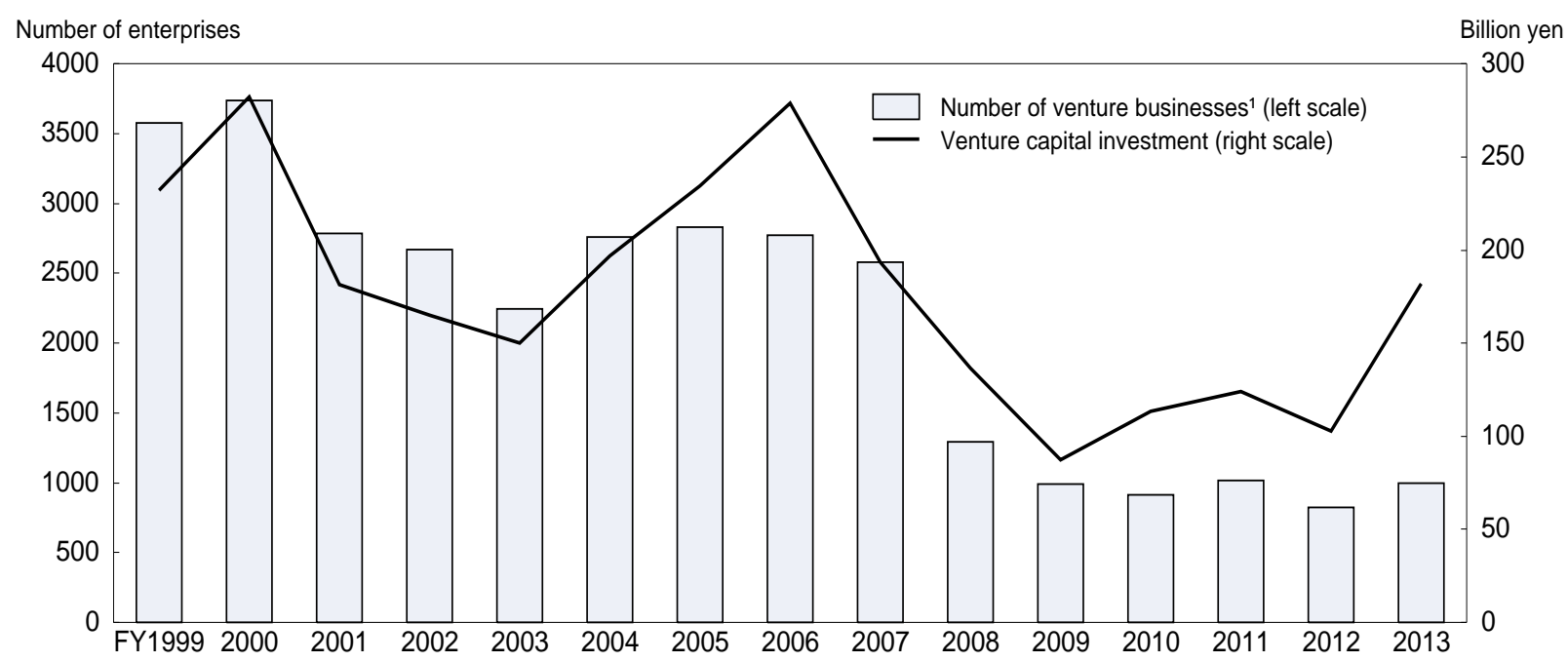

1. Number of firms receiving venture capital investment.

Source: Venture Enterprise Centre (2014). 
Figure 24. Venture capital investment as a share of GDP is relatively low in Japan

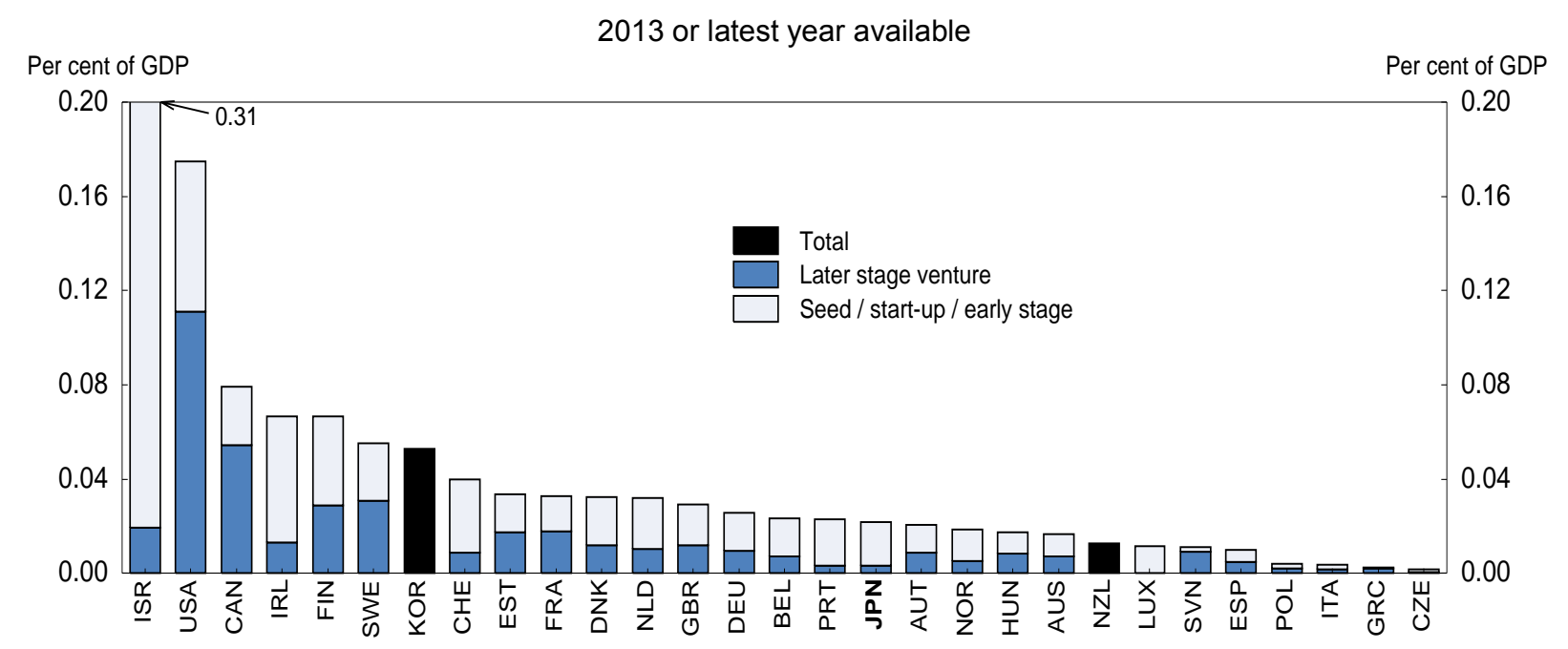

Source: OECD (2014f).

Among venture capital-backed firms at an early stage of development, financing is provided by private companies $(30 \%)$, public institutions $(18 \%)$, venture capital funds $(18 \%)$, banks $(17 \%)$ and business angels $(16 \%)$. The government believes that business angels should play a more prominent role in Japan as they do in many countries. In addition to supplying financing, they also provide mentoring and networks. This is particularly important in Japan, as less than the $12 \%$ of the Japanese believe that they have the skills needed to start a new business, the lowest among OECD countries (Global Entrepreneurship Monitor, 2015).

The largest investors in new venture capital funds are financial institutions (40.5\%) and the public sector $(17.4 \%)$ (Figure 25$)$. In contrast to the large government role, pension funds and academic institutions have not entered this market. In addition to the restraints on funding, the venture capital sector is also constrained by limited demands for funds. Japan has relatively few entrepreneurs, as less than a third of the working-age population views entrepreneurship as a good career choice, the lowest among OECD countries (Figure 26), reflecting in part a fear of failure. Employees with attractive business ideas and technologies tend to remain in large enterprises. Consequently, only $2.5 \%$ of the working-age population intends to start a business within three years, the lowest share in the OECD (Global Entrepreneurship Monitor, 2015).

\section{New government measures to promote venture capital}

The Revitalisation Strategy includes measures to promote start-ups and venture businesses. To enhance financing of ventures, a number of reforms have been introduced:

- The tax system for business angels is being made more user-friendly by streamlining application procedures. Angel investors receive an income tax deduction and losses from selling equities can be carried forward three years.

- Measures to promote crowd-funding were promulgated in May 2014, including a relaxation of entry requirements for operators of such platforms, although they must conduct checks on startups and provide information.

- Firms that invest in venture capital funds and which manage or provide technical support to venture capital-backed businesses will be designated as "Specified Investment Businesses", making them eligible for financial support from public financial institutions. 
- Up to $80 \%$ of investment by firms in venture capital funds can be counted as loss reserves and deductible expenses.

Figure 25. Breakdown of investors in newly-established venture capital funds in Japan ${ }^{1}$

1. Over the period FY 2010-12.

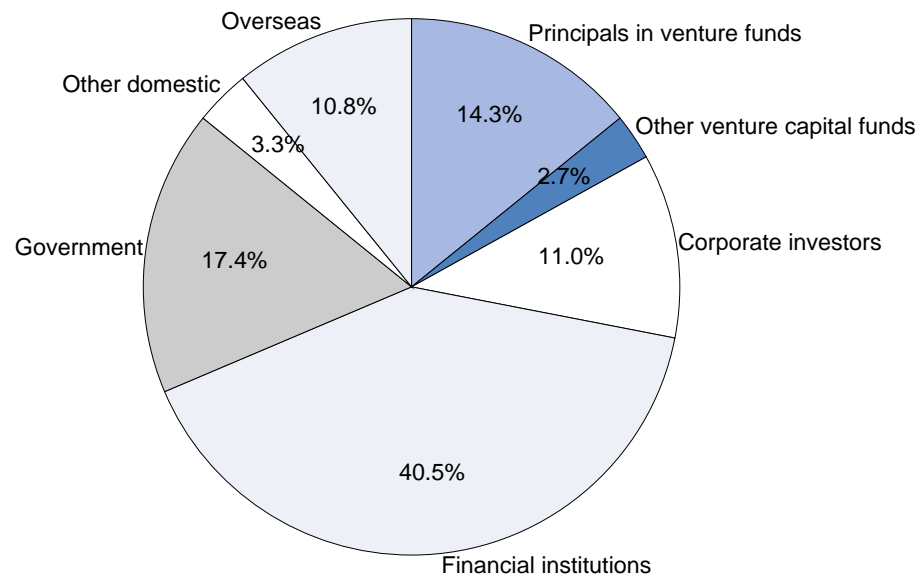

Source: Venture Enterprise Centre (2013).

Figure 26. Share of the population that views entrepreneurship as a good career choice is low in Japan

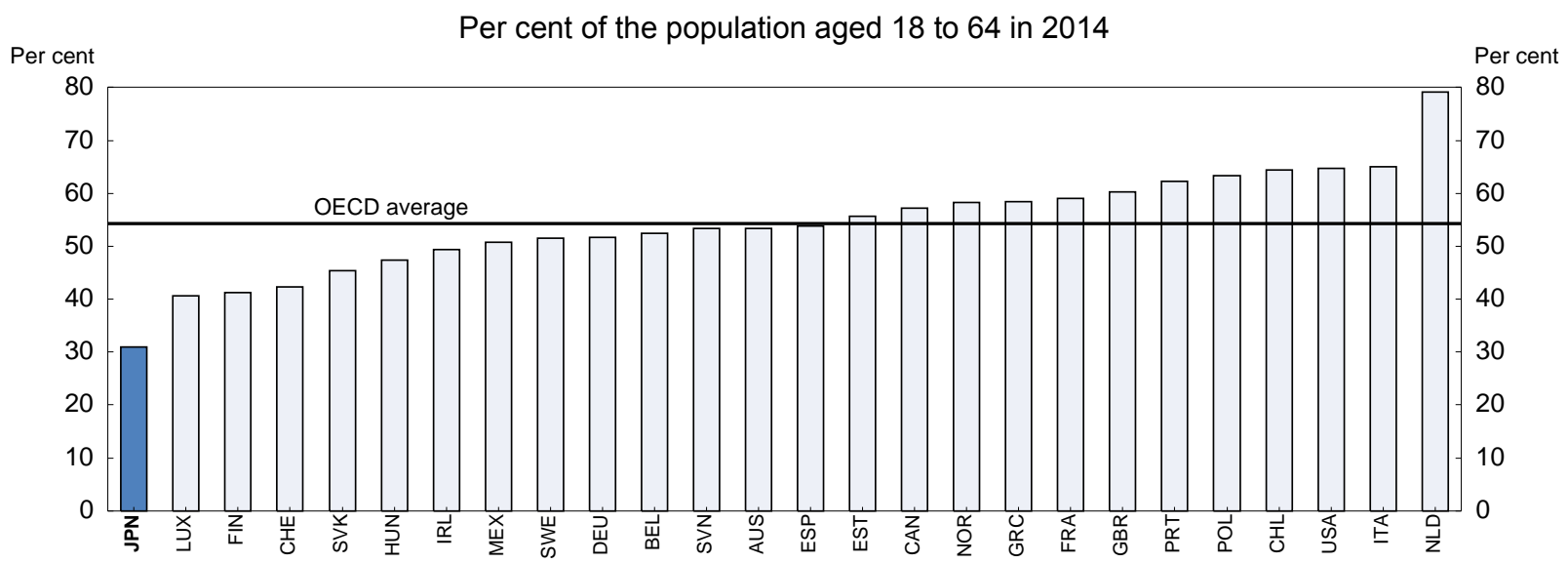

Source: Global Entrepreneurship Monitor (2015).

The government is also taking steps to improve the environment for venture capital-backed firms. First, it will nurture human resources for venture business by developing entrepreneurial education. Second, the personal guarantee system, which requires entrepreneurs to put their personal assets at risk in the case of failure, was revised. In some cases, personal guarantees will not be required, for instance if the business and personal assets of the business owner are clearly separated. Third, the government will promote investment by existing firms in venture business by supporting spin-offs and carve-outs. Finally, the 2014 version of the Revitalisation Strategy contains several steps to promote venture capital investment: $i$ ) the Venture Business Creation Council will be launched to promote connections between start-ups and larger firms; ii) government procurement from start-ups will be expanded; and iii) unemployment insurance will be provided to entrepreneurs who are not currently employed. 


\section{Policy directions to promote the venture business sector and start-ups}

Promoting start-ups, including venture-backed business, is a priority in light of their significant contribution to economic growth. The first priority is to address framework conditions by removing regulatory barriers, particularly in promising areas such as health and energy, and relaxing employment protection, as noted above. In addition, the government needs to encourage entrepreneurship, in part through education, to raise the firm creation rate. Indeed, the development of the venture capital industry cannot proceed more rapidly than the creation of attractive projects. Only $18 \%$ of the Japanese, the lowest in the OECD, agree that "school had helped to develop a sense of initiative and a sort of entrepreneurial attitude", compared to an OECD average of 52\% (OECD, 2013a). Moreover, education leaves students less prepared to become entrepreneurs. Less than $20 \%$ of Japanese think that their school education provided them the skills and know-how to run a business (Figure 27).

Figure 27. School education does not provide the skills for entrepreneurship in Japan

Per cent that agree that school education provided enabling skills and know-how to run a business (2012)

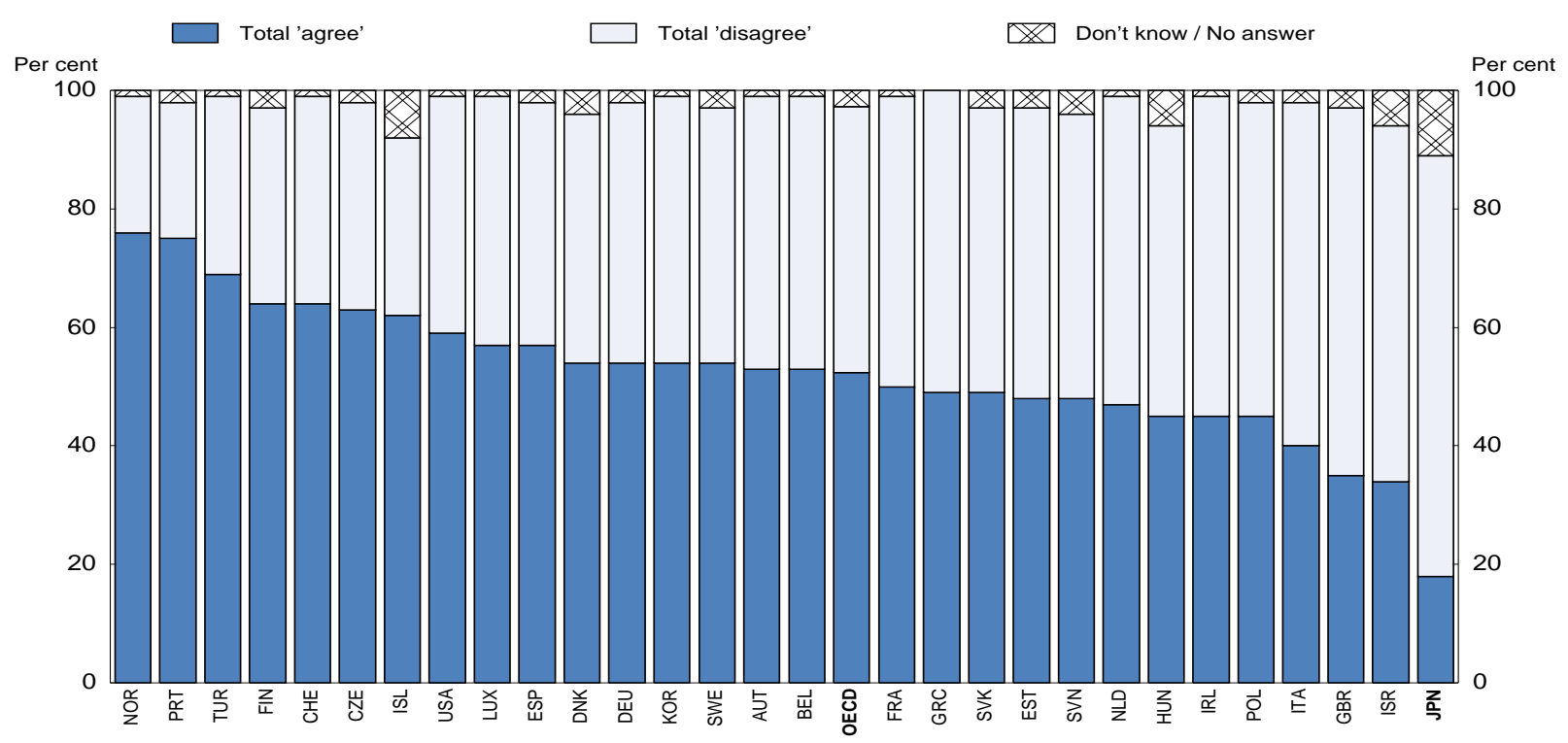

Source: OECD (2013a).

Recognising that entrepreneurship is a crucial skill for the $21^{\text {st }}$ century, the Ministry of Education, Culture, Sports, Science and Technology (MEXT) has launched programmes such as "Promotion of Global Entrepreneurs". However, these programmes are aimed at university and graduate students. Country experiences in this area suggest the following priorities. First, entrepreneurial skills need to be fostered in primary and secondary schools. Ireland, for example, has programmes for children from age ten. Second, entrepreneurship education should be broad in nature and go beyond career education. A recent EU study on entrepreneurship education focuses on creativity, entrepreneurial know-how, responsibility, risk-taking, problem solving, and team-working (European Commission, 2013). Third, entrepreneurial education requires inter-ministerial co-operation, as well as the support of public institutions and the private sector. For Japan, the OECD Tohoku School project, which focuses on helping students learn through practical hands-on experience, provides a good basis for developing entrepreneurial education.

Entrepreneurship would also be fostered by improving the environment for angel investors and large firms that finance and nurture start-ups. In addition, the stigma attached to failure should be reduced so that potential entrepreneurs are not dissuaded from launching start-ups by the lack of second chances. Indeed, the share of Japanese who agree that entrepreneurs who fail should have a second chance was the second 
lowest in the OECD in 2012 (OECD, 2013a). The government should promote an environment that allows entrepreneurs who fail to have additional opportunities to create ventures. In this regard, reducing the role of personal guarantees is welcome. Moreover, there should be channels through which the experience and knowledge of failed entrepreneurs can be used to benefit others.

The sources of funding for venture businesses should be diversified. In addition to a greater role for business angels, venture capital funds should be expanded to attract new investors. One important potential source is pension funds, which do not currently invest in venture capital. The Government Pension Investment Fund has decided to increase the proportion of equities in its portfolio from $25 \%$ to $50 \%$, equally split between domestic and foreign shares. While pension funds have to be cautious in investing in risky assets, some investment in venture capital "fund of funds" would help boost their returns. Greater links with academia could also encourage funding from universities as well. Another approach is to promote more venture capital investment from overseas. While around $10 \%$ of investment in newly established venture capital funds is from abroad, a more open environment for FDI (see above), could attract more foreign investment, given Japan's technological advantages in many areas.

The government plans to promote equity crowd-funding to raise money through relatively small donations from a large number of people, helping novice entrepreneurs obtain financing without red tape, thereby enabling them to save time and money. It thus creates a new channel for ordinary citizens to fund companies in exchange for shares in the business. By 2011, $\$ 1.5$ billion globally is estimated to have been raised, even though the legal and institutional framework is still in its initial stages (Jones and Kim, 2013). There are an estimated 700 platforms focusing on specific areas, primarily at an early stage of financing. However, crowd-funding's role as a source of start-up financing remains relatively small.

Japan should proceed carefully with its plan to make crowd-funding a complementary source of funding for entrepreneurs, as there is little analysis thus far of this new area of financial development. Most business angels spend considerable time and money on due diligence before investing, in contrast to equity crowd-funding, in which most investors are members of the general public. The lack of due diligence may increase the risk of fraud. In addition, entrepreneurs with poor proposals who are rejected by experienced investors after detailed due diligence might turn to equity crowd-funding, resulting in needless losses (Isenberg, 2012). From a company perspective, relying on equity crowd-funding would mean losing the guidance and networks provided by seasoned angel investors. In addition, an idea launched via the Internet is easily copied. For such reasons, equity-based crowd-funding is not currently allowed in most OECD countries. In the United States, businesses are allowed to sell up to $\$ 2$ million of unregistered securities through crowd-funding. In addition, individual investment is restricted to $\$ 10000$ or $10 \%$ of the investor's annual income - whichever is less. The need for investor protection depends on the amount of money raised. Crowd-funding that consists primarily of small amounts, thereby distributing risks widely, requires less regulation to protect investors, and offers a potentially important funding source for start-ups.

\section{Making the SME sector more dynamic}

SMEs accounted for $99.7 \%$ of registered firms, $70 \%$ of employment and more than $50 \%$ of value added in 2012 (SMEA, 2014a). The definition of SMEs varies by sector; in manufacturing, it includes firms with capital of 300 million yen or less or with fewer than 300 employees. Japan has a large number of SMEs per capita compared to other major economies (Shimizu, 2013). They form the backbone of the service sector and are a crucial part of the manufacturing and export supply chain. However, SMEs have long suffered from low productivity, weak profitability and high leverage (IMF, 2012a). The BoJ's diffusion index on business conditions for small firms has been in negative territory during most of the past two decades, running 20 to 30 points lower than for large firms. SMEs' debt-to-equity ratio has averaged more than $300 \%$ over $2000-10$, compared to $168 \%$ for large companies, making SMEs more vulnerable to shocks. Meanwhile, the net profit margin (adjusted by the capital ratio) is only $1.5 \%$ for SMEs, compared 
to $6.2 \%$ for large firms (Lam and Shin, 2012). Less than a third of firms with capital of less than 100 million yen $(\$ 85000)$ reported a profit in FY 2012. The number of SMEs has fallen from 4.8 million in 1999 to 3.8 million in 2012, reflecting in part the difficulty that ageing owners face in finding successors.

As SMEs rely heavily on domestic demand, they are especially vulnerable to economic and social changes (SMEA, 2014b). Indeed, only around 6000 SMEs $(0.2 \%$ of the total) are exporters and exports account for only $7 \%$ of sales in manufacturing SMEs compared to $28 \%$ in larger firms (EIU, 2010). The problems in the SME sector are linked to the weakness of services (Figure 9), given that more than threequarters of SMEs are in that sector. The 1963 Small and Medium Enterprise Basic Law, which had classified SMEs as a disadvantaged group, was revised in 1999 to define SMEs as a source of growth. Policies now have a dual focus: $i$ ) revitalisation of regional areas by maintaining employment and starting new businesses; and ii) realising Japan's growth potential by promoting new businesses and overseas business expansion (SMEA, 2014a). However, longstanding policies to prop up non-viable SMEs appear to have reached their limit. Accelerating the revitalisation of the SME sector is an objective of the Revitalisation Strategy.

\section{Financing SMEs}

SMEs' access to credit is constrained by their lack of collateral, short credit history and limited expertise in producing financial statements. Lending to SMEs is relatively risky, as information about small firms is costly to obtain and less reliable than for large companies and SMEs have a relatively high failure rate. These factors hinder lending to small firms. The longer a SMEs' history, the lower its borrowing cost (Uesugi, 2006). In Japan, lending to SMEs fell by 27\% between 1997 and 2013 (Figure 28), reducing its share from $63 \%$ of GDP to $50 \%$, in the context of generally sluggish output growth and deflation. Reduced lending lowered the debt-to-equity ratio of small firms with capital of between 10 and 100 million yen from 5.9 in 1997 to 2.2 in 2013. Nevertheless, the share of SMEs in commercial bank loans to firms was the fifth highest in the OECD at 68\% in 2012 (Panel B). The role of direct financing for small firms (with capital between 10 and 100 million yen) through issuing bonds and equities is negligible: they accounted for $2.5 \%$ and $0.3 \%$, respectively, of loans to SMEs.

Figure 28. Loans to small and medium-sized enterprises
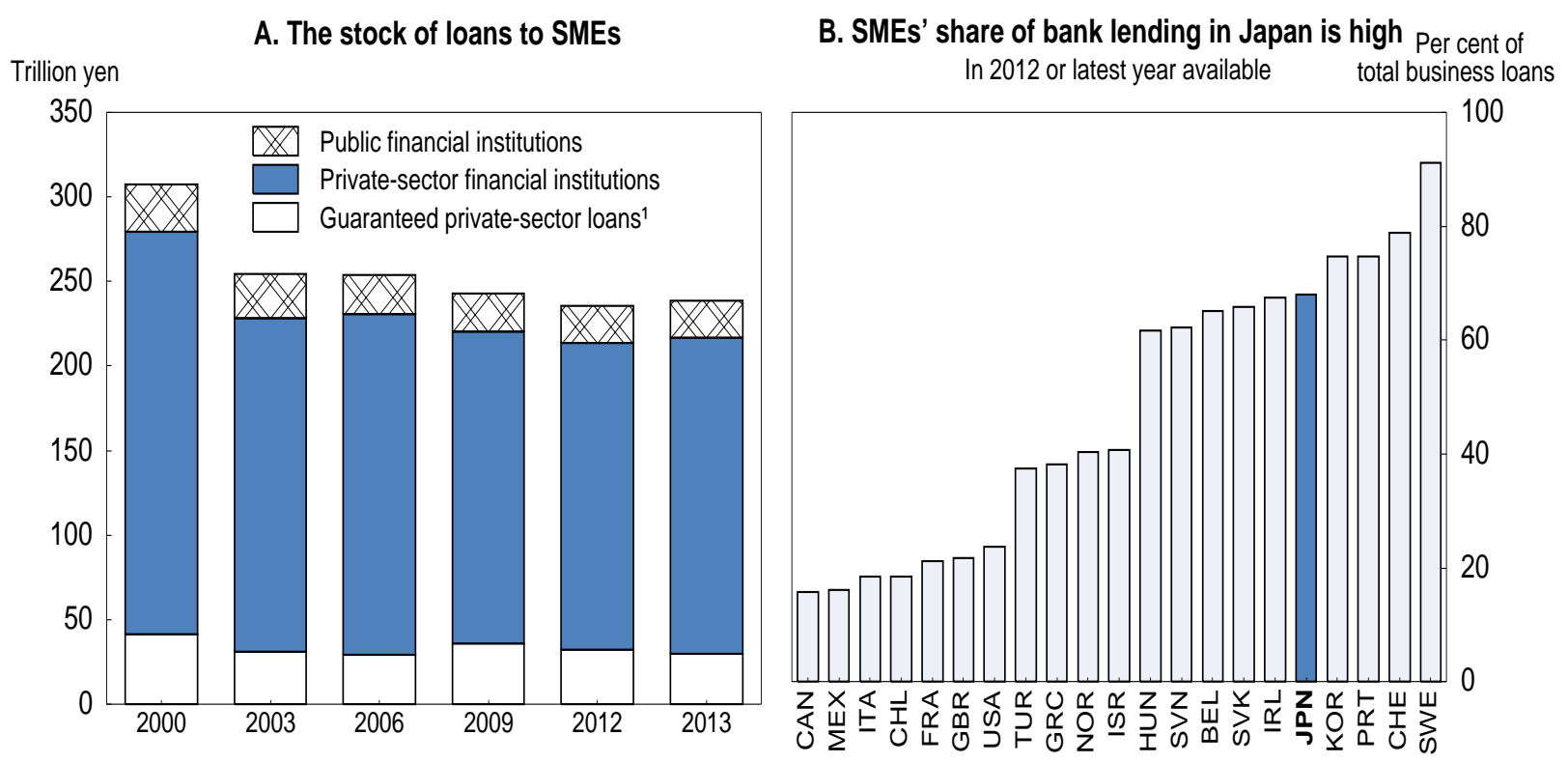

1. Guaranteed by the 52 credit guarantee corporations associated with local governments.

Source: Small and Medium Enterprise Association; OECD (2014e). 
The government provides about $10 \%$ of financing for SMEs, and its share rises to $20 \%$ once guarantees are included. Public support is delivered through a number of channels (Figure 29):

- The government provides loans at low interest rates directly through a public financial institution, the Japan Finance Corporation (JFC), which ensures safety net financing and supports business start-ups and overseas expansion (JFC, 2014). The JFC provides low, fixed-interest and longterm loans (half are for more than five years). JFC lending peaked at 12.0 trillion yen $(2.4 \%$ of GDP) in FY 2010 following the crisis, but fell to 6.5 trillion yen in FY 2013, according to the JFC's annual report.

- The JFC also provides indirect financing through another public institution, the Shoko Chukin Bank (SCB), which accounts for $3.7 \%$ of lending to SMEs on top of $5.1 \%$ by the JFC. The remaining $91 \%$ is divided between city banks $(31.0 \%)$, regional banks $(40.5 \%)$, Shinkin banks $(16.0 \%)$ and credit unions $(3.7 \%)$.

- Another important channel for SME support is public credit guarantees of private-sector loans to SMEs. Japan has 51 credit guarantee corporations (CGCs) that operate with the assistance of local governments. The CGCs, in turn, are insured by the JFC, which reimburses the CGCs in the case of default. In 2013, the default rate was $2.2 \%$ on guarantees. Credit guarantees have fallen since the 2008 global crisis but in FY 2013 the number (3.1 million) and amount (30 trillion yen, $12.5 \%$ of SME lending) remained high (Credit Guarantee Corporation, 2014). In 2013, 37.9\% of SMEs used public credit guarantees. SMEs pay credit guarantee fees, ranging from $0.39 \%$ to $2.2 \%$ depending on their creditworthiness, as evaluated by the Credit Risk Database (CRD). However, the guarantee fees received by the CGCs in FY 2011 were only about one-fifth of the insurance reimbursements from the JFC, which thus depends on subsidies from the central government (Yamori, 2014).

- The CRD also collects and shares SME business data, including financial, non-financial, and default information, which facilitates private lending. As of May 2014, 179 financial institutions belonged to the CRD (Credit Guarantee Corporation, 2014).

Figure 29. The framework of support for small and medium-sized enterprises

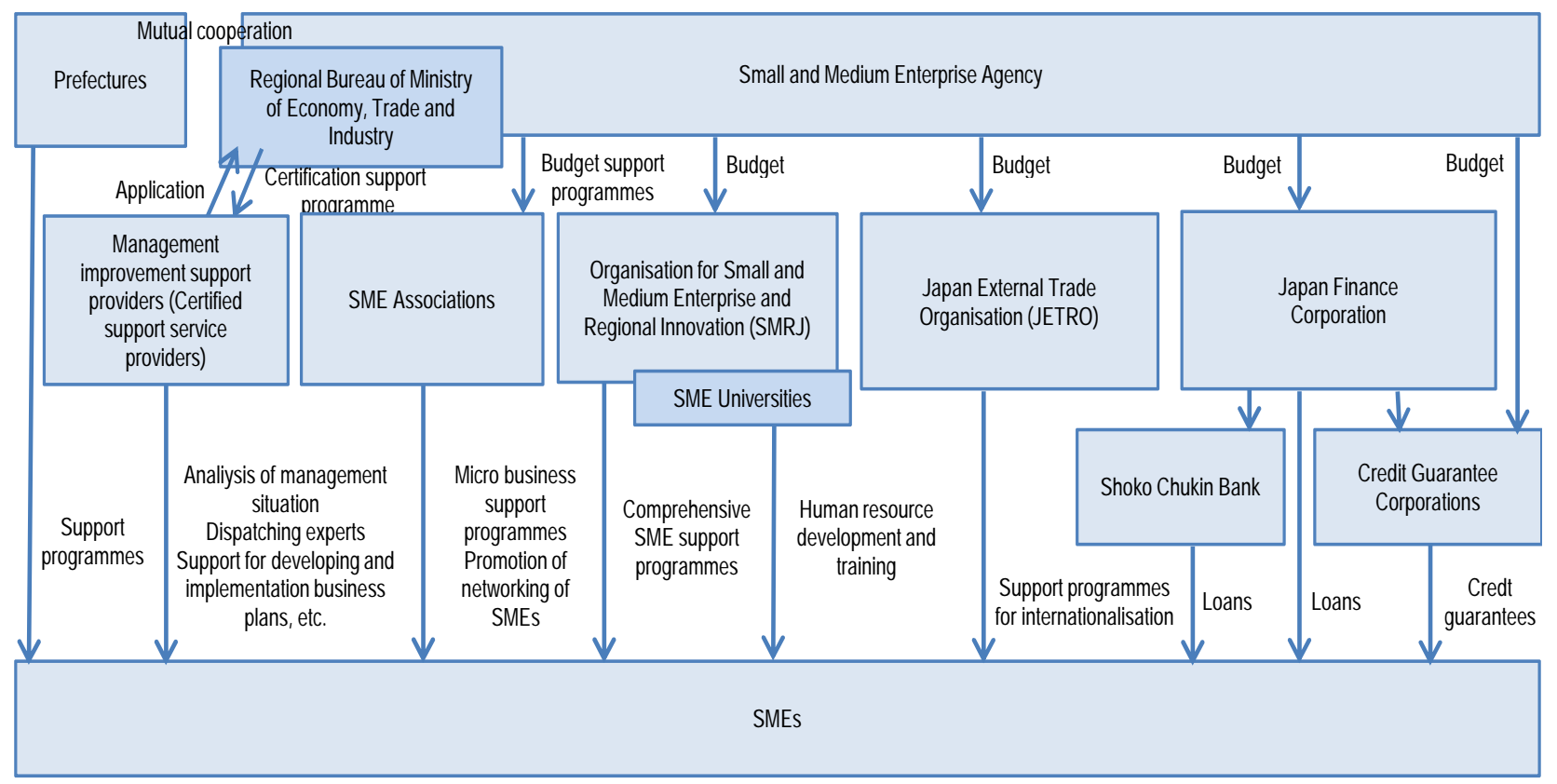

Source: Small and Medium Enterprise Agency (2014a). 
- $\quad$ The government also uses regulatory measures to support SME financing. For example, a 2008 law required financial institutions to review the terms of their loans to SMEs in response to requests by the borrowers, in particular by granting grace periods for payments of interest and principal (Yamori, 2014). The amended loans were not classified as nonperforming as long as the SMEs make credible restructuring plans (Endo, 2013 and Ono and Uesugi, 2014). While there was no legal penalty on banks that do not respond to SMEs' requests, banks must report their response to the authorities and publicly disclose it (Yamori et al., 2013). Of the more than 4.3 million loans for which SMEs requested modification, 97\% of them were approved by banks. The cumulative amount of modified loans reached 120 trillion yen (Ono and Uesugi, 2014). Although the law ended in April 2013, the Financial Services Agency continued to encourage financial institutions, through its inspections and supervisory processes, to modify the terms of their loans to SMEs (Endo, 2013). Capital adequacy regulations also have been modified since the 2008 crisis (Yamori et al., 2013). For example, the government does not require financial institutions that do not have overseas branches to include unrealised profits and losses for "other available-for-sale securities" in capital. This is to mitigate the adverse effect on SME funding caused by large fluctuations in unrealised profits and losses.

- The BoJ also supports SME financing. The "Measures to Support Strengthening the Foundations for Economic Growth" provides long-term funds at a low interest rate to private financial institutions for lending to SMEs with between 1 million and 10 million yen of capital.

\section{Problems associated with government intervention in SME financing}

High public support for SMEs has negative side effects. First, it hinders the development of marketbased financing. SMEs prefer government loans, as they carry low interest rates, while government credit guarantees reduce the burden of collateral and personal guarantees. Financial institutions are content to enjoy stable profits at low risk thanks to credit guarantees, thus reducing incentives to develop credit evaluation and risk management skills for SME lending and to closely monitor borrowers. The amount of guarantees in Japan is the highest in the OECD at 6.2\% of GDP in 2013 (Figure 30). In 2007, the government limited credit guarantees to $80 \%$ of the loan under the "responsibility-sharing system", making financial institutions liable for $20 \%$. However, following the 2008 crisis, the government launched an emergency scheme with $100 \%$ guarantees. Such guarantees apply to SMEs: $i$ ) less than five years old; ii) in structurally-depressed industries; and iii) located in areas affected by the 2011 earthquake. The guarantee coverage ratio should be reduced to about $60 \%$ - in line with international averages (IMF, 2012a).

Figure 30. Credit guarantees for SMEs in Japan are exceptionally high

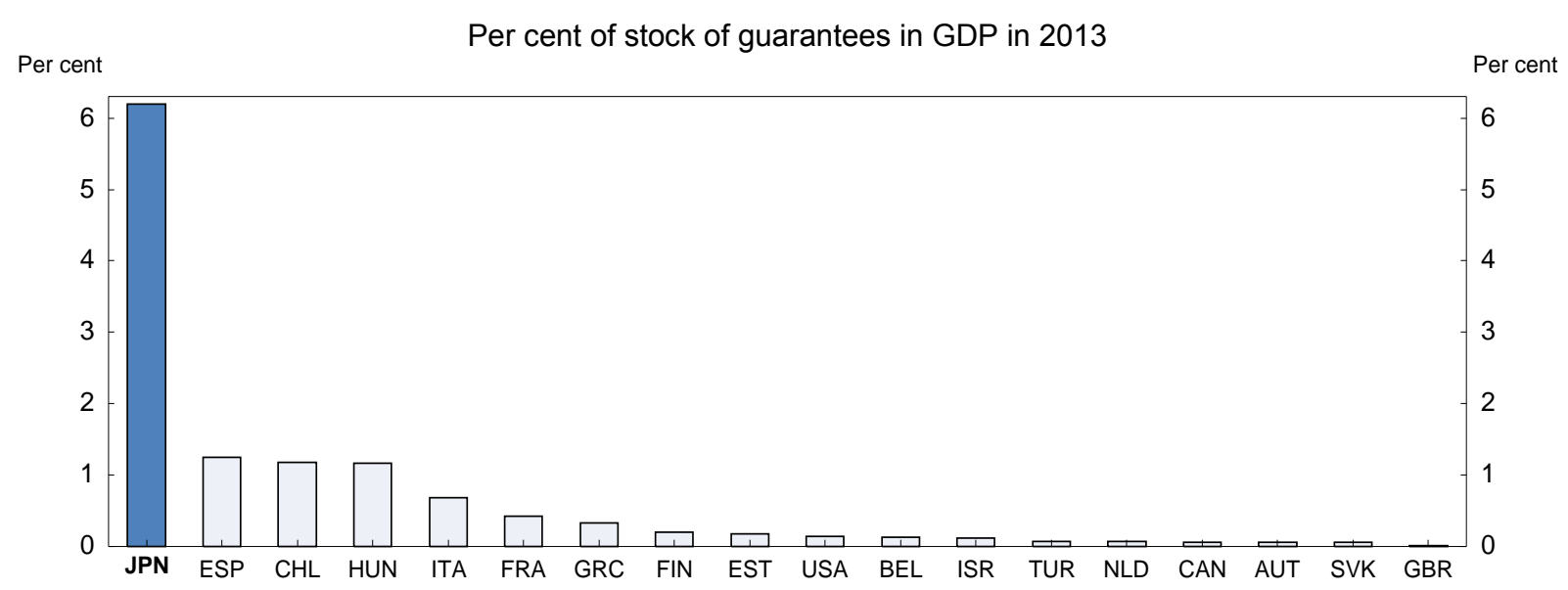

Source: OECD (2015a). 
The underdevelopment of market-based SME financing is reflected in the small share of "pure credit" loans, i.e. loans that do not depend on collateral and personal or public credit guarantees. In 2008, only $11.5 \%$ of SMEs had received "pure credit" loans, although this is more than in 2005 (Table 5).

Table 5. The share of SMEs relying on collateral and guarantees to receive loans

In per cent

\begin{tabular}{lrrrr}
\hline & 2005 & 2006 & 2007 & 2008 \\
\cline { 2 - 5 } Collateral & 51.5 & 49.7 & 44.3 & 40.3 \\
Personal guarantee by firms' representative & 50.6 & 52.0 & 63.5 & 59.4 \\
Personal guarantee by someone outside of firm & 18.1 & 17.5 & 12.1 & 10.5 \\
Public credit guarantees & 37.4 & 38.7 & 41.5 & 40.1 \\
None of the above (pure credit loans) & 5.2 & 4.3 & 7.8 & 11.5 \\
\hline
\end{tabular}

Source: Uesugi (2010).

Second, generous government support delays restructuring by keeping non-viable enterprises (socalled "zombie" firms) afloat (Caballero et al., 2008 and Kwon et al., 2009). Such support distorts resource allocation and limits access to finance by viable companies, thereby reducing Japan's potential growth. Indeed, firm exit and entry rates in Japan are only about one-third of those in other advanced countries (Lam and Shin, 2012). Japan introduced a Civil Rehabilitation Act in 2000 to promote restructuring, but by 2010, only 7700 SMEs ( $0.2 \%$ of all SMEs) had applied for it. The survival of non-viable firms also reflects support from financial institutions that wish to avoid recognising losses, as it would reduce profits and capital. Such an approach is facilitated by forbearance by financial supervisors in enforcing prudential regulations. Following the 2008 crisis, as noted above, the government did not require financial institutions to classify modified loans as non-performing, as long as the SME had a plan to normalise its situation in five to ten years, a relatively easy criterion to meet. In addition to reducing pressure on firms and lenders to restructure, such policies weaken the credibility of financial statements and the soundness of financial institutions. The Bank of Japan estimates that the change reduced the ratio of non-performing loans to total loans by 0.6 percentage points for large banks and 1.6 points for regional banks (Ono and Uesugi, 2014). In September 2014, the non-performing loan ratio was $1.1 \%$ for major banks and $2.6 \%$ for regional banks.

Banks' preference to avoid recognising losses and the practice of regulatory forbearance encourage the "evergreening" of non-viable firms, resting in a vicious cycle: the lack of restructuring by firms prevents efficient resource allocation, which in turn increases the risk of bad loans. One sign of evergreening is that the interest rate charged on loans to SMEs in Japan with low creditworthiness has been below the breakeven point of banks and above the rate for strong SMEs (Lam and Shin, 2012). In other words, the higher credit risk of weak SMEs is not reflected in interest rates due to government intervention. Another problem is the long duration of credit guarantees. In a survey of Aichi prefecture, two-thirds of firms had received guarantees for more than ten years (Yamori, 2014). In sum, government policies hinder restructuring. Even though the Japanese economy contracted sharply in 2008-09 and 2011, the number of bankruptcies has fallen since the crisis and by 2014 was a quarter below its 2007 level (Figure 31). In contrast, bankruptcies increased by an average of $66 \%$ in the OECD countries over 2007-12, with only four countries reporting declines (Panel B). 
Figure 31. The number of bankruptcies in Japan has fallen since 2008 despite two crises

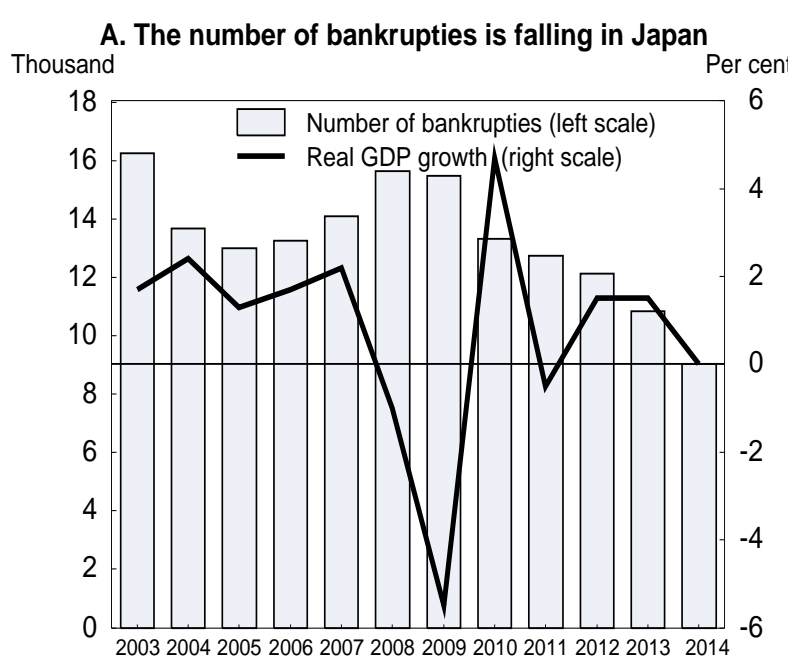

B. International comparison of number of bankrupties

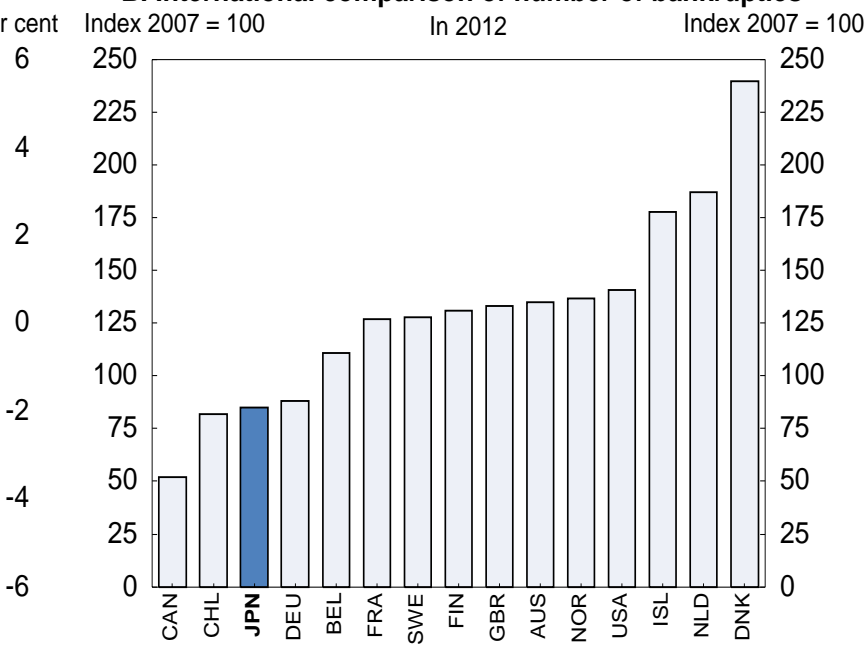

Source: OECD (2014f); OECD Economic Outlook Database.

Third, there is little evidence that government financial support improves SME performance. A 200712 study found that public support increased loan availability for SMEs but did not result in any significant increase in profitability compared to firms that did not receive benefits (Ono and Uesugi, 2014). Moreover, firms receiving public support recorded larger declines in employment. Another study showed that firms with public credit guarantees were more likely to be in deficit and took longer to repay loans than SMEs without such guarantees (Lam and Shin, 2012). Similar results have been found in other countries (Jones and Kim, 2014). Finally, high public support discourages small firms from growing and losing the benefits associated with SME status. The so-called "Peter Pan syndrome" is reflected in the fact that only $29 \%$ of Japan's largest 300 companies (by market capitalisation) have been created since the 1960 s, compared to $79 \%$ in the United States (Figure 32).

Figure 32. Large firms in Japan are relatively old

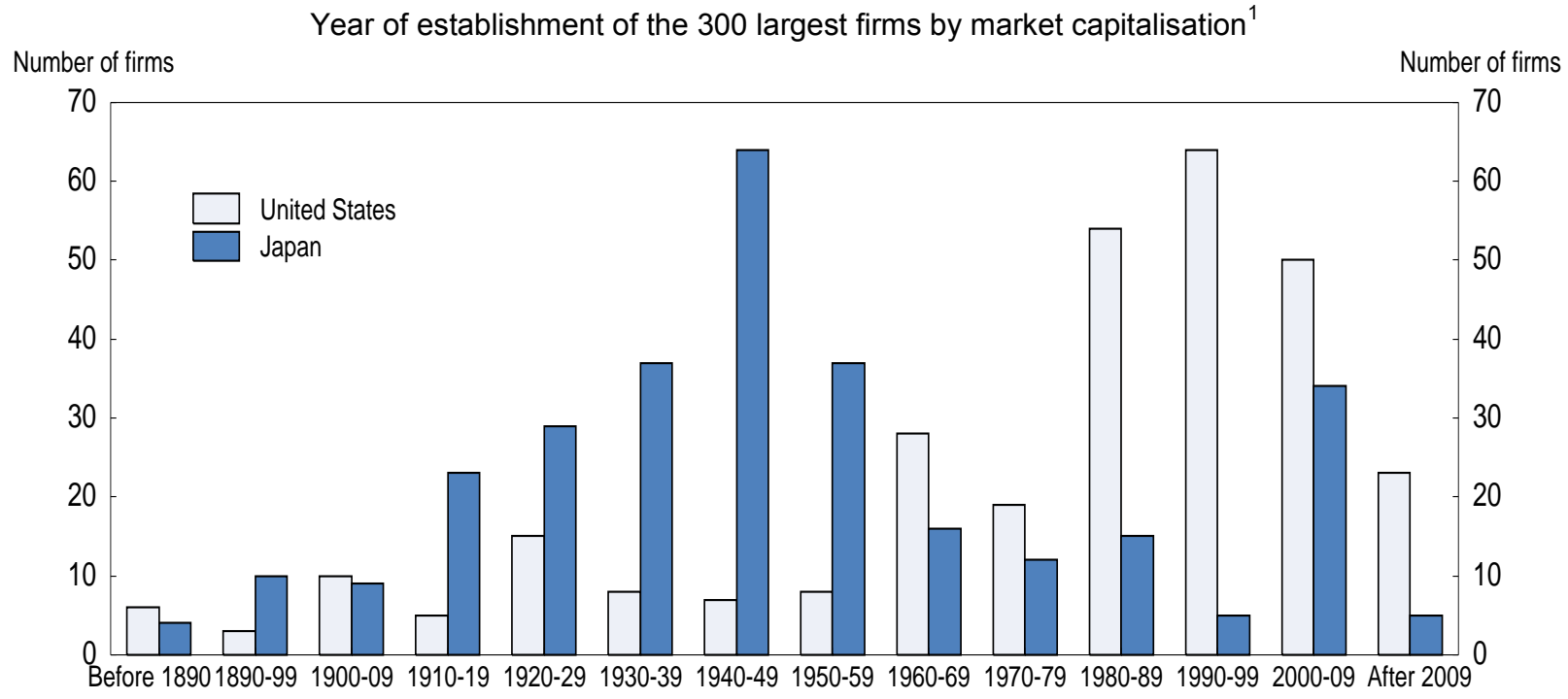

1. The increase in the number of Japanese firms established between 2000 and 2009 reflects the creation of a large number of holding companies during that decade.

Source: Thompson Reuters; OECD calculations. 
ECO/WKP(2015)79

\section{Directions for reform to improve government programmes for SMEs}

Arguably, government intervention should be limited to covering the SME financing gap - the difference between the amount of SME financing that would occur in the absence of market failures and the actual amount of financing - although this is difficult to estimate in practice. In Japan, however, the role of SME policies has expanded to promoting social cohesion and overcoming economic crises. Given its broad focus, SME support in Japan is generous compared with other OECD economies. Reducing it would help Japan address its fiscal problem while promoting restructuring.

Achieving the Revitalisation Strategy's goal of raising the business start-up and exit rates to $10 \%$ requires scaling back SME support and making it more market-friendly. In particular, the number of SME loans that are guaranteed should be reduced gradually and the coverage of credit guarantees should be set at $80 \%$ or less to force banks to actively monitor credit risks. Moreover, the cost of credit guarantees should be high enough to encourage strong SMEs to seek loans from private institutions rather than relying on public support. Even SMEs with high creditworthiness make large use of public financial institutions and credit guarantees (Minoya, 2012). When existing credit guarantees reach the end of their contract (usually seven years), they should not be renewed. This would allow greater focus on young SMEs, which face the most difficulty in obtaining loans.

Supervisors should not pressure financial institutions to modify loan contracts in response to requests from SMEs. Instead, the policy focus should shift from providing a safety net to cope with recent crises to promoting the restructuring of non-viable firms through efficient markets. To encourage such restructuring, financial institutions should be required to conduct regular credit reviews of SMEs, publicly announce the results, and prepare restructuring plans for non-viable firms, an approach adopted in Korea.

It is also essential to develop appropriate infrastructure for market-based SME financing in order to limit the negative effects of government intervention. Given that the cost of collecting and analysing information about SMEs exceeds the benefits for an individual financial institution, information should be collected and shared among institutions. While the CRD was intended to play such a role, timely credit information is still not available due to the reluctance of financial institutions to share information through credit registries. This reflects legal constraints and the lack of an identification system (IMF, 2012b). The government needs to reduce such obstacles to promote data sharing through the CRD.

In addition to information sharing, the government is encouraging direct relations between SMEs and financial institutions, so-called "relationship banking", to reduce the information asymmetry. In Japan, such relationships are already well developed: the average length of a SME's transactions with a bank is 32 years, compared to 22 in Germany, 16 in Italy, 14 in France and 11 in the United States (Uesugi, 2010). Long-term relationships in Japan partly reflect the age structure of firms (Figure 22). Such relationships, along with increased public support, helped to alleviate financing difficulties in the wake of the 2008 crisis. Indeed, only 461 firms (13\%) out of 3555 surveyed responded that financial institution(s) suddenly changed its (their) lending attitude. Of those firms, $43 \%$ reported that it was a large bank that changed their lending attitude, while only 9\% cited Shinkin banks, major credit suppliers to SMEs (Uesugi, 2010). Nevertheless, relationship banking should be improved to ensure that it can endure without the high levels of government support in Japan. It is essential to promote the financial health of the financial institutions that play a major role in SME financing, notably regional and Shinkin banks, which are financially weaker than the large city banks and have higher levels of non-performing loans.

Market-based financing for SMEs should be based on diverse methods. At present, loans backed by collateral, typically fixed assets, are widely used in Japan, although this is problematic as SMEs in general do not have sufficient fixed assets (IMF, 2012b). Moreover, company failure in the case of loans backed by personal guarantees creates a negative stigma that discourages entrepreneurship. The authorities have 


\section{ECO/WKP(2015)79}

encouraged asset-based financing based on inventory and current assets since the mid-2000s, but the use of such methods remains negligible. According to financial institutions and SMEs, the difficulty in assessing fair value has limited the use of these methods, especially in smaller financial institutions, such as regional banks and Shinkin Banks (IMF, 2012b). Therefore, it is necessary to train experts who can assess the value of non-fixed assets precisely and manage asset-based financing in both financial institutions and SMEs, while ensuring clear operating procedures to reduce regulatory risk.

Box 3. Main policy recommendations to enhance dynamism and innovation in Japan's business sector

\section{Strengthen competition and improve the allocation of resources}

- Upgrade corporate governance to increase pressure on management to act in shareholders' interests.

- Reduce product market regulation and promote labour market flexibility and mobility to promote the reallocation of resources in favour of innovative firms.

- Increase Japan's integration in the world economy by removing obstacles to inflows of foreign direct investment.

- Participate in high-level trade agreements, notably the Trans-Pacific Partnership and the Japan-EU Economic Partnership Agreement.

- Move to a more market-based agricultural system by measures such as reducing commodity-specific payments to farmers, accelerating the consolidation of farmland and reforming the role of agriculture cooperatives.

\section{Upgrade the innovation system}

- $\quad$ Strengthen the linkages between academia, the business sector and government research institutes.

- Integrate Japan in global R\&D networks and expand international collaboration in patenting.

Promote start-ups and venture capital-backed enterprises

- Improve the entrepreneurial climate by ensuring second chances and develop entrepreneurial education.

- Revitalise venture capital investment to promote firm creation and innovation.

Make the small and medium-sized enterprise sector more dynamic

- Reduce government support for SMEs to promote the restructuring of viable firms and the exit of non-viable ones.

- $\quad$ Develop market-based financing of SMEs. 


\section{BIBLIOGRAPHY}

Andrews, D. and A. de Serres (2012), "Intangible Assets, Resource Allocation and Growth: A Framework for Analysis", OECD Economics Department Working Papers, No. 989, OECD Publishing, Paris.

Andrews, D. and C. Criscuolo (2013), "Knowledge-based Capital, Innovation and Resource Allocation", OECD Economics Department Working Papers, No. 1046, OECD Publishing, Paris.

Andrews, D., C. Criscuolo and C. Menon (2014), "Do Resources Flow to Innovative Firms? Cross-country Evidence from Firm-level Data", OECD Economics Department Working Papers, No. 1127, OECD Publishing, Paris.

Aoyagi, C. and G. Ganelli (2014), "Unstash the Cash! Corporate Governance Reform in Japan”, IMF Working Papers, No. 14/138, Washington, DC.

Arnold, J., B. Brys, C. Heady, A. Johansson, C. Schwellnus and L. Vartia (2011), "Tax Policy for Economic Recovery and Growth", Economic Journal, Vol. 121.

Bravo-Biosca, A., C. Criscuolo and C. Menon (2012), "What Drives the Dynamics of Business Growth?", OECD Science, Technology and Industrial Policy Papers, No. 1, OECD Publishing, Paris.

Bouis, R., R. Duval and F. Murtin (2011), "The Policy and Institutional Drivers of Economic Growth Across OECD and Non-OECD Economies: New Evidence from Growth Regressions", OECD Economics Department Working Papers, No. 843, OECD Publishing, Paris.

Caballero, R., T. Hoshi and A. Kashyap (2008), "Zombie Lending and Depressed Restructuring in Japan", American Economic Review, Vol. 98, No. 5.

Cabinet Office (2009), Annual Report on the Japanese Economy and Public Finances, 2009, Government of Japan, Tokyo.

Çelik, S. and M. Isaksson (2013), "Institutional Investors and Ownership Engagement", OECD Journal: Financial Market Trends, Volume 2013/2.

Coleman, W. (2005), "Terms-of-Trade, Structural Transformation and Japan's Growth Slowdown", https://faculty.fuqua.duke.edu/ coleman/web/ColemanJapan.pdf.

Corrado, C., J. Haskel, C. Jona-Lasinio, and M. Iommi (2012), "Intangible Capital and Growth in Advanced Economies: Measurement Methods and Comparative Results", http://www.intaninvest.net.

Council of Experts Concerning the Corporate Governance Code (2014), Japan's Corporate Governance Code", http://www.fsa.go.jp/en/refer/councils/corporategovernance/20141226-1/01.pdf.

Credit Guarantee Corporation (2014), Credit Guarantee System in Japan.

Criscuolo, C., P. Gal and C. Menon (2014), "The Dynamics of Employment Growth: New Evidence from 18 Countries", OECD Science, Technology and Industry Policy Papers, No. 14, OECD Publishing, Paris.

Economist Intelligence Unit (EIU) (2010), “SMEs in Japan: A New Growth Driver?”, The Economist.

Endo, T. (2013), "Post-crisis Regulation of Financial Institutions in Japan”, ADBI-JFSA Joint Conference, Tokyo.

European Business Council in Japan (EBC), (2014), "The Japanese Market: Why Is It Difficult? What Suppresses FDI", Tokyo. 
European Commission (2013), "Entrepreneurship in the EU and Beyond", Flash Eurobarometer, Report 354, http://ec.europa.eu/public_opinion/flash/fl_354_en.pdf.

Expert Group of the Cabinet Office (2014), Report of the Expert Group Meeting on Foreign Direct Investment in Japan, Government of Japan.

Financial Services Agency (2014), Principles for Responsible Institutional Investors: “Japan's Stewardship Code", http://www.fsa.go.jp/en/refer/councils/stewardship/20140407.html.

Franzoni, C., G. Scellato, and P. Stephan (2012), "Foreign Born Scientists: Mobility Patterns for Sixteen Countries", NBER Working Papers, No. 18067.

Fujita, T. (2013), "Corporate Governance and the Rule of Soft Law", http://www.gcoe.j.utokyo.ac.jp/pdf/GCOESOFTLAW-2012-3.pdf

Fukao, K. and H. Kwon (2011), "The Key Drivers of Future Growth in Japan", http://www.accj.or.jp/en/news-a-media/press-releases/doc_view/86-the-key-drivers-of-future-growth-in-japan

Fukao, K. (2012), "Deindustrialisation in Japan and its Impact on Growth", Presentation for the Workshop "Is Deindustrialisation Inevitable? The Future of Manufacturing in Japan, Korea, Germany and France", Organised by the Fondation France-Japon de l'EHESS, Paris, 20-21 March.

Fukao, K., K. Ikeuchi, Y. Kim, H. Kwon, T. Makino and M. Takizawa (2014), “The Structural Causes of Japan's Lost Decades", http://www.worldklems.net/conferences/worldklems2014/worldklems2014_Fukao.pdf.

Global Competition Review (2013), Rating Enforcement Review, London.

Global Entrepreneurship Monitor (2015), Global Entrepreneurship Monitor 2014 Global Report.

IMF (2012a), Japan: Financial Sector Assessment Program - Technical Note on Credit Intermediation, IMF Country Report No. 12/262, September, Washington, DC.

IMF (2012b), Japan: Selected Issues, IMF Country Report No.12/209, August, Washington, DC.

Investor Impact (2014), “Japan's Stewardship Code: Implications for Investor Relations", http://investorimpact.com/wp/wp-content/uploads/2014/07/IR-Insight-July_E.pdf.

Isaksson, M. and S. Çelik (2013), "Who Cares? Corporate Governance in Today's Equity Markets", OECD Corporate Governance Working Papers, No. 8, OECD Publishing, Paris.

Isenberg, D. (2012), “The Road to Crowdfunding Hell”, Harvard Business Review, April.

Japanese Finance Corporation (2014), Annual Report, Tokyo (in Japanese).

Jaumotte, F. and N. Pain (2005), "From Ideas to Development: The Determinants of R\&D and Patenting", OECD Economics Department Working Papers, No. 457, OECD Publishing, Paris.

Jones, R. (2011), "Education Reform in Japan", OECD Economics Department Working Papers, No. 888, OECD Publishing, Paris.

Jones, R. and M. Kim (2014), "Promoting the Financing of SMEs and Start-ups in Korea", OECD Economic Department Working Papers, No. 1162, OECD Publishing, Paris.

Jones, R. and S. Kimura (2013), "Reforming Agriculture and Promoting Japan's Integration in the World Economy", OECD Economics Department Working Papers, No. 1053, OECD Publishing, Paris.

Kang, J. (2014), "Balance Sheet Repair and Corporate Investment in Japan", IMF Working Papers, No. $14 / 141$. 
Kinoshita, N. (2013), "Legal Background to the Low Profitability of Japanese Enterprises", Center on Japanese Economy and Business Working Paper Series, No. 316, Columbia University.

Koske, I., I. Wanner, R. Bitetti and O. Barbiero (2015), "The 2013 Update of the OECD Product Market Regulation Indicators: Policy Insights for OECD and non-OECD Countries", OECD Economics Department Working Papers, No. 1200, OECD Publishing, Paris.

Kuroda, H. (2013), "Overcoming Deflation: The Bank of Japan's Challenge", http://www.boj.or.jp/en/announcements/press/koen_2013/ko131010a.htm/.

Kwon, H., F. Narita and M. Narita (2009), "Resource Reallocation and Zombie Lending in Japan in the '90s", RIETI Discussion Paper Series, No. 09052, Tokyo.

Lam, W. and J. Shin (2012), "What Role Can Financial Policies Play in Revitalizing SMEs in Japan?", IMF Working Papers, WP/12/291, Washington, DC.

Liberal Democratic Party of Japan (2014), “Japan Revival Vision”, Japan Economic Revival Headquarters.

Martin, J. and S. Scarpetta (2012), "Employment Protection, Labour Reallocation and Productivity", De Economist.

Matsuo, Y. and J. Yamazaki (2014), “Japan's Special Zone Scheme: Third Time Lucky?”, Nikkei Asian Review, 20 May, http://asia.nikkei.com/print/article/31596.

Matsuura, T., H. Sato and R. Wakasugi (2011) "Temporary Workers, Permanent Workers, and International Trade: Evidence from Japanese Firm-Level Data", RIETI Discussion Paper Series, No. 11-E-030, Tokyo.

Ministry of Agriculture, Forestry and Fisheries (MAFF) (2010), 2010 Census of Agriculture and Forestry, Tokyo.

Ministry of Agriculture, Forestry and Fisheries (MAFF) (2012), Annual Report on Food, Agriculture and Rural Areas in FY 2011, Tokyo.

Ministry of Economy, Trade and Industry (2014), Ito Review of Competitiveness and Incentives for Sustainable Growth - Building Favorable Relationships between Companies and Investors; www.meti.go.jp/english/press/2014/pdf/0806_04b.pdf.

Ministry of Finance (2014), Annual Survey of Business Corporations, Tokyo (in Japanese).

Ministry of Health, Labour and Welfare (2014), Basic Survey on Skill Development 2013, Tokyo (in Japanese).

Minoya, A. (2012), "SME Finance in Japan: Experiences and Challenges", presentation, Bank of Japan.

Miyajima, H. (2012), "The Pros and Cons of Mandating the Appointment of Outside Directors: Based on New Empirical Testing", Research Institute of Economy, Trade and Industry, Tokyo.

Miyajima, H. (2013), "Reforming Japanese Corporate Management: Independent Audit Committees Should be Established", Research Institute of Economy, Trade and Industry, Tokyo.

Motohashi, K. (2013), "Innovation Policy Challenges for Japan: An Open and Global Strategy", Asie Visions 45, IFRI Center for Asian Studies, Paris.

Nakamura, Y. and M. Shibuya (1995), The Hollowing out Phenomenon in the Japanese Industry, Research Institute of International Trade and Industry, Tokyo.

Nezu, R. (2011), "Disturbing Deterioration in Terms of Trade in Asia", Institute for International Studies and Training, Tokyo, http://www.iist.or.jp/en-m/2011/0198-0806/. 
Nishimura, Y. (2013), Current Situation of University-Industry Collaboration and Technology Transfer in Japan: The Role of Intermediaries, http://www.eu-japan.eu/sites/eu-japan.eu/files/20130919Session2-1-Nishimura.pdf.

Ono, A. and I. Uesugi (2014), "SME Financing in Japan during the Global Financial Crisis: Evidence from Firm Surveys", Institute of Economic Research, Hitotsubashi University, Tokyo.

OECD (2008), Open Innovation in Global Networks, OECD Publishing, Paris.

OECD (2009), Evaluation of Agricultural Policy Reforms in Japan, OECD Publishing, Paris.

OECD (2011a), Board Practices: Incentives and Governing Risks, OECD Publishing, Paris

OECD (2011b), OECD Economic Survey of Japan, OECD Publishing, Paris.

OECD (2013a), Entrepreneurship at a Glance, OECD Publishing, Paris.

OECD (2013b), OECD Economic Survey of Japan, OECD Publishing, Paris.

OECD (2013c), OECD Science, Technology and Industry Scoreboard 2013, OECD Publishing, Paris.

OECD (2013d), PISA 2012 Results: What Students Know and Can Do (Volume I), OECD Publishing, Paris.

OECD (2013e), Supporting Investment in Knowledge Capital, Growth and Innovation, OECD Publishing, Paris.

OECD (2014a), Agricultural Policy Monitoring and Evaluation 2014, OECD Publishing, Paris.

OECD (2014b), Corporate Governance in Asia: Asian Roundtable on Corporate Governance, OECD Publishing, Paris.

OECD (2014c), Corporate Governance Yearbook, OECD Publishing, Paris.

OECD (2014d), Entrepreneurship at a Glance 2014, OECD Publishing, Paris.

OECD (2014e), Financing SMEs and Entrepreneurs 2014: An OECD Scoreboard, OECD publishing, Paris.

OECD (2014f), OECD Science, Technology and Industry Outlook 2014, OECD Publishing, Paris.

OECD (2014g), Services Trade Restrictiveness Index Regulatory Database, http://www.oecd.org/tad/services-trade/STRI_JPN.pdf.

OECD (2015a), Financing SMEs and Entrepreneurs 2015: An OECD Scoreboard, OECD Publishing, Paris.

OECD (2015b), OECD Economic Survey of Japan, OECD Publishing, Paris.

Okubo, T. (2014), "The Truth about Japan's Tokku Special Zones”, JBpress, 2 July, http://jbpress.ismedia.jp/articles/-/41109.

Prime Minister's Office (2007), Economic Effects of Regulatory Reform, Tokyo (in Japanese).

Saito, T. (2009), "Why Outside Directors in Japan are Not Prevalent?”, RIETI Report No.110, Tokyo.

Shimizu, K. (2013), "The Survival of Regional Banks and Small and Medium Enterprises", in Syncretism: The Politics of Economic Restructuring and System Reform in Japan, edited by K. Kushida, K. Shimizu and J. Oi, Walter H. Shorenstein Asia-Pacific Research Center, Stanford University.

Shinada, N. (2012), "Firms' Cash Holdings and Performance: Evidence from Japanese Corporate Finance", RIETI Discussion Paper Series, 12-E-031, Tokyo. 
Shirakawa, M. (2013), “Toward Strengthening the Competitiveness and Growth Potential of Japan's Economy", http://www.bis.org/review/r130315a.pdf.

Small and Medium Enterprise Agency (2014a), Japan's Policies for Small and Medium Enterprises, Tokyo.

Small and Medium Enterprise Agency (2014b), 2014 White Paper on Small and Medium Enterprises in Japan, Tokyo.

Squicciarini, M., H. Dernis and C. Criscuolo (2013), Measuring Patent Quality: Indicators of Technological and Economic Value, OECD Publishing, Paris.

Thangavelu, S. M. and C. Findlay (2011), "The Impact of Free Trade Agreements on Foreign Direct Investment in the Asia-Pacific Region", in ASEAN+1 FTAs and Global Value Chains in East Asia, Economic Research Institute for ASEAN and East Asia_Research Project Report 2010-29, edited by C. Findlay, Jakarta.

Ueda, R. (2014), "Corporate Governance in Japan: Developments in Listed Companies and Roles of Institutional Investors", Financial Research Center - Financial Services Agency.

Uesugi, I. (2006), SME Financing in Japan: What We Have Found, Research \& Review, 2006/01, Research Institute of Economy, Trade and Industry, Tokyo.

Uesugi, I. (2010), The Impact of International Financial Crises on SMEs: The Case of Japan, Hitotusbashi University, May.

Urata, S. (2005), "Japan Needs to Boost its Inward Foreign Direct Investment", Research Institute of Economy, Trade and Industry, Column 0132, July.

Venture Enterprise Centre (2013), Survey on Trends in Venture Capital Investment FY 2012, Tokyo.

Venture Enterprise Centre (2014), "The Result of Survey on Venture Capital Investment Trends in 2014 (Preliminary Report)", VEC Venture News No. 4.

Westmore, B. (2013), "R\&D, Patenting and Growth: The Role of Public Policy", OECD Economics Department Working Papers, No. 1047, OECD Publishing, Paris.

Wong, H. (2010), "Terms of Trade and Economic Growth in Japan and Korea: An Empirical Analysis", Empirical Economics, Vol. 38.

Yamori, N., K. Kondo, K. Tomimura, Y. Shindo and K. Takaku (2013), "Japanese Banking Regulations and SME Finance under the Global Financial Crisis", Japanese Journal of Monetary and Financial Economics, Vol. 1.

Yamori, N. (2014), "Japanese SMEs and the Credit Guarantee System after the Global Financial Crisis", Research Institute for Economics and Business Administration Discussion Paper Series, DP2014-26, Kobe.

Yashiro, N. (2013), "Strategic Zones to Revitalise the Japanese Economy?", East Asia Forum, 8 September, http://www.eastasiaforum.org/2013/09/08/strategic-zones-to-revitalise-the-japaneseeconomy/.

Yashiro, N. (2014), "Towards Responsive Regulations and Regulatory Coherence in ASEAN and East Asia: Deconstructing Effective and Efficient Regulatory Management Systems - Case for Japan", Economic Research Institute for ASEAN and East Asia, Jakarta. 